\title{
CERCETĂRI ARHEOLOGICE PREVENTIVE LA BALOMIRU DE CÂMP (JUD. ALBA)
}

\author{
EMIL DUMITRAŞCU, ALEXANDRU RAȚIU, ALEXANDRA DOLEA
}

PREVENTIVE ARCHAEOLOGICAL RESEARCH AT BALOMIRU DE CÂMP (ALBA COUNTY)

The archaeological research at Balomiru de Câmp (Şibot commune, Alba County) was undertaken in the framework of Autostrada National Research Project and was carried out in April-May 2012. The archaeological excavations led to the discovery of 13 archaeological complexes: a Roman building and its debris, 8 dwellings and 2 kilns from the Early Medieval period.

The Roman building represents an annex of a rural Villa type complex from the $2^{\text {nd }}-3^{\text {rd }} \mathrm{c}$. Due to intensive agricultural works and natural phenomena, the only preserved part of the building is the foundation. Out of the numerous findings discovered in the building's context we can mention a stamped ceramic lamp (FAVOR / F) and two tile fragments bearing the stamp of a local manufacturer (L S).

The medieval dwellings belong to a settlement from the $11^{\text {th }}-13^{\text {th }} \mathrm{c}$.; the structure's size cannot be accurately determined at this point of the investigations. The artefacts found in the dwellings are similar to other finds of early medieval period made along the Mureș Valley. Among them we can mention a large quantity of pottery (such as ceramic cauldrons, cooking pots and pot lids along with metal artefacts (an iron spur, an arrowhead, a spearhead etc.)

A particular feature of the site is represented by the wide spread network of modern draining ditches covering an important area of the investigation area, which overlap or cut in some cases the archaeological complexes making their stratigraphy difficult to interpret.

KEYWORDS: preventive archaeology, early medieval dwellings, the Mureș Valley, Early Medieval pottery CUVINTE CHEIE: arheologie preventivă, locuințe medievale timpurii, Valea Mureşului, ceramică medievală timpurie

\section{CONSIDERAȚII GENERALE}

Cercetările arheologice de la Balomiru de Câmp (com. Şibot, jud. Alba) au fost efectuate în cadrul Proiectului National de Cercetare „Autostrada”." Evaluarea teoretică a urmărit realizarea unei documentări de arhivă, cât mai complete, asupra diverselor categorii de surse istorico-arheologice (texte, fotografii, hărți, schiţe etc.) şi a referinţelor bibliografice relevante, dar şi a celor aerofotografice de arhivă, precum şi realizarea unor observaţii directe pe teren (în perimetrul vizat) pentru identificarea zonelor susceptibile să conţină vestigii arheologice, având în vedere semnalările anterioare.

Cercetările arheologice cu caracter preventiv, efectuate în primăvara anului 2012, în perioada martie-mai, au confirmat potenţialul arheologic, semnalat anterior, fiind identificate şi cercetate exhaustiv 13 complexe arheologice: o clădire din epoca romană, opt locuințe medievale, două cuptoare de exterior şi două şanțuri moderne ${ }^{2}$.

\footnotetext{
' În urma solicitării firmei STRABAG S.R.L. adresate Muzeului Național de Istorie a României, între cele douã părţi s-a încheiat un contract de prestări servicii în vederea efectuării cercetărilor arheologice preventive pe traseul viitoarei

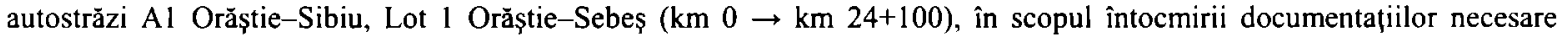
derulārii procedurii de descărcare de sarcină arheologică, în conformitate cu cerinţele legale aplicabile. (PI. I/2).

2 Cercetările au fost întreprinse de către o echipã a MNIR, în baza autorizaţiei nr. 36/12.03.2012 eliberată de MCPN-DPC. Cercetarea s-a desfăşurat între km $11+300$ şi km 11+370 ai viitoarei autostrăzi Al Orăştie-Sibiu, tronson Orăştie-Sebeş; vezi CCA 2013, 212-238, nr. 115, 116, 131-139.
} 
Obiectivele campaniei de cercetare arheologică preventivă în teren au constat în identificarea distribuţiei spaţiale, a elementele constitutive a tuturor vestigiilor, cât și recuperarea tuturor artefactelor şi ecofactelor descoperite, date fiind caracteristicile structurilor de habitat identificate (PI. II).

În cele ce urmează vom prezenta rezultatele cercetării arheologice preventive efectuate în perimetrul sus-menţionat realizate de către o echipă de arheologi din cadrul Muzeului Național de Istorie a României (MNIR)și al Muzeului Civilizației Dacice și Romane (MCDR).

\section{CADRUL FIZICO-GEOGRAFIC}

Localitatea Balomiru de Câmp este situată în lunca râului Mureş ${ }^{3}$. Începând din zona orașului Sebeş, situat la $17 \mathrm{~km}$ est de Balomiru de Câmp, Mureșul pierde contactul cu Podișul Transilvaniei, traversând o zonă, mărginită la nord de Munţii Apuseni, iar la sud de Munţii Sebeşului formând un culoar relativ îngust și o luncă. Acest culoar este o parte a aşa numitului „canal al Mureşului”, vechi braţ de mare, care făcea legătura între bazinul panonic şi cel transilvan ${ }^{4}$. În dreptul localității Balomiru de Câmp, râul Mureșul formează trei meandre în formă „de ac de păr”.

Pentru zona de referință, solul poate varia de la cel de mlaştină (mâl argilos) acoperit, după anotimp, de apă în cantitate mai mare sau mai mică, la cel de lăcovişte (foarte bogat în substanţe organice), sau la cel aluvionar fin (mâl), constituit din pături suprapuse şi îngroşat, după fiecare revărsare de apă, de nisipuri, pietrişuri, bolovănişuri ori îngrămădiri de blocuri colţuroase, în funcţie de treapta de relief în chestiune. Date fiind aceste caractere structurale compoziţia chimică a solului poate avea un conţinut diferit de calcar, argilă, silice, materii organice, săruri ${ }^{5}$.

Din punct de vedere administrativ, situl se află în limitele localității Balomiru de Câmp, comuna Șibot, fiind situat la $0,50 \mathrm{~km}$ SE față de sat și aproximativ $190 \mathrm{~m} \mathrm{~S}$ de DN 7 Sibiu - Deva, la poalele unui promontoriu cu o diferență de nivel de circa $40 \mathrm{~m} \mathrm{(PI.} \mathrm{I/2).} \mathrm{La} \mathrm{V} \mathrm{de} \mathrm{sit,} \mathrm{la} \mathrm{o} \mathrm{distanță} \mathrm{de}$ circa 200 m curge Pârâul Sărății, utilizat ca reper pentru numele punctului de cercetare arheologică, iar la aproximativ $1 \mathrm{~km} \mathrm{~N}$ curge râul Mureş. În partea de SE se află o mlaştină (cu o suprafață de circa $1600 \mathrm{mp}$ ) creată în jurul unui heleșteu, fapt ce contribuie la irigarea excesivă a zonei.

\section{SCURT ISTORIC AL CERCETĀRILOR DIN ZONA DE REFERINȚĀ}

Lunca Mureșului este o zonă foarte bogată în descoperiri arheologice care se încadrează majorității epocilor istorice. Cercetările prilejuite de construcția autostrăzii în zona dintre localitățile Sebeș și Orăștie au scos la iveală noi situri arheologice care au îmbogățit considerabil cunoașterea istoriei locale ${ }^{6}$.

Studiul hărţilor vechi ${ }^{7}$, în special a celor iosefine (1769-1773) şi francisco-iosefine (18061869) este de asemenea relevant pentru cunoaşterea aspectelor legate de amenajarea terenurilor din zonă în secolele XVIII-XIX, dar şi pentru localizarea unor obiective arheologice cu toponimie schimbată. Pornind de la toate aceste date, am putut face observații privind și rețeaua de drumuri și rute comerciale din zonă, informație relevantă în studiul analitic al descoperirilor arheologice.

În zona localităţii Şibot, erau semnalate, până în anul 2012, două staţiuni arheologice: o aşezare aparținând culturii Coţofeni (3500-2500 a. Chr.) şi elemente constructive din perioada romană

\footnotetext{
${ }^{3}$ Orghidan 1969,112

4 Orghidan 1969, 122

'Mihăilescu 1969, 236-237

'CCA 2013, 212-238, nr. 115, 116, 131-139

${ }^{7}$ Pentru studiul cartografic am folosit platforma open-source www.lazarus.elte.hu care conține hărți vechi geo-referențiate pentru întregul spațiu austro-ungar; hărțile pentru zona de referință se găsesc la link-ul http:/lazarus.elte.hu/hun/digkonyv/topo/200e/4146.jpg
} 
(cărămizi şi ţigle) localizate la ramificarea drumului de la gara Şibot spre satul Vinerea ${ }^{8}$. În cadrul campaniei de cercetări arheologice din cadrul aceluiași Proiect Național de Cercetare „Autostrada” au fost identificate și cercetate exhaustiv o așezare rurală cu necropolă și cartier meșteșugăresc ${ }^{9}(\mathrm{la} 1 \mathrm{~km}$ $\mathrm{V}$ de sit), dar și o importantă așezare medievală ${ }^{10}$.

Pe teritoriul localităţii Balomiru de Câmp este indicată și existența unei aşezări neolitice ${ }^{11}$ (cultura Starčevo-Criş, aproximativ mileniul VII a. Chr.). De asemenea, în arealul satului Balomiru de Câmp au fost identificate structuri de habitat aparținând culturii Coțofeni ${ }^{12}$. Listei descoperirilor din jurul localității Balomiru de Câmp se adaugă și câteva descoperiri datând din epoca bronzului ${ }^{13}$ și din prima epocă a fierului, culturile Gáva (secolele XIII-IX a. Chr.) și Basarabi (secolele IX-VII a. Chr. $)^{14}$.

Pentru epoca romană s-au descoperit fragmente ceramice sporadice și materiale de construcție $^{15}$. În vatra actuală de locuire a satului au fost identificate fragmente ceramice aparținând epocii arpadiene ${ }^{16}$ (secolele XI-XII).

\section{CONSIDERATุII DE ORDIN METODOLOGIC}

Având în vedere natura şi caracteristicile sitului, metodologia de lucru a fost adaptată şi structurată prin trei etape: documentarea și studiul istoric (evaluare teoretică), evaluarea de teren (diagnostic arheologic) și cercetarea arheologică propriu-zisă (săpătură arheologică preventivă).

Echipa de cercetare în teren, coordonată de dr. Adela Bâltâc în calitate de responsabil ştiinţific, a fost alcătuită din patru arheologi ${ }^{17}$, din cadrul MNIR, respectiv ai MCDR.

Cercetarea arheologică a început prin trasarea a opt secţiuni (cu lăţimea de $2,2 \mathrm{~m}$ şi lungimi variind între 6 şi $27 \mathrm{~m}$, care au avut scopul de a delimita situl în partea sa de SV. În momentul în care s-a observat o concentrare a descoperirilor de material arheologic s-a decis deschiderea unei unităţi de cercetare în suprafaţă (S 010), concomitent cu trasarea unei secţiuni magistrale cu o lungime de $93 \mathrm{~m}$ (S 009).

Analiza situaţiei stratigrafice din ce-a de-a doua secţiune de sondaj (S 014) a dus la deschiderea unor noi secţiuni de sondaj, orientate NE-SV, pentru a delimita situl şi în partea sa de NE. Astfel, a fost posibilă delimitarea zonei cu vestigii arheologice între $\mathrm{km} 11+350$ şi $11+410$, zonă investigată prin deschiderea unor unităţi de cercetare în suprafaţă. În funcţie de situaţiile înregistrate sa optat pentru decopertare cu mijloace mecanice (excavator cu cupă de taluz, cu lățimea de 2,20 m), pentru identificarea și săparea complexelor, s-a recurs exclusiv la săpătura manuală.

În ceea ce priveşte modalitatea de înregistrare a informaţiilor, au fost folosite metode descriptive uzuale în arheologie, respectiv însemnările de teren (carnet de săpătură, desene, fotografii, măsurători altimetrice şi topografice etc.). Înregistrarea grafică s-a constituit, atât din desene tehnice de planuri şi profile arheologice, cât şi din fotografii realizate în format digital. Înregistrarea stratigrafiei verticale s-a realizat contextual.

\footnotetext{
${ }^{8}$ Moga, Ciugudean 1995, 180-181, nr. 179; în acelaşi repertoriu sunt semnalate şi descoperiri sporadice, respectiv fragmente ceramice aparținând culturilor Cotofeni, Wietenberg, monede romane sau ceramică din perioada medievală.

${ }^{9}$ CCA 2013, 230-231, nr. 137

${ }^{10}$ CCA 2013, 229, nr. 136

" Popa 2011, 46; descoperire situată la circa 1 km nord de situl cercetat de noi, în punctul „Gura Vāii Cioarei”.

12 În punctele „Dupã Sat”, „Gura Vãii Cioarei”, „Satu Vechi”şi „Sāteşti”, vezi Popa 2011, 99.

13 În punctele „Gura Văii Cioarei”, „Sătești”, "După Sat”, „Cimitirul Ortodox”, ultimele trei aducând informații despre cultura Wietenberg, vezi Popa $2011,154,169,221$.

14 Î́n punctele „După Sat” şi „Satu vechi”, vezi Popa 2011, 266.

15 În punctele „Băltoci”, „După Sat”, „Gura Văii Cioarei” şi „Săteşti”, vezi Popa 2011, 353.

${ }^{16}$ Popa 2011, 404, 406

${ }^{17}$ Colectivul de cercetare a fost format din dr. Adela Bâltâc - responsabil, Alexandra Dolea, Emil Dumitraşcu, dr. Alexandru Raţiu (MNIR), dr. Gică Bāeştean (MCDR Deva).
} 
Pentru a avea o imagine cât mai sugestivă asupra stratigrafiei generale a sitului de la Balomiru de Câmp strategia iniţială de cercetare a presupus trasarea unor secţiuni magistrale de-a lungul axului autostrăzii, completate cu un profil perpendicular, în zona cu concentrare maximă a descoperirilor arheologice. Astfel, la nivel general, a fost stabilită următoarea succesiune stratigrafică, de sus în jos (PI. VIII):

1) Nivel de sedimente de culoare cafenie, afânate, cu resturi vegetale şi fragmente ceramice antrenate reprezentând stratul de arătură contemporană, situat de la nivelul actual de călcarc (0) până la cota de $-0,30 \mathrm{~m}$;

2) Nivel de sedimente de culoare neagră friabile, cu mult material tegular şi fragmente ceramice în compoziţie, de la cota de $-0,30 \mathrm{~m}$ până la $-0,65 / 0,70 \mathrm{~m}$;

3) Nivel de sedimente brun, lutos, fără urme de intervenţie antropică, de la cota de $-0,70 \mathrm{~m}$ sondat până la cota de $-1,10 \mathrm{~m}$;

4) Lentile de pietriş aluvionar; acestea apar în poziții diferite în compoziția nivelului 2.

În cadrul etapei de cercetare arheologică preventivă stratigrafia verticală a sitului, şi implicit complexele identificate, s-a făcut contextual şi anume au fost definite următoarele contexte arheologice:

Context 1 - nivelul vegetal actual, de culoare brun cenuşiu închis (negru), cu textură siltică (prăfoasă) nisipoasă, structură agregată datorată bioturbaţiei faunei, grad de compactare scăzut, frecvente rădăcini actuale şi urme de rădăcini, permeabil, cu foarte puţine materiale contemporane remaniate, rar şi materiale arheologice, în special fragmente tegulare, cu o depunere de $0,30 \mathrm{~m}$;

Context 2 - nivel antropic, discontinuu, sediment de culoare cenuşiu mediu, textură siltică nisipoasă, structură granulară, omogen, compact, conţine fragmente ceramice de mici dimensiuni, oase, pigmenţi de cărbune, fragmente tegulare în poziţie secundară, cu o depunere de $0,45 \mathrm{~m}$;

Context 3 - sediment de culoare neagră-cenuşie, textură siltică nisipoasă, structură granulară, relativ eterogenă, constituind umplutura complexelor arheologice din perioadă romană, cu o depunere de $0,25-0,50 \mathrm{~m}$;

Context 4 - sediment de culoare neagră-cenuşie, textură siltică nisipoasă, structură granulară, relativ eterogenă, constituind umplutura complexelor arheologice de perioadă medievală, conţine fragmente ceramice, oase, pigmenţi de cărbune, fragmente de vatră, cu o depunere de $0,55-0,80 \mathrm{~m}$;

Context 5 - sediment de culoare neagră-cenuşie, structură granulară, relativ eterogenă, constituind umplutura complexelor arheologice de perioadã modemă (şanţurile de desecare), conţine fragmente ceramice, oase, fragmente de ţigle romane, sticlā contemporană, cu o depunere de 0,20 $0,60 \mathrm{~m}$;

Context 6 - strat de argilă, de culoare galbenă, compact, omogen, permeabil, ce conţine carbonaţi, ce aparţine bazei terasei. Acesta reprezintã nivelul nominalizat de arheologi cu titulatura de steril arheologic, cu o depunere de $0,30 \mathrm{~m}$;

Context 7 - nivclul steril, sediment de culoare alb-gălbui, siltic, friabil, conţine carbonaţi şi este echivalent din punct de vedere arheologic contextului nr. 3, stratigrafic fiind situat sub acesta, cu o depunere de $0,20 \mathrm{~m}$.

Clădirea din epoca romană apare în anumite porțiuni încă din contextul 1 , cel vegetal, fapt ce a generat atenție sporită în acele zone. Lucrările agricole intense desfăşurate în perimetrul cercetat chiar până în toamna anului 2011 au distrus în bună măsură nivelul superior al clădirii din epoca romană (PI. V). Nivelul de amenajare al clădirii, cercetat în contextul 2, este observabil atât în plan, cât şi în profilul secţiunii magistrale S 009 (PI. VIII).

Celelalte complexe sunt observabile doar din contextul 2, în care au fost amenajate, fiind săpate până în solul steril. Această situaţie stratigrafică este, de asemenea, observată foarte clar în profilul magistral (PI. VIII).

Datorită fenomenelor geologice care au generat formarea văii Pârâul Sărăţii şi a pantelor ce-1 înconjoară, stratigrafia sitului a suferit anumite perturbații. Acest fenomen a fost documentat în secțiunile S 001-S 006, amplasate în extremitatea vestică a sitului, aproape de Pârâul Sărăţii. 
Descoperirile arheologice din cadrul sitului Balomiru de Câmp-Pârâul Sărății se încadrează în categoria complexelor de habitat rural, databile în două epoci distincte. Acestea au fost afectate de o rețea de canale de desecare, care suprapune și secționează majoritatea complexelor arheologice cercetate.

Primul context de locuire, din punct de vedere cronologic, este cel al clădirii romane ( $\mathrm{Cpl} 3$ ). Aceasta este construită din piatră legată cu pământ, dar nu oferă nici un indiciu referitor la funcţionalitatea sa. Materialul roman colectat este relativ puţin, singurul element notabil de datare fiind materialul tegular, găsit din abundenţă (PI. V).

Al doilea context de locuire este cel al locuinţelor semi-îngropate, databile în epoca medievală timpurie. Acestea sunt dispuse în jurul clădirii romane, una dintre ele (Cpl 6) chiar suprapunând colł̧ul de nord-est al acesteia (PI. IX). Locuinţele semi-adâncite au fost încadrate tipologic pe baza formei şi a elementelor constructive (cuptoare de interior și exterior), iar cronologic au fost încadrate pe baza materialului ceramic descoperit. Locuinţele medievale par să fie grupate în jurul clădirii romane, din structura acesteia fiind folosite piatră și tigle pentru diverse amenajări interioare, în special pentru cuptoare.

Materialul arheologic descoperit în contextul locuinţelor medievale este numeros, comparativ cu celelalte descoperiri din sit. Dintre acestea se remarcă prin număr fragmentele ceramice, nelipsind însă descoperiri de obiecte din metal, precum arme sau piese de echipament militar (PI. XX).

Şanțurile de desecare au afectat atât clădirea romană, cât și locuinţele medievale. Zona în care se află concentrate complexele arheologice în cadrul sitului este situată foarte aproape, la circa 70-100 $\mathrm{m}$, de o mlaştină. Nivelul 2 din stratigrafia sitului cuprinde urme consistente de inundaţie, materialul arheologic de mici dimensiuni fiind răspândit în tot acest nivel într-un mod uniform. Totodată, apariţia lentilelor din pietriş aluvionar, la diferite adâncimi şi în diferite puncte, demonstrează clar o situaţie caracteristică pentru o zonă inundabilă. În acest context, prezenţa şanţurilor moderne menţionate este pe deplin explicabilă. Orientarea generală a şanţurilor este NNE-SSV, cu mici variaţii. Materialul descoperit în umplutura acestor şanţuri variază de la materiale ceramice și de construcție romane la sticlă modernă sau contemporană.

Clădirea din epoca romană $(\mathrm{Cpl} 3)$ este constituită dintr-un zid perimetral din piatră de râu legată cu pământ, descoperit în elevaţie pe o singură asiză (PI. IX). Aceasta a fost cercetată în trei unităţi de săpătură: S 009, S 010 şi S 015 . Clădirea are formă dreptunghiulară; se păstrează doar zidul perimetral, fără compartimentări, cu grosime caracteristică clădirilor din epoca romană (circa $0,70 \mathrm{~m}$ ). Dimensiunile clădirii sunt de $20 \times 11 \mathrm{~m}$, iar orientarea acesteia este $\mathrm{N}-\mathrm{S}$.

Zidul perimetral este întrerupt în diferite porțiuni, motivele fiind multiple: o locuinţă semiadâncită din secol al XII-lea (Cpl 6), o rețea de şanţuri moderne sau numeroasele lucrări agricole contemporane (PI. IX). Tocmai din cauza acestor numeroase sincope în zidul clădirii, nu s-a putut documenta arheologic existența unei căi acces în interiorul acesteia.

În interiorul incintei formată de ziduri s-a descoperit un nivel compact şi consistent de dărâmătură format din ţigle de acoperiş, toate fragmentare şi, pe alocuri, fragmente de bâme carbonizate natural. Acest nivel de dărâmătură al acoperişului clădirii se află la acelaşi nivel cu nivelul pe care a fost ,zidită" asiza de pietre ce formează zidul perimetral. O eventuală podea nu a putut fi determinată arheologic, ci numai un nivel de pământ mai negru şi mai dens a fost observat sub acoperișul prăbuşit doar în interiorul zidului perimetral.

La cercetarea locuinței nr. $3(\mathrm{Cpl} \mathrm{6)}$, care secționează zidul de nord-est al clădirii, s-a putut observa faptul că nu există groapă de implantare a zidului, nici fundaţie. Astfel, se poate deduce că această unică asiză păstrată face parte dintr-un zid de susținere al unei suprastructuri din lemn, cu rol de fundație supraterană. Pentru spațiul interior al clădirii s-a observat lipsa oricărei compartimentări.

Stratigrafia clădirii este una foarte simplă, ilustrată elocvent și în profilul magistral al sitului (PI. VIII). Amenajarea zidurilor şi acoperişul prăbuşit se aflā la interferenţa nivelului vegetal (contextul 1) cu nivelul de cultură (contextul 2) în care se află amenajată clădirea şi în care sunt săpate 
locuinţcle semi-adâncite. Între cele două niveluri se interpun pe alocuri lentile de pietriş aluvionar. De menţionat că nivelul de cultură este compus dintr-un pământ negricios, posibil un nivel de băltire, anterior perioadei medievale.

Materialul arheologic descoperit în contextul clădirii este foarte sărac, compus în mare parte din fragmente tegulare, mici fragmente ceramice din epoca romană şi din obiecte din fier, piroane şi cuie (PI. XX). Din analiza ceramicii rezultă apartenenţa acestuia la perioada romană, secolele II-III p. Chr. Materialul tegular este format doar din țigle și olane, dintre acestea menționăm două fragmente de țiglă ștampilate cu ștampila L S (PI. XIX/49-50).

O parte a materialului roman descoperit in cadrul sitului provine din șanțurile moderne care traversau clădirea sau din contextele aferente complexelor medievale. Prezența ceramicii romane în contextele medievale se datorează faptului că gropile locuințelor semi-adâncite au fost săpate în apropierea clădirii romane.

Dintre artefactele descoperite în contextul sau în imediata apropiere a clădirii menționăm: o amforă de masă/ulcior amforoidal fragmentar (nr. cat. 1), un fragment de bol/farfurie din ceramică fină (nr. cat. 4), fragmente din ulcioare, fragmente de oale de bucătărie și mai multe fragmente dintr-un vas de provizii de dimensiuni mari (nr. cat. 13, Pl. XV/13).

În afara fragmentelor de vase ceramice menționăm și un fragment dintr-un opaiţ ştampilat (PI. XV/14). Din opaiț se păstrează doar rezervorul și o parte din bordură, iar din ștampilă se poate citi, pe primul registru, FAVO(R), şi litera $F(e c i t)$, pe registrul inferior. Literele A și V se află în ligatură, iar litera $\mathrm{R}$ este ilizibilă. Tipul opaițului nu se poate determina, dar tipul ștampilei este cunoscut în literatura de specialitate ca aparținând unui producător local, probabil din Pannonia ${ }^{18}$.

Materialul tegular este specific perioadei din care face parte clădirea. Toate piesele descoperite sunt fragmentare și constituie părți din țigle de acoperiş. Între acestea s-au descoperit două fragmente cu ștampile, diferite, dar cu aceeași marcă: două litere, imprimate separat, respectiv L și S. Ștampila este imprimată adânc în pasta crudă, nu are chenar, iar literele au dimensiunile de 3,7 × 1,7 cm.

În aşezarea și necropola de la Șibot ${ }^{19}$, cercetate în cadrul aceluiași proiect, s-au descoperit câteva analogii pentru aceste ștampile (PI. I/2). De asemenea ștampilele de tip L S sunt semnalate în alte trei situri romane de pe valea Mureșului: la Deva, Alba Iulia (Apulum) şi Micia ${ }^{20}$. O altă descoperire este semnalată la Cârjiţi (mun. Deva), dar ștampila apare sub forma I S, consideratã a fi o variantă a aceleiași ștampile ${ }^{21}$. După toate probabilitățile ștampila se referă la o marcă de producător civil, iar literele sunt inițiale pentru nomen gentile (Laberius, Laertius, Lucius etc.) și un cognomen (Sabinus, Saturninus, Silvanus etc.) ${ }^{22}$. Proveniența materialului este greu de precizat, unii autori oferă ca soluție figlina de la Micia ${ }^{23}$, pe când alții înclinā spre centrul urban și militar de la Apulum $^{24}$. Având în vedere lipsa de argumente solide ale autorilor citaţi, dar și aria de răspândire a ştampilei, se pot lua în considerare ambele teorii privind proveniența fără a exclude existența unui centru de producție necercetat încă.

Funcţionalitatea clădirii de epoca romană este incertă. Totuşi, în această privinţă, probabil că se pot elimina ipotezele de locuire, spaţiul interior al clădirii, dar şi forma şi dimensiunile acesteia, fiind improprii şi atipice unei funcţionalităţi de acest fel. Luând în considerație cercetările făcute in cazul analogiilor prezentate, putem presupune existența la Balomiru de Câmp-Pârâul Sărății a unei anexe ce a aparținut probabil unui complex rural de tip villa. Supoziția e susținută şi de periegheza în afara zonei cercetate la circa 30-40 de metri $\mathrm{N}$ de clădire, unde s-au descoperit numeroase fragmente tegulare, ccramică romană și piatră de râu folosită la construcții.

Analogii pentru acest tip de construcție s-au descoperit în Dacia Superior în conexiune cu complexe de tip villa. Cea mai apropiată analogie este cea de la Ciumăfaia ${ }^{25}$, unde chiar dacă

\footnotetext{
${ }^{18}$ Loeschcke 1919, 296; Alicu 1994, 20

${ }^{19}$ Informațic pentru care îi mulțumim, și pe această cale, colegei dr. Adela Bâltâc.

${ }^{20}$ IDR III $/ 3,202$, Ia-Ic

${ }^{21}$ IDR III/3, 43. Nu existã fotografii sau desene ale ştampilei, se menționează însă că litera I este greu lizibilă, deci ar putea fi de fapt litera $\mathrm{L}$.

${ }^{22}$ IDR III/3, 202

${ }^{23}$ Floca et alii 1974,111

24 Branga 1980, 145-146, fig. 85-86

${ }^{25}$ Mitrofan 1973, 133-135, fig. 4
} 
dimensiunile sunt mai mici, proporțiile şi forma clădirii sunt foarte asemănătoare. Mai amintim în același sens descoperirile de la Apahida ${ }^{26}$ (jud. Cluj), Hobița-Grădişte ${ }^{27}$ (jud. Hunedoara) sau cele două descoperiri de la Apoldu de Sus, din punctele Curtea Velii ${ }^{28}$ și Levejoare ${ }^{29}$. În toate aceste cazuri clădirea mare, nepartajată, a fost considerată fie grajd/hambar, fie o curte îngrădită (în cazurile unde nu s-a descoperit acoperișul prăbuşit în interiorul clădirii).

Descoperirea clādirii din epoca romană de la Balomiru de Câmp se situează firesc în peisajul urbanistic și rural al Daciei romane. În apropierea clădirii a fost, de-a lungul timpului, semnalat și cercetat un important drum roman ${ }^{30}$. Valea Mureșului și drumul construit aici de romani, probabil în timpul împăratului Traian, a constituit principala cale de acces spre Pannonia dinspre provincia Dacia. De la Apulum spre vest pornește, pe malul drept al Mureşului, un drum care se bifurcă $\bar{a}^{31}$ imediat după castrul de la Cigmău (Germisara?). O arteră merge spre capitala provinciei, Ulpia Traiana și ajunge la Dunăre la Aque, iar o a doua arteră se îndreaptă spre Pannonia prin Micia - Vețel ${ }^{32}$. În cadrul aşezării rurale de la Șibot - „În Obrej ${ }^{, 33}$ s-a cercetat, printre altele, şi o porțiune dintr-un drum roman de piatră care era orientat aproximativ E-V și trecea foarte probabil la mică distanță de clădirea romană de la Balomiru de Câmp. Desigur, acest drum se află pe malul drept al Mureșului, dar nu este exclus ca rețeaua de drumuri din perioada antică să fi acoperit ambele laturi ale acestui râu.

Clădirea romană de la Balomiru de Câmp este situată în proximitatea acestui drum, la jumătatea distanței dintre Apulum şi Cigmău. Cum am menţionat anterior, la circa $1 \mathrm{~km}$ în aval de sit s-a descoperit o așezare rurală importantă din epoca romană (PI. I/2). În aceste condiții putem concluziona că descoperirea de epocă romană de la Balomiru de Câmp face parte, cel mai probabil, dintr-o aşezare rurală de tip villa. Aceasta ar fi fost amplasată (cum era și firesc) în apropierea unui drum și a unei așezări, aşa cum sfătuiau şi agronomii romani ${ }^{34}$.

Complexele din epoca medievală cuprinde opt locuințe (dintre care trei distruse) și două cuptorare de tip ,gospodăresc”, de exterior. Faptul că aceste complexe aveau instalaţie de combustie, dar și forma, în general rectangulară, și dimensiunile destul de mari au condus la concluzia că avem de a face cu locuințe ${ }^{35}$. Din cauza faptului că partea superioară a acestora a fost distrusă de lucrările agricole sau de amenajările contemporane, nu au fost identificate intrările în incinte, situație întâlnită și în alte așezări medievale ${ }^{36}$. Nu a fost surprinsă o relație stratigrafică a cuptorului țărănesc și locuințele semi-adâncite, dar materialul ceramic descoperit în contextul acestuia îl situează cronologic în aceeaşi perioadă.

Datarea complexelor s-a fãcut pe baza materialului ceramic descoperit în abundență în contextele arheologice aferente complexelor. Cel mai important element de datare l-au constituit căldările de lut, descoperite în număr mare, care ne-au permis o încadrare cronologică în perioada secolelor XII-XIII ${ }^{37}$.

Locuința 1 (Cpl 1) este o locuinţă semi-adâncită, situată în suprafața S 011, care a fost inițial identificatā într-o secțiune de diagnostic arheologic în campania 2011 (PI. X). Forma locuinţei în plan este trapezoidală, orientarea NE-SV, iar adâncimea maximă a gropii locuinței este de $0,20 \mathrm{~m}$, de la nivelul la care a fost observată, iar dimensiunile generale ale complexului sunt $3,95 \times 2,58 \mathrm{~m}$, având o suprafață de circa $10,2 \mathrm{~m}^{2}$. În urma cercetării, s-a stabilit că această locuinţă dispunea de cuptor de

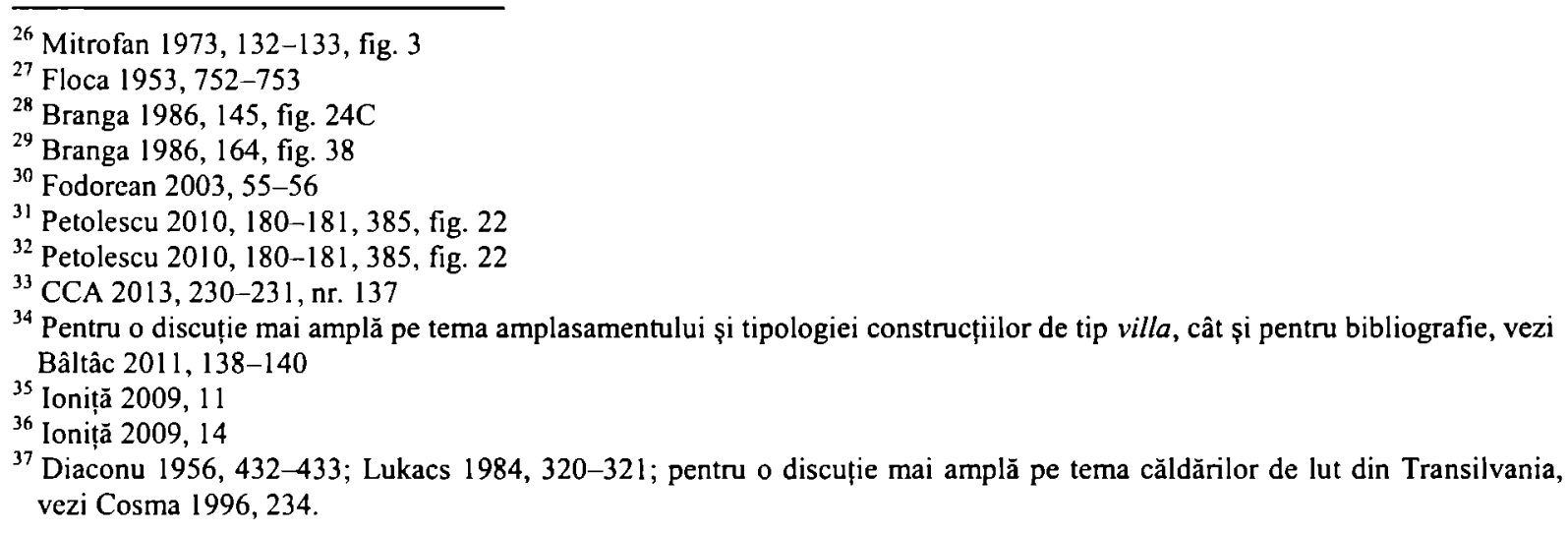


interior în zona de nord-est, iar în colțul de vest au fost identificate resturile unei vetre, fapt observabil şi la alte complexe din cadrul acestui sit.

Materialul descoperit este format din fragmente ceramice ce au aparținut unor vase precum căldări, vase de provizii, un fragment de fund de vas cu marcă de olar (nr. cat. 17), oale (nr. cat. 36, 41 și 42), străchini (nr. cat. 15, 16) şi fragmente osteologice animale. În contextul locuinței a fost descoperit și un vas roman (oală, nr. cat. 9)

Locuința 2 (Cpl 5) a fost cercetată în suprafața S 015, dar forma şi dimensiunile ei nu au putut fi stabilite. Complexul a fost distrus în mare parte de şanţurile de desecare ce traversau longitudinal şi latitudinal situl arheologic; în acest punct șanțurile moderne/contemporane se intersectau.

Materialul ceramic este format din: fragmente de oale (nr. cat. 27, 37), un capac - fragmentar (nr. cat. 47), dar şi ceramică romană - un fund de vas (nr. cat. 8) și un fragment de bol (nr. cat. 5).

Locuința $3(\mathrm{Cpl} 6)$, cercetată în S 010 şi parţial în S 009, suprapune colţul de nord-est al clădirii romane (PI. XII). Groapa locuinței a fost săpată într-un sediment negricios, semi-compact (context 2), iar umplutura gropii (context 4) este de culoare brun-negricioasă, dar mai puţin compactă, fiind evidentă legătura dintre aceasta și întreruperea zidului clădirii romane (context 3 ). Locuinţa are forma unui patrulater cu colţurile rotunjite, iar în colţul de nord-est a fost amenajat cuptorul. Acesta avea o formă circulară, cu o calotă semisferică în partea superioară, ulterior prăbuşită în interior. Vatra cuptorului este constituită dintr-o lutuială pe pământ, fără substruç̧ie şi are un diametru maxim de 0,8 m. Adâncimea maximă a gropii locuinţei este de $0,58 \mathrm{~m}$, de la nivelul de amenajare a clădirii romane, iar dimensiunile generale ale complexului sunt $2,72 \times 2,68 \mathrm{~m}$, având o suprafaţă de circa $7,3 \mathrm{~m}^{2}$.

Materialul descoperit în contextul locuinței este format dintr-o cantitate mare de fragmente ceramice din epoca medievală, aparţinând mai multor tipuri de vase precum: căldări (nr. cat. 18, 19, $21,22,25$ ), vase de provizii, oale (nr. cat. 29, 32, 33), străchini etc. Din materialul metalic descoperit menționăm un cuțit din fier (nr. cat. 57). De asemenea, a fost descoperit şi un număr de resturi osteologice animaliere.

Locuința $4(\mathrm{Cpl} \mathrm{7)}$ a fost identificată în suprafața $\mathrm{S} 010$. Forma este patrulateră cu colţurile rotunjite; dimensiunile generale sunt $3 \times 3 \mathrm{~m}$, având o suprafață de circa $9 \mathrm{~m}^{2}$ (PI. XIII). Complexul este săpat în sedimentul negricios ce formează nivelul de cultură (contextul 2); umplutura gropii (context 4) este de culoare brună-negricioasă cu pigmenţi de cărbune, fragmente ceramice şi fragmente de os. Orientarea complexului este $\mathrm{N}-\mathrm{S}$, iar aceasta dispune de un cuptor de interior situat în colţul de sud-est.

Cuptorul este de dimensiuni medii, având diametrul de circa $0,68 \mathrm{~m}$; în profil s-a surprins şi o parte din cupolă, înaltă de $0,32 \mathrm{~m}$. Acesta are o amenajare formată din pietre de jur-împrejurul vetrei. Vatra este simplă, formată dintr-o lutuială solidă, ce nu prezintă refaccri ulterioare. După toate aparenţele pietrele sunt spoliate din zidul perimetral al clădirii din epoca romană.

Materialul arheologic recoltat include fragmente ceramice provenite de la: oale (nr. cat. 27, 28, $30,31,32,34,35,38,39$ ), castroane (nr. cat. 15, 16), căldări (nr. cat. 20, 23), un urcior (nr. cat. 21), dar și multe fragmente atipice.

Materialul arheologic din metal este reprezentat de un vârf de săgeată din fier şi un fragment dintr-o pereche de pinteni, toate într-o stare de conservare precară.

Locuința 5 (Cpl 8) este un complex din epoca medievală, identificat în S 010. Forma gropii este de patrulater neregulat, nivelul de amenajare aflându-se în nivelul de cultură (context 2). Umplutura gropii (context 4) conţine sediment de culoare brună, afânat, în care se găsesc fragmente tegulare romane la un loc cu ceramică medicvală. Adâncimea maximă a complexului este de circa 0,42 $\mathrm{m}$, iar dimensiunile acestuia de $3,57 \times 2,85 \mathrm{~m}$, având o suprafață de $10,2 \mathrm{~m}^{2}$. Forma gropii acestei locuințe este de patrulater cu colţurile rotunjite, fără vatră de interior (PI. XIV). Orientarea locuinţei este NE-SV.

Materialul descoperit este format din fragmente ceramice aparţinând mai multor tipuri de vase medievale, precum căldări, oale (nr. cat. 43) și un capac (nr. cat. 46); alături de ceramica medievală a fost descoperit și un număr, mai puțin însemnat, de fragmente ceramice din epoca romană, dintre care amintim două ulcioare (nr. cat. 2,3) și o farfurie (nr. cat. 6). De asemenea, au fost descoperite şi fragmente osteologice animale, aparent fără urme de prelucrare. 
Locuința $6(\mathrm{Cpl}$ 9) a fost cercetată în suprafața S 035 și a fost distrusă de unul dintre şanţurile de desecare (PI. XI). Forma și dimensiunile inițiale ale locuinţei nu au putut fi stabilite, fiind identificată doar adâncimea maximă a gropii locuinţei care este de $0,44 \mathrm{~m}$. Acest complex a fost surprins în plan doar de la nivelul 3, steril arheologic, din cauza interferenţei șanţului de desecare modern. În urma cercetării, s-a stabilit că această locuinţă probabil a avut un cuptor de interior sau o vatră, deoarece s-a observat în partea inferioară a acesteia un nivel de arsură bogat în cărbuni, cenuşă și pietre.

Materialul descoperit în contextul locuinței este format dintr-o cantitate redusă de fragmente ceramice medievale și romane, căldări, oale, un fragment dintr-un bol roman (nr. cat. 7), un capac (nr. cat.48) etc., dar şi numeroase fragmente osteologice animale.

Locuința 7 (Cpl 10) este un complex din epoca medievală, identificat în S 010 (PI. X). Adâncimea maximă a gropii locuinţei este de $0,45 \mathrm{~m}$, de la nivelul unde a fost observată; forma acesteia este neregulată, iar dimensiunile generale ale complexului sunt $3,62 \times 2,79 \mathrm{~m}$, având o suprafață de circa $10,1 \mathrm{~m}^{2}$. Acest complex a fost sesizabil în plan doar de la nivelul 3 (context 6), steril arheologic. În urma cercetărilor, s-a stabilit faptul că acest complex nu avea vatră de interior, deşi în umplutura acesteia au fost identificate urme sporadice de arsură (pigmenți de cărbune).

Materialul descoperit este format din fragmente ceramice aparţinând mai multor tipuri de vase medievale, precum căldări, vase de provizii, oale, străchini. De asemenea, au mai fost descoperit şi un vârf de suliță (nr. cat. 53) și un cuțit din fier de mici dimensiuni (nr. cat. 56).

Locuința 8 (Cpl 11) a fost identificatã şi cercetată în suprafața S 035. Particularitatea acesteia este faptul că zona de nord şi est este distrusă de unul dintre şanţurile de desecare (PI. XIII). Forma locuinţei este rectangulară cu colţurile rotunjite, iar adâncimea maximă a gropii este de $0,45 \mathrm{~m}$, de la nivelul la care a fost observată. Dimensiunile generale ale complexului sunt $1,94 \times 1,81 \mathrm{~m}$. Acest complex a fost surprins în teren doar de la nivelul 3, steril arheologic, din cauza interferenţei şanțul de desecare modern. În urma cercetării s-a stabilit că această locuintă nu avea cuptor de interior, fapt observabil şi la alte complexe de dimensiuni mai mici din cadrul acestui sit.

Materialul arheologic descoperit este format dintr-o cantitate redusă de fragmente ceramice (căldări, vase de provizii, oale, străchini etc.) şi câteva fragmente osteologice animale.

Cuptorul 1 (Cpl 13) Este un cuptor, de uz gospodăresc ${ }^{38}$, separat de celelalte complexe arheologice, dar probabil în strânsă legătură cu locuințele aflate în zonă, respectiv locuința 1, locuința 2 sau locuința 8. Instalația de foc, de formă ovală, unde se afla vatra (dimensiuni $1,17 \times 0,97 \mathrm{~m}$ ), era delimitată printr-un aliniament de pietre de o groapă de deservire situată în fața gurii cuptorului. Groapa avea formă patrulateră cu colțurile rotunjite, având o suprafał̧ă de circa $2 \mathrm{~m}^{2}$ (dimensiuni 1,57 $\times 1,26 \mathrm{~m}$ ) (PI. XIV). În umplutura acesteia s-au descoperit mai multe pietre ce făceau parte din amenajarea cuptorului, precum şi materiale arheologice și zoo-arheologice.

Cuptorul 2 ( $\mathrm{Cpl} 2)$ a fost distrus în mare parte de fenomenele hidrologice amintite. Din acesta se păstrează doar vatra, cercetată în secțiunea S 009 (Pl. III). Nu au fost identificate materiale arheologice în contextul cuptorului. Este cel mai estic complex arheologic cercetat din cadrul acestui sit.

Materialul arheologic descoperit în cadrul complexelor medievale este bogat numeric, dar redus tipologic. Acesta a fost împărțit în două mari categorii, ceramică și obiecte din metal, fiecare dintre acestea cuprinzând câteva sub-categorii.

Tipologia materialului ceramic de factură medievală este foarte simplă. La Balomiru de Câmp s-au descoperit trei tipuri de vase: căldări, oale (de forme și tipuri diverse) și castroane/străchini. În catalogul selectiv prezentat la finalul excursului nostru am inclus doar o mică parte a materialului descoperit $^{39}$, în general piese uşor determinabile morfologic și tipologic.

Castroanele sunt cele mai reduse numeric dintre descoperirile de fragmente ceramice medievale de la Balomiru de Câmp. Acestea sunt bitronconice, cu buza dreaptă teșită, pastă semigrosiră, degresantul folosit fiind mica, nisipul şi oxizii de fier. Decorul este format din registre

\footnotetext{
${ }^{38}$ Mai multe despre acest tip de instalații, dar şi bibliografie, vezi la Ioniță 2009, 16, PI. 189.

${ }^{39}$ Materialul ceramic a fost în mare măsură descoperit fragmentar; piesele atipice sunt dominante ca pondere în cadrul descoperirilor.
} 
multiple de linii drepte și vălurite, incizate cu un pieptene special pe umerii și corpul vasului, uneori chiar și pe cantul buzei (nr. cat. 16).

Căldările din lut sunt prezente în toate locuințele medievale cercetate ${ }^{40}$. Vasele de acest tip au corpul tronconic sau cilindric, cu buza profilată spre interior (uneori foarte puțin și spre exterior). Pasta este semi-grosieră; degresantul este nisipul fin sau materialele organice, iar la suprafață piesele sunt lustruite ușor. Particularitatea acestui tip de vase o constituie sistemul de prindere al "toartei”, anume două perechi de perforații în cantul buzei dispuse diametral, fiecare la o distanță de circa $2 \mathrm{~cm}$ față de perechea sa. În zona perforațiilor, buza vasului este mai lată. Prin aceste perforații se petrecea o sfoară cu rol de toartă. Nu s-a descoperit nici un fragment cu decor aparent.

Oalele sunt cele mai frecvente descoperiri din cadrul locuințelor medievale. Materialul descoperit este în general fragmentar, iar tipologia s-a putut stabili doar pe baza fragmentelor din buză sau bază. Oalele au corpul zvelt, buza evazată și ușor răsfrântă, cu cantul drept sau rotunjit. Pasta este semi-grosieră, iar degresantul folosit este variat: nisip, mică, particule organice etc. Culoarea pastei variază de la gri-albăstrui la roșu-deschis, majoritatea au urme de ardere secundară. Decorul este variat, cuprinzând registre de linii orizontale sau în val, incizate, împunsāturi şi alveole, excizate în pasta crudă.

Obiectele din metal sunt reprezentate prin șase descoperiri: trei piese de armament/ echipament militar (un vârf de săgeată, un vârf de suliță și un fragment dintr-o pereche de pinteni), trei unelte casnice (un fragment de foarfece și două cuțite casnice) și cinci piroane (Pl. XX). Dintre acestea, doar armamentul este în măsură să ofere informații de natură cronologică.

Vârful de săgeată este fragmentar, descoperit în stare de conservare foarte precară. Vârful este din tipul „cu aripioară",41, înmănuşarea se face printr-o tijă terminată cu un tub cilindric (nr. cat. 54). Datarea pentru acest tip de săgeți este largă; piese de acest tip apar în zona Transilvaniei în secolul al X-lea și continuă să existe pe întreaga perioadă a Evului Mediu timpuriu (secolele X-XIII p. Chr.).

Vârful de suliță este din fier, are un corp foliform, cu tub de înmănușare și îi lipsește o parte din vârf (nr. cat. 53). Având în vedere caracteristicile morfologice și starea de conservare nu se pot emite opinii pentru încadrarea tipologică sau datarea obiectului.

Pintenii, respectiv fragmentul de pinteni (nr. cat. 55), se află într-o stare de conservare prea precară pentru a putea discuta despre tipologie sau datare ${ }^{42}$.

Piroanele și cuiele sunt piese comune pentru descoperirile arheologice din cadrul clădirilor din cpoca romană. Piesele descoperite la Balomiru de Câmp se încadrează în registrul tipic pentru provincia Dacia ${ }^{43}$.

\section{Complexe moderne/contemporane}

Situl arheologic de la Balomiru de Câmp-Pârâul Sărătii nu a fost afectat doar de lucrările agricole specifice Luncii Mureșului. Din cauza zonei mlăștinoase, pentru a desțeleni terenul în cursul ultimelor decenii s-au săpat în zonă mai multe şanțuri de desecare. Acestea neîngrijite în timp s-au ramificat, cu concursul inundațiilor ocazionale provenind de la Pârâul Sărății sau chiar de la râul Mureș. Planul acestor amenajări, dar mai ales intersecția lor cu complexele arheologice, au fost observate arheologic, atât în plan, cât și în numeroase profile (PI. VIII). Umplutura șanțurilor moderne conținea material de construcție roman, ceramică romană și medievală, dar și obiecte contemporane (plastic, sticlă etc.).

Intersectând longitudinal și transversal traseul viitoarei autostrăzi, rețeaua de şanțuri modernecontemporane a distrus zidul de nord-vest al clădirii romane, dar și locuințele medievale Cpl 11 și Cpl 9 (Pl. XI).

\footnotetext{
${ }^{40}$ În unele cazuri este vorba de fragmente foarte mānunte, motiv pentru care nu au fost ilustrate în lucrarea de față.

4 Canache, Curta 1994, 183, 217, fig I

42 Cosma 2004-2005, 177-210

${ }^{43}$ Gudea 1989, 562-569, 1008-1011, pl. CXLIX-CLII
} 
Cercetarea arheologică efectuată în perioada martie-mai 2012 pe traseul viitoarei autostrăzi Al Orăştie-Sibiu, în zona localității Balomiru de Câmp, a condus la cercetarea exhaustivă a zonei de est a sitului arheologic, fiind descoperite 11 complexe de locuire: o clădire romană, opt locuințe şi două cuptoare de exterior din epoca medievală.

Studiul materialului arheologic descoperit permite o încadrare cronologică a complexelor în două epoci istorice: romană și medievală (vezi supra). Materialul din epoca romană a fost descoperit în mare parte în afara contextului arheologic aferent clădirii romane, în special din cauza zonei mlăştinoase în care se afla situl, dar și a numeroaselor șanțuri de desecare care intersectează repetat complexul din epoca romană.

Materialul din epoca medievală a fost descoperit în contextele arheologice corespunzătoare locuințelor semi-îngropate, contribuind în mare măsură la datarea acestora. Încadrarea cronologică în intervalul secolelor XII-XIII a fost făcută în special pe baza ,căldărilor din lut" prezente din abundență în toate complexele cercetate. Limitele așezării medievale au fost determinate pe trei dintre laturi, singura necunoscută fiind latura de sud-est unde limita de expropriere a condiționat cercetarea arheologică. Dat fiind faptul că locuința 1 este poziționată foarte aproape de limita menționată putem presupune existența unor complexe similare și în afara ariei cercetate.

Recunoaşterea pe teren efectuată la nord-vest de traseul viitoarei autostrăzi, între traseul autostrăzii Al şi actualul traseu al lui DN7, a oferit indicii semnificative privind existenţa în acest areal a unei alte clădiri romane, sau a unui grup de clădiri, de dimensiuni mai mari, clădire aflată foarte probabil - în legătură cu clădirea cercetată în 2012 (Cpl 3). Aceste descoperiri vin să aducă noi date pentru cercetarea epocii romane din zona văii Mureșului, zonă cu o importanță specială privind studiul căilor de comunicației și sistemul defensiv al Daciei romane.

\section{CATALOGUL DESCOPERIRILOR ${ }^{44}$}

\section{CERAMICĂ DIN EPOCA ROMANĂ (SEC. II-III P. CHR.)}

\section{Ulcioare/amforete (Pl. XV)}

1. Amforetă/Ulcior amforoidal; $C_{p l} 4 ; 60 / 2021 ; \emptyset=$ $0,14 \mathrm{~m}, \mathrm{Hp}=0,155 \mathrm{~m}$; pastă semi-fină, brun deschis-gălbuie (10 YR, $\left.6 / 4^{45}\right)$; cu incluziuni mărunte albe, gri, şamotă, cu mica în suprafaţă şi în secţiune; fragmente din buză, gât, umăr şi toarte; Rusu-Bolindeț 2007, 426, 665, pl. CIII/630.

2. Ulcior; Cpl $8 ; 58 / 2045 ; \emptyset=0,07 \mathrm{~m}, \mathrm{Hp}=0,028$ $\mathrm{m}$; pastă fină, portocalie $(7 ; 5 \mathrm{YR}, 6 / 6)$; conține incluziuni mărunte albe şi brune, mica în suprafață și în secțiune, orificii foarte mici; fragment buză și gât; decor: caneluri pe buză și sub ea; Popilian 1976, 187, pl. XLIII/457; Rusu-Bolindeț 2007, 429, 661, pl. XCIX/604.

\footnotetext{
${ }^{44}$ Catalogul prezentat este selectiv, dar proporțional, iar numerele de ordine ale obiectelor coincid cu ilustrația. Vocile din catalog sunt prezentate după următoarele criterii şi în aceastã ordine: tip obiect; context arheologic; număr de inventar provizoriu; dimensiuni; descricre material; descriere obiect; decor obiect (după caz); bibliografie/analogii. Au fost folosite următoarele abrevieri: $\emptyset=$ diametrul fragmentului/a vasului/a capului de piron, $\mathrm{H}=$ înălțime, $\mathrm{p}=$ pāstratā, $\mathrm{L}=$ lungime, 1 = lățime, $\mathrm{Gr}=$ grosime.

${ }^{45}$ Pentru redarea culorilor s-a folosit Munsell 1994.
}

3. Ulcior; Cpl $8 ; 59 / 2048 ; \varnothing=0,08 \mathrm{~m}, \mathrm{Hp}=0,035$ $\mathrm{m}$; pastă fină, portocalie $(7 ; 5 \mathrm{YR}, 6 / 6)$; conține incluziuni mărunte albe și brune, mica în suprafață şi în secțiune, orificii foarte mici; fragment buză şi gât; decor: caneluri pe buză și sub ea; Popilian 1976, 187, pl. XLIII/457; Rusu-Bolindeț 2007, 429, 661, pl. XCIX/604.

\section{Platouri/farfurii/boluri (PI. XV)}

4. Platou; Cpl 3; 61/2053; $\varnothing=0,24 \mathrm{~m}, \mathrm{Hp}=0,035$ $\mathrm{m}$; pastă fină, brun-gălbuie deschis $(10 \mathrm{YR}, 6 / 4)$, posibil să fi avut firnis, acum exfoliat; conține incluziuni mărunte albe şi gri, mica în suprafață şi în secțiune; fragment buză şi corp; Williams 1989 , 40 , fig. 4.

5. Farfurie/bol; Cpl $5 ; 40 / 2099 ; \varnothing=0,08 \mathrm{~m}, \mathrm{Hp}=$ $0,017 \mathrm{~m}$; pastă foarte fină, portocalie $(7 ; 5 \mathrm{YR}, 6 / 6)$; conține incluziuni mărunte albe și brune, mica în suprafață și în secțiune, orificii foarte mici; Fragment picior; Prezintă urme foarte slabe de fimis roşu (2;5YR, 6/6); Popilian 1976, 216, pl. LXX/877-880.

6. Farfurie/bol; $\mathrm{Cpl} 8 ; 62 / 2045 ; \emptyset=0,20 \mathrm{~m}, \mathrm{Hp}=$ $0,04 \mathrm{~m}$; pastă semi-fină, gri $(10 \mathrm{YR}, 5 / 1)$; conține incluziuni mărunte brune şi gri, mica în suprafață şi în secțiune; fragment buză și corp; decorul este format dintr-un guler răsfrânt şi puternic profilat situat sub buză; urme de vopsea neagră la exterior; Popescu 1956, 163, fig. 104/8, 12; Gudea 1989, 490-491, pl. LXXII/6, LXXIV/7-10; Gudea 1996, 
55, 222, pl. XXXVIII/2-4, Matei, Bajusz 1997, 123, pl. LXV/l.

7. Farfurie/Bol; Cpl 9;53/2090; $\emptyset$ buză $=0,18 \mathrm{~m}$, $\varnothing$ bazã $=0,146 \mathrm{~m}, \mathrm{H}=0,049 \mathrm{~m}$; pastã semigrosieră, brună (7;5YR, 5/6); conține incluziuni mărunte şi medii albe, brune şi gri, mica în suprafață și în secțiune; fragment, profil complet; Prezintă urme de ardere secundară; Vegas 1973, 46, fig; 6, Tipo 15.

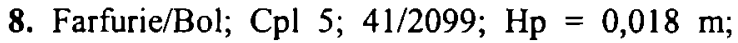
pastă fină, brun deschis-gălbuie (10YR, 6/4); conține incluziuni rare şi mărunte albe, brune şi gri, mica rară în suprafață, orificii mărunte şi rare; fragment din bază; decor: cu 3 palmete la exterior; Hayes 1972, 350, fig. 72/1; Filip 2008, 62-64, 474, pl. CLXXXVIII/D VI.1.

Oale (PI. XV)

9. Oală; Cpl 1;26/2059; $\emptyset=0,12 \mathrm{~m}, \emptyset$ bază $=$ $0,146 \mathrm{~m}, \mathrm{Hp}=0,018 \mathrm{~m}$; pastă semi-fină, gri închis (5Y, 4/1); conține incluziuni mărunte albe, brune și gri, mica în suprafaţă şi în secțiune; fragment bază inelară; fragment nedeterminabil tipologic.

10. Oală; Cpl 12;51/2045; Ø =0,12 m, Hp $=0,082$ m; pastă semi-fină, brună $(7 ; 5 \mathrm{YR}, 5 / 4)$; Conține incluziuni mărunte şi mijlocii albe, gri şi brune, mica în suprafață şi în secțiune; fragment bază; decor: 2 caneluri deasupra bazei şi mai sus, pe corp; fragment nedeterminabil tipologic;

11. Oală; $\mathrm{Cpl} 12 ; 8 / 2078 ; \emptyset=0,13 \mathrm{~m}, \mathrm{Hp}=0,061$ $\mathrm{m}$; pastă semi-fină, brună închis la interior, grialbăstrui în suprafață $(10 \mathrm{~B}, 5 / 1)$; degresantul este constituit din nisip fin; fragment buză și corp; Popilian 1976, 181, pl. XXXVI/362-364.

\section{Capace (PI. XV)}

12. Capac; Cpl 10;28/2049; $\emptyset=0,19 \mathrm{~m}, \mathrm{H}=0,059$ $\mathrm{m}$; pastă semi-grosieră, gri-albăstrui în centru, gălbui-roşcată în suprafaţă (5YR, 5/6); conține incluziuni mărunte și medii albe, brune şi gri, mica în suprafață şi în secțiune; fragment cu buton de prindere; prezintă urme de ardere secundară; Popilian 1976, 219, pl. LXXIII/932; Rusu-Bolindet 2007, 422, pl. XCVIIV/594; Rembart 2009, Taf; 24/K233.

\section{Vase de stocare (PI. XV)}

13. Chiup; $\mathrm{Cpl} 4 ; 47 / 2081 ; \emptyset=0,41 \mathrm{~m}, \mathrm{Hp}=0,097$ $\mathrm{m}$; pastă grosieră, gri la mijloc, gri deschis în suprafață $(4 / N)$; conține incluziuni mărunte, mijlocii şi mari albe, gri, galbene și brune, mica în suprafață şi în secțiune; Fragment buză şi corp; decor: o canelură pe umăr; Popilian 1976, 114-116, chiup tipul 1, nr; 746, pl. LXI); Rusu-Bolindet 2007, 426-427, pl. CIV/636.

\section{Varia (Pl. XV)}

14. Opaiț; Cpl 3; 29/2089; Ø bază $=0,04 \mathrm{~m}, \mathrm{Hp}=$ $0,028 \mathrm{~m}$; pastă fină portocalie $(7 ; 5 Y R, 6 / 6)$, fără incluziuni, cu mica în suprafaţă şi în secţiune; fragment din rezervorul circular, cu ştampila
FAVO(R) F, aplicată pe baza plată; ștampila are 2 registre: pe primul rând se poate citi FAVO, existând o ligatură între literele $\mathrm{A}$ şi $\mathrm{V}$, iar ultima literă, $\mathrm{R}$, este destul de ştearsă; pe al doilea registru avem litera $\mathrm{F}$ care este prescurtarea cuvântului FECIT; nu poate fi determinat din punct de vedere tipologic; urme de ardere secundară pe partea dorsală; Leoschcke 1919, 296; Alicu 1994, 20.

\section{CERAMICÃ MEDIEVALÃ (SEC. XI-XIII P. CHR.) ${ }^{46}$}

\section{Castroane/străchini (PI. XVII)}

15. Castron; Cpl 7; 31/2035; Ø $=0,16 \mathrm{~m}, \mathrm{Hp}=0,03$ $\mathrm{m}$; pastă semi-grosieră, brună-gălbuie; conține incluziuni mărunte albe, brune şi gri $(7 ; 5 \mathrm{YR}, 4 / 6)$; mica în suprafață și în secțiune; fragment buză; decor: un decor de linie în val incizatã, dedesubt un registru de linii orizontale, paralele, incizate; prezintă urme de ardere secundară;

16. Castron; Cpl 7; 15/2040; $\emptyset=0,14 \mathrm{~m}, \mathrm{Hp}=$ $0,041 \mathrm{~m}$; pastă semi-grosieră, brună-gălbuie (7;5YR, 4/6); conține incluziuni mărunte albe, brune şi gri, mica în suprafață și în secțiune; fragment buză; decor: un decor de linie in val incizată, dedesubt două registre de linii orizontale, paralele, incizate; prezintă urme de ardere secundară;

17. Vas; Cpl $1 ; 57 / 2036 ; \emptyset=$ indeterminabil, $\mathrm{Gr}=$ $0,006 \mathrm{~m}$; pastă semi-grosieră, brună la interior, grialbăstruie spre exterior $(7 ; 5 \mathrm{YR}, 5 / 4)$; conține incluziuni mãrunte albe și gri, mica în suprafață și în sectiune; fragment bază; decor: la exterior are un „X" marcat în relief, ce reprezintã o marcã de olar; urme de ardere secundară la exterior; Cosma 1992, 232-235, pl. IX/7; Tiplic et alii 2004, 201, fig. 3/l, r; Ioniţă 2009, pl. 267/1a.

\section{Căldări (PI. XVI)}

18. Căldare; Cpl 6; 34/2084; $\emptyset=0,30 \mathrm{~m}, \mathrm{Hp}=$ $0,043 \mathrm{~m}$; pastă semi-gтosieră, brună foarte închis la mijloc, brună în suprafață $(7 ; 5 Y R, 4 / 6)$; conține incluziuni mărunte albe, brune şi gri, mica în suprafață şi în secțiune; fragment buză cu 2 urechiușe de prindere perforate, orientate spre interiorul vasului; urme de ardere secundară; Diaconu 1958, 425, fig. 4/1; Cosma 1992, 232-235, pl. XIIl/2; Tiplic et alii 2004, 205, fig. 7/m, g; Ioniţă 2009, pl. 273/D3.

19. Căldare; Cpl 6; 33/2084; $\emptyset=0,30 \mathrm{~m}, \mathrm{Hp}=$ $0,035 \mathrm{~m}$; pastă semi-grosieră, brună în suprafață (7;5YR, 5/6); conține incluziuni mărunte albe, brune și gri, mica în suprafață și în secțiune; Fragment buză cu 2 urechiușe de prindere perforate, orientate spre interiorul vasului; urme de ardere secundară; Cosma 1992, 232-235, pl. XIII/2; Tiplic et alii 2004, 205, fig. 7/m, g; Ioniţă 2009, pl. 273/D3.

${ }^{46}$ Autorii doresc să mulțumească dr. Mihai Gabriel Vasile (MNIR) pentru ajutorul acordat în datarea lotului de material ceramic din epoca medievală. 
20. Căldare; Cpl 7; 20/2035; Ø int; $=0,28 \mathrm{~m}, \mathrm{Hp}=$ $0,072 \mathrm{~m}$; pastă semi-grosieră, gri în centru, brună în suprafață (7;5YR, 5/6); Conține incluziuni mărunte şi medii albe, brune şi gri, mica în suprafață şi în secțiune; fragment buză şi corp; urme de ardere secundară la exterior; Tiplic et alii 2004, 205, fig. 7/m, g; Ioniţă 2009, pl. 273/BIV5.

21. Căldare; $\mathrm{Cpl} 6 ; 35 / 2084 ; \emptyset=0,26 \mathrm{~m}, \mathrm{Hp}=$ $0,042 \mathrm{~m}$; pastă semi-grosieră, gri la mijloc, brună în suprafață exterior fragment (ardere secundară), bej închis în suprafață interior fragment (10YR, 5/1); conține incluziuni mărunte albe şi gri, mica în suprafață şi în secțiune; fragment buză cu o urechiuşă de prindere perforată, orientată spre interiorul vasului; Diaconu 1958, 425, fig. 4/1; Cosma 1992, 232-235, pl. XIII/2; Tiplic et alii 2004, 205, fig. 7/m, g; Ioniţă 2009, pl. 273/D1.

22. Căldare; Cpl 6; 36/2084; $\emptyset=0,30 \mathrm{~m}, \mathrm{Hp}=$ $0,054 \mathrm{~m}$; pastă semi-grosieră, brună deschis la mijloc, brună în suprafață $(7 ; 5 \mathrm{YR}, 4 / 6)$; conţine incluziuni mărunte albe, brune și gri, mica în suprafață și în secțiune; fragment buză cu 2 urechiușe de prindere perforate, orientate spre interiorul vasului; urme de ardere secundară; Diaconu 1958, 425, fig. 4/1; Cosma 1992, 232-235, pl. XIII/2; Ioniţă 2009, pl. 273/D3;

23. Căldare; $\mathrm{Cpl} \mathrm{7;} \mathrm{19/2035;} \oslash=0,20 \mathrm{~m}, \mathrm{Hp}=$ $0,058 \mathrm{~m}$; pastă semi-grosieră, neagră în centru, brună-gălbuie în suprafață (10YR, 5/4); conține incluziuni mărunte albe, brune şi gri, mica în suprafață și în secțiune; fragment buză cu o urechiușă de prindere perforată, orientată spre interiorul vasului; urme de ardere secundară la exterior; Cosma 1992, 232-235, pl. XIV/1; Ioniţă 2009, pl. 264, 24;

24. Căldare; $\mathrm{Cpl} 4 ; 23 / 2047 ; \emptyset=0,30 \mathrm{~m}, \mathrm{Hp}=0,04$ $\mathrm{m}$; pastă semi-grosieră, gri închis la interior, bej în suprafață $(7 ; 5 \mathrm{YR}, 4 / 1)$; conține incluziuni mărunte albe, brune şi gri, mica în suprafață și în secțiune; fragment buză cu 2 urechiuşe de prindere perforate (între care una fragmentară), orientate spre interiorul vasului; Diaconu 1958, 425, fig. 4/1; Ioniţă 2009, pl. 274/A-A';

25. Căldare; Cpl 6; 32/2084; Ø =0,34 m, Hp $=0,08$ $\mathrm{m}$; pastã semi-grosieră, gri închis albăstrui la interior, bej închis în suprafață $(5 \mathrm{~PB}, 3 / 1)$; conține incluziuni mărunte albe şi gri, mica în suprafață şi în secțiune; fragment buză cu 2 urechiuşe de prindere perforate, orientate spre interiorul vasului; Diaconu 1958, 425, fig. 4/1; Cosma 1992, 232-235, pl. XIII/2; Tiplic et alii 2004, 205, fig. 7/m, g; Ioniţă 2009, pl. 273/BII4.

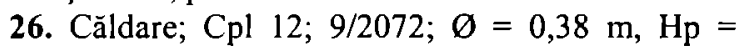
$0,096 \mathrm{~m}$; pastă semi-grosieră, gri închis-albăstruie $(5 \mathrm{~PB}, 4 / 1)$; conține incluziuni mărunte şi mijlocii albe şi gri, mica în suprafaţă şi în secțiune; fragment buză; Diaconu 1958, 425, fig. 4/1; Ioniţă 2009, pl. 273/Bl2;

\section{Oale (PI. XVII-PI. XVIII)}

27. Oală; Cpl 7;16/2040; Ø $=0,16 \mathrm{~m}, \mathrm{Hp}=0,061$ $\mathrm{m}$; pastă semi-grosieră, gri închis la mijloc, brună închis în suprafață $(7 ; 5 Y R, 5 / 6)$; conține incluziuni mărunte albe, brune şi gri, mica în suprafață şi în secțiune; fragment buză cu canelură pentru capac; Decor: un registru de 6 linii paralele, orizontale, incizate; urme de ardere secundară; Țiplic et alii 2004, 203, fig. 5/d; Ioniţă 2009, pl. 246/69.

28. Oală; Cpl 7;11/2035; $\emptyset=0,135 \mathrm{~m}, \mathrm{Hp}=0,05$ $\mathrm{m}$; pastă semi-grosieră, gri la mijloc, roșcat-gălbuie în suprafață $(7 ; 5 \mathrm{YR}, 6 / 6)$; Conține incluziuni mărunte albe, brune şi gri, mica în suprafață şi în secțiune; Fragment buză cu canelură pentru capac; decor: un registru de linii în val pe umărul vasului; urme de ardere secundară; Berciu 1957, 352, pl. III, 14; Tiplic et alii 2004, 201, fig. 3/n; Ioniță 2009, pl. 273/III 2.

29. Oală; Cpl 6; 37/2089; Ø=0,20 m, Hp=0,07 m; pastă semi-grosieră, neagră la mijloc, brună în suprafață $(7 ; 5 Y R, 5 / 4)$; conține incluziuni mărunte şi mijlocii albe, brune şi gri, mica în suprafață şi în secțiune; fragment buză și corp; decor: 3 caneluri paralele; urme de ardere secundară; Tiplic et alii 2004, 201, fig. 3/n; Ioniţă 2009, pl. 257, II/1984, 1.

30. Oală; Cpl 7;14/2040; $\emptyset=0,20 \mathrm{~m}, \mathrm{Hp}=0,088$ $\mathrm{m}$; pastă semi-grosieră, gri închis la mijloc, brună în suprafață $(7 ; 5 \mathrm{YR}, 5 / 6)$; conține incluziuni mărunte albe, brune și gri, mica în suprafață și în secțiune; prezintă urme de ardere secundară; fragment buză şi corp; decor: un registru de alveole și 2 registre de linii paralele incizate; Berciu 1957, pl. II, 7, 352; Cosma 1992, 232-235, pl. X/12; Ionită 2009, pl. 245, 55, pl. 257/ II/1984, 1; Țiplic et alii 2004, 202, fig. $4 / \mathrm{c}$.

31. Oală; Cpl 7; 42/2040; Ø $=0,18 \mathrm{~m}, \mathrm{Hp}=0,078$ $\mathrm{m}$; pastã semi-grosierã, neagrã la mijloc, roșcatgălbuie în suprafạ̦ă $(7 ; 5 \mathrm{YR}, 6 / 6)$; conține incluziuni mărunte albe, brune și gri, mica în suprafață și în secțiune; fragment buză cu canelură pentru capac; decor: registru de alveole oblice; urme de ardere secundară; Ioniţă 2009, pl. 243/32; Tiplic et alii 2004, 205, fig. 7/l.

32. Oală; $\mathrm{Cpl} 7 ; 2 / 2021 ; \emptyset=0,18 \mathrm{~m}, \mathrm{Hp}=0,068 \mathrm{~m}$; pastă semi-grosieră, gri la mijloc, brună în suprafață (7;5YR, 4/6); conține incluziuni mărunte albe și gri, mica în suprafață și în secțiune; Fragment buză cu canelură pentru capac; decor: 3 registre de linii orizontale, paralele, incizate; urme de ardere secundară; Țiplic et alii 2004, 205, fig. 7/c; Ioniţă 2009, pl. 272/V 6.

33. Oală; $\mathrm{Cpl} 6 ; 38 / 2089 ; \emptyset=0,18 \mathrm{~m}, \mathrm{Hp}=0,079$ $\mathrm{m}$; Pastă semi-grosieră, gri la mijloc, brună-gãlbuie în suprafață $(7 ; 5 \mathrm{YR}, 5 / 6)$; conține incluziuni mărunte albe şi gri, mica în suprafață și în secțiune; fragment buză şi corp; Prezintă urme de ardere secundară; decor: 3 registre de decor liniar în val, intercalată o canelură; Țiplic et alii 2004, 201, fig. 3/o, l; Ioniţă 2009, pl. 255/20. 
34. Oală; $\mathrm{Cpl} 7 ; 18 / 2035 ; \emptyset=0,12 \mathrm{~m}, \mathrm{Hp}=0,059$ $\mathrm{m}$; pastă semi-grosieră, brună $(7 ; 5 \mathrm{YR}, 5 / 6)$; conține incluziuni mărunte albe şi gri, mica în suprafață și în secțiune; Fragment buză și corp; decor: 3 linii orizontale, paralele, incizate pe buză la exterior, un registru de linii paralele, orizontale, incizate pe umăr; urme de ardere secundară; Țiplic et alii 2004, 201, fig. $3 / \mathrm{n}$.

35. Oală; Cpl 7; 43/2035; Ø =0,12 m, Hp =0,03 m; pastă semi-grosieră, brună-gălbuie $(10 \mathrm{YR}, 5 / 4)$; conține incluziuni mărunte albe, brune şi gri, mica în suprafață și în secțiune; Fragment buză și corp; decor: rețea de linii oblice fãcute cu rotița pe umăr; urme puternice de ardere secundară; Țiplic et alii 2004, 201, fig. 3/n; Ioniţă 2009, pl. 272/II 8, pl. $271 / \mathrm{p}$.

36. Oală; Cpl 1; 64/2094; Ø =0,18 m, Hp =0,049 m; pastă semi-grosieră, roşuiegălbuie (5YR, 4/6); conține incluziuni mărunte şi medii albe şi gri, mica în suprafață şi în secțiune; fragment buză și corp; decor: un registru de 3 linii paralele pe umăr Tiplic et alii 2004, 201, fig. 3/n; loniţă 2009, pl. 272/1II 2;. 37. Oală; Cpl 5; 27/2063; Ø =0,16 m, Hp =0,07 m; pastă semi-grosieră, gri în centru, brun intens în suprafał̦ă $(7 ; 5 \mathrm{YR}, 5 / 6)$; conține incluziuni mărunte și mijlocii albe, brune și gri, mica în suprafață și în secțiune; fragment buză cu canelură pentru capac și corp; decor: o nervură pe umăr; urme de ardere secundară la exterior; Tiplic et alii 2004, 201, fig. 3/l; Ionită 2009, pl. 260/ 20.

38. Oală; $\mathrm{Cpl} 7 ; 1 / 2021 ; \emptyset=0,16 \mathrm{~m}, \mathrm{Hp}=0,056 \mathrm{~m}$; pastă semi-grosieră, gri în centru, roşiatică-gălbuie în suprafałă $(5 Y R, 4 / 6)$; conține incluziuni mărunte şi mijlocii albe, brune şi gri, mica în suprafață şi în secțiune; fragment buză şi corp; decor: un registru de 8 linii orizontale paralele pe umăr; urme de ardere secundară la exterior; Tịplic et alii 2004, 201-202, fig. 3/o, fig. 4/c; loniţă 2009, pl. 272/1 4.

39. Oală; $\mathrm{Cpl} 7 ; 12 / 2035 ; \varnothing=0,13 \mathrm{~m}, \mathrm{Hp}=0,037$ $\mathrm{m}$; pastă semi-grosieră, gri închis în centru, roşcatăgălbuie în suprafață $(7 ; 5 \mathrm{YR}, 6 / 6)$; conține incluziuni mărunte brune şi gri, mica în suprafață și în secțiune; fragment buză cu canelură pentru capac şi corp; decor: un registru de linii orizontale paralele exteriorul buzei, 2 registre de decor în valuri, iar dedesubt un inceput de decor cu linii orizontale paralele pe umăr; urme de ardere secundară la exterior; Tiplic et alii 2004, 203, fig. 5/f; Ionif̧ă 2009, pl. 272/VI 6.

40. Oală; $\mathrm{Cpl} \mathrm{7;3/2021;} \mathrm{Ø}=0,12 \mathrm{~m}, \mathrm{Hp}=0,05 \mathrm{~m}$; pastă semi-grosieră, gri în centru, roşiatică-gălbuie în suprafatăă (5YR, 5/6); conține incluziuni mărunte brune şi gri, mica î suprafață și în secțiune; Fragment buză cu canelură pentru capac şi corp; decor: decor in valuri şi 2 registre de linii orizontale paralele pe umăr; urme de ardere secundară la exterior; Cosma 1992, 232-235, pl. IX/9; Ioniţă 2009, pl. 272/II 7, pl. 271/ h;

41. Oală; Cpl $1 ; 25 / 2019$; $\emptyset$ int; $=0,24 \mathrm{~m}, \mathrm{Hp}=$ $0,047 \mathrm{~m}$; pastă semi-grosieră, gri foarte închis în centru, gri deschis-măsliniu în suprafaţă $(5 \mathrm{Y}, 6 / 2)$; conține incluziuni dese mărunte şi mijlocii, albe, brune şi gri, mica în suprafață şi în secțiune; fragment buză şi corp; decor: un registru de 4 linii orizontale paralele pe umăr; urme de ardere secundară la exterior; Tiplic et alii 2004, 203, fig. 5/b; Ioniţă 2009, pl. 272/1 4.

42. Oală; Cpl 1;24/2019; Ø $=0,16 \mathrm{~m}, \mathrm{Hp}=0,041$ $\mathrm{m}$; pastă semi-grosieră, brună foarte închis cu nuanțe gri în centru, nagră-albăstruie în suprafată (5PB $2 ; 5 / 1)$; conţine incluziuni mărunte şi mijlocii, albe și gri, mica în suprafață şi în secțiune; fragment buză și corp; decor: un registru de 4 linii orizontale paralele pe umăr; Țiplic et alii 2004,202 , fig. 4/b; Ioniţă 2009, pl. 272, III 5.

43. Oală; Cpl 8; 4/2045; Ø =0,17 m, Hp=0,077 m; pastă semi-grosieră, gri-albăstruie în centru, brună deschis-oliv în suprafață $(2 ; 5 \mathrm{Y}, 5 / 3)$; conține incluziuni mărunte şi mijlocii, albe şi gri, mica în suprafață şi în secţiune; fragment buză şi corp; decor: 4 caneluri pe corp; Tiplic et alii 2004, 201, fig. 3/a; loniţă 2009, pl. 272/III 4.

44. Oală; Cpl 9;52/2090; Ø =0,13 m, Hp=0,09 m; pastă grosieră, roşie închis $(2 ; 5 \mathrm{YR}, 3 / 3)$; conține incluziuni mărunte albe şi gri, mica în suprafață şi în secțiune; fragment bază plată; urme de ardere secundară la exterior; Tiplic et alii 2004, 201, fig. 3/r; Ioniţă 2009, pl. 251/140; Marcu-Istrate 2007, 262, pl. 38/5.

45. Oală; $\mathrm{Cpl} \mathrm{12;10/2072;} \mathrm{Ø} \mathrm{=0,11} \mathrm{m,} \mathrm{Hp}=0,052$ $\mathrm{m}$; pastă semi-grosieră, gri $(2 ; 5 \mathrm{YR}, 5 / 1)$; conține incluziuni mărunte şi medii albe, brune şi gri, mica în suprafață și în secțiune; fragment bază și corp; urme de ardere secundară; Tiplic et alii 2004, 201, fig. 3/r; Ioniţă 2009, pl. 256, 28.

\section{Capace (PI. XVIII)}

46. Capac; Cpl 8; 65/2045; Ø buton $=0,042 \mathrm{~m}$, $\mathrm{Hp}=0,04 \mathrm{~m}$; pastă grosieră, gri-albăstrui $(10 \mathrm{~B}$, 5/1); conține incluziuni mărunte şi medii albe, brune şi gri, mica în suprafață și în secțiune; fragment capac cu buton de prindere; Popa 2011, 426, pl. 172/3.

47. Capac; Cpl 5; 39/2099; Ø buton $=0,058 \mathrm{~m}, \mathrm{H}=$ $0,058 \mathrm{~m}$; pastă grosieră, gri-verzui în centru, brun deschis-gălbui în suprafață (10YR, 4/4); conține incluziuni mărunte şi medii albe, brune şi gri, mica în suprafață şi în secțiune; fragment capac cu buton de prindere; urme de ardere secundară; Popa 2011, 508, pl. 187/13.

48. Capac; Cpl 9; 17/2095; Ø buton $=0,046 \mathrm{~m}, \mathrm{H}=$ $0,05 \mathrm{~m}$; pastă grosieră, gri-oliv în centru, brună în suprafată $(7 ; 5 Y R, 4 / 4)$; conține incluziuni mărunte şi medii albe, brune şi gri, mica în suprafață și în secțiune; fragment capac cu buton de prindere; in mijlocul butonului de prindere are un orificiu aproximativ circular, adânc de cca; $0,01 \mathrm{~m}$; urme de ardere secundară; Popa 2011, 508, pl. 187/4, 13. 
III. MATERIAL TEGUlaR (SEC. II-III P. CHR.) (PI. XIX)

49. Tegulă; $C p l 3 ; 30 / 2051 ; L=0,123 \mathrm{~m}, \mathrm{l}=0,115$ $\mathrm{m}, \mathrm{gr} ;=0,03 \mathrm{~m} ;$ pastă grosieră, roșie-închis (2;5YR, 4/8), cu incluziuni mărunte şi mijlocii, albe, brune, gri, mica în secțiune și în suprafață; fragment țiglă cu urmele a două litere (LS) executate în pasta crudă; litera L se păstrează fragmentar; IDR III/3, 202, Ia-Ic; Floca et alii 1974, 111; Branga 1980, 145-146, fig. 85-86.

50. Tegulă; Cpl 3;22/2054; L =0,18 m, l = 0, 092 m, gr; = 0,025 m; pastă grosieră, roşiatică $(2 ; 5 \mathrm{YR}$, 4/3), cu incluziuni mărunte şi mijlocii, albe, brune, gri, mica rară în secțiune şi în suprafață; fragment țiglă cu urmele a două litere (LS) executate în pasta crudă; Litera $L$ se păstrează fragmentar; urme de ardere secundară în suprafatăa; IDR III/3, 202, Ia-Ic; Floca et alii 1974, 111; Branga 1980, 145-146, fig. 85-86.

51. Tegulă; $\mathrm{Cpl} 3 ; 45 / 2053 ; \mathrm{L}=0,065 \mathrm{~m}, \mathrm{l}=0,53$ $\mathrm{m}, \mathrm{gr} ;=0,024 \mathrm{~m}$; pastă grosieră, roșcată-gălbuie (5YR, 4/6), incluziuni mărunte şi mijlocii, albe, brune, gri, mica în secțiune și în suprafață; fragmentară; are o urmă fragmentară de 2 degete; Wikander 1993, fig. 44-45, p; 114;

52. Tegulă; Cpl 3; 44/2052; L = 0,106 m, $1=0,071$ $\mathrm{m}, \mathrm{gr} ;=0,028 \mathrm{~m}$; pastă grosieră, roșu închis (2,5YR, 4/8), incluziuni mărunte și mijlocii, albe, brune, gri, mica în secțiune și în suprafață; fragmentară; are o urmă fragmentară de talpă picior stâng (primele 3 degete și o mică porțiune din suprafața plantară); Wikander 1993, 114, fig. 4445 ;

\section{PIESE DIN METAL}

\section{Echipament militar (PI. XX)}

53. Vârf de suliță; $\mathrm{Cpl} 10 ; 66 / 2042 ; \mathrm{Lp}=0,128 \mathrm{~m} ; 1$ $=0,029 \mathrm{~m} ; \emptyset=1,28 \mathrm{~m}$; piesă din fier, corp foliform, cu tub de înmănușare, lipsește o parte din vârf.

54. Vârf de săgeată; $\mathrm{Cpl} 7 ; 68 / 2024 ; \mathrm{L}=0,088 \mathrm{~m}$; $\operatorname{lmax}=0,028 \mathrm{~m} ; \emptyset=0,012 \mathrm{~m}$; piesă din fier, corp triunghiular cu colţurile înspicate; înmănuşarea se face printr-o tijă terminată cu un mic tub cilindric; starea de conservare este precară, piesa se păstrează fragmentar, lipsindu-i un colț din vârf şi o parte din tubul de înmănuşare; Canache, Curta 1994, 183, 217 , fig 1 .

55. Pinten din fier; $\mathrm{Cpl} 7 ; 67 / 2039 ; \mathrm{L}=0,098 \mathrm{~m} ; \mathrm{H}$ $=0,03 \mathrm{~m}$; are un ghimpe biconic prins de un corp semi-circular; piesa se păstrează fragmentar, lipsindu-i un braț de prindere; Cosma 2004-2005, 177-210.

\section{Unelte (PI. XX)}

56. Cuțit din fier; Cpl 10;69/2043; L $=0,105 \mathrm{~m}$; Lamă $=0,089 \mathrm{~m} ; \mathrm{l}=0,015 \mathrm{~m}$; de mici dimensiuni, cu lama foliformă ascuțită pe o singură parte; se păstrează lama întreagă şi o parte din pedunculul de prindere în plăsele.

57. Cuțit din fier; $\mathrm{Cpl} 6 ; 71 / 2086 ; \mathrm{L}=0,017 \mathrm{~m}$; Lamă $=0,195 \mathrm{~m} ; 1=0,018 \mathrm{~m}$; lama dreptunghiulară cu vârful triunghiular, tăişul pe o singură parte; Starea de conservare este precară, lama este ciobită în multe locuri.

58. Foarfece; Cpl 7; 70/2030; L =0,210 m; Lamă $=$ $0,121 \mathrm{~m} ; 1=0,019 \mathrm{~m}$; piesă din fier, cu lama triunghiulară alungită, mânerul format dintr-o tijă în formă de „,"; din foarfece se păstrează doar jumătate, în locul de îmbinare având un nit; Țânțăreanu 2010, 345, pl. LXXXV/1.

\section{Piroane şi cuie (PI. XX)}

59. Piron; $\mathrm{Cpl} 3 ; 72 / 2086 ; \mathrm{L}=0,140 \mathrm{~m} ; \varnothing$ cap $=$ $0,035 \mathrm{~m}$; piesă din fier, corpul este pătrat în secțiune; Gudea 1989, 562-569, 1008-1011, pl. CXLIX-CLII.

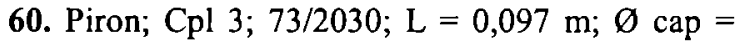
$0,020 \mathrm{~m}$; piesă din fier, corpul este pătrat în secțiune; Gudea 1989, 562-569, 1008-1011, pl. CXLIX-CLII.

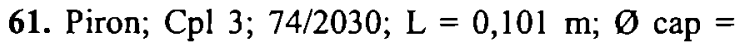
$0,027 \mathrm{~m}$; piesã din fier, corpul este pătrat în secțiune; Gudea 1989, 562-569, 1008-1011, pl. CXLIX-CLII.

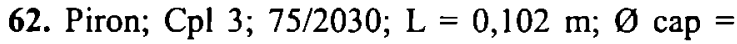
$0,025 \mathrm{~m}$; piesă din fier, corpul este pătrat în secțiune; Gudea 1989, 562-569, 1008-1011, pl. CXLIX-CLII.

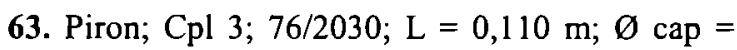
$0,018 \mathrm{~m}$; piesă din fier, corpul este pătrat în secțiune; Gudea 1989, 562-569, 1008-1011, pl. CXLIX-CLII. 


\section{BIBLIOGRAFIE}

Alicu 1994

Bâltâc 2011

Berciu 1957

Branga 1980

Branga 1986

Canache, Curta 1994

Cosma 1992

Cosma 1996

Cosma 2004-2005

Diaconu 1956

Floca 1953

Floca et alii 1974

Fodorean 2003

Gudea 1989

Gudea 1996

Hayes 1972

Ioniţă 2009

Loeschcke 1919

Lukacs 1984

Marcu-Istrate 2007

Matei, Bajusz 1997

Mihãilescu 1969

Mitrofan 1973

Moga, Ciugudean 1995

Munsell 1994

Orghidan 1969

Petolescu 2010

Popa 2011

Popescu 1956

Popilian 1976

Rembart 2009

Rusu-Bolindeț 2007
D. Alicu, Opaifele romane de la Ulpia Traiana Sarmisegetusa, București, 1994

A. Bâltâc, Lumea rurală in provincille Moesia și Thracia (secolele I-III p. Chr.), București, 2011

I. Berciu, Descoperiri din epoca feudală timpurie din raionul Alba Iulia, $M C A, I V$, 1957, p. 335-360

N. Branga, Urbanismul Daciei romane, Timișoara, 1980

N. Branga, Italicii si veteranii din Dacia. Mărturii epigrafice şi arheologice, Timișoara, 1986

A. Canache, F. Curta, Depozite de unelte şi arme medievale timpurii de pe teritoriul României, Mousaios, IV/1, 1994, p. 179-221

C. Cosma, Ceramica prefeudală şi feudală timpurie de la Orșova, Eph.Nap., II, 1992, p. 231-235

C. Cosma, Considerații privind aşezările rurale și tuipurile de locuințe din Transilvania în secolele VIII-X, Eph.Nap., VI, 1996, p. 261-280

C. Cosma, Pinteni medievali timpurii descoperiți pe teritoriul Transilvaniei (secolele VIII-X), Eph.Nap., XIV-XV, 2004-2005, p. 177-210

$\mathrm{P}$. Diaconu, $\mathrm{Cu}$ privire la problema căldărilor de lut în epoca feudală timpurie, $S C I V, 7,1956,3-4$, p. $421-439$

O. Floca, Ferma (villa rustica) din epoca sclavagistă romană, $M C A, \mathrm{I}, 1953$, p. 752-753

O. Floca, M. Mărghitan, St. Ferenczi, Grupul de cuptoare pentru ars ceramica de la Micia, Deva, 1974

F. Fodorean, Evoluția cercetărilor privind drumurile romane din Dacia, Revista Bistritei, XVII, 2003, p. 55-68

N. Gudea, Porolissum. Un complex arheologic daco-roman la marginea de nord a Imperiului roman. Vol. I (Cercetări și descoperiri arheologice până în anul 1977) (= ActaMP, XIII), Zalău, 1989

N. Gudea, Porolissum. Un complex arheologic daco-roman la marginea de nord a Imperiului roman. II. Vama romană. Monografie arheologică. Contributii la cunoaşterea sistemului vamal din provinciile dacice, Bibliotheca Musei Napocensis XII, Cluj-Napoca, 1996

J. W. Hayes, Late Roman Pottery. The British School at Rome, London, 1972

A. Ioniţa, Aşezarea din secolele XII-XIII de la Bratei, Alba Iulia, 2009

S. Loeschcke, Lampen aus Vindonissa, Zurich, 1919

A. Lukacs, Observaţii privind răspîndirea căldărilor de lut pe teritoriul României, SCIVA, 35, 1984, 4, p. 320-330

D. Marcu-Istrate, Sibiu. Piaţa Huet. Monografie arheologică, Sibiu, 2007

Al. V. Matei, I. Bajusz, Castrul roman de la Romita-Certiae/Das Römergrenzkastell von Romita-Certiae. Führer zu archäologischen Denkmälern, in Dacia Porolissensis Nr. 4/Ghid al monumentelor arheologice din Dacia Porolissensis nr. 4, Zalău, 1997

V. Mihăilescu, Geografia fizică a României, Bucureşti, 1969

N. Mitrofan, Villae rusticae în Dacia Superior I, ActaMN, X, 1973, p. 127-150

Repertoriul arheologic al judetului Alba, ed. V. Moga, H. Ciugudean, Alba Iulia, 1995

Munsell Soil Color Chart, New Windsor, 1994

N. Orghidan, Vãile transversale din România. Studiu geomorfologic, București, 1969

C. C. Petolescu, Dacia. Un mileniu de istorie, București, 2010

C. I. Popa, Valea Cugirului din preistorie până în zorii epocii moderne, ClujNapoca, 2011

D. Popescu, Cercetări arheologice în Transilvania, $M C A$, II, 1956, p. 175-180

Gh. Popilian, Ceramica romană din Oltenia, Craiova, 1976

L. Rembart, Die Datierung des sogenannten Serapeion in Ephesos anhand des stratifizierten Fundmaterials, Wien, 2009

V. Rusu-Bolindeț, Ceramica romană de la Napoca, Cluj-Napoca, 2007 
Țânțăreanu 2010

Țiplic et alii 2004

Vegas 1973

Wikander 1993

Williams 1989

IDR III/3
E. Țânțăreanu, Habitat medieval în sud-vestul Munteniei in sec. XIV-XVII. Temeiuri istorice şi arheologice, Alexandria, 2010

I. M. Țiplic, S. Cociș, V. Voișian, Descoperii medievale timpurii la Cluj-Napoca str. V. Deleu, Revista Bistriţei, XVIII, 2004, p. 195-208

M. Vegas, Cerámica común romana del mediteráneo occidental, Barcelona, 1973

Ö. Wikander, Acquarossa. Vol. VI. The Roof Tiles, part 2: Typology and techical features, Stockholm, 1993

C. Williams, Anemurium. The Roman and Early Byzantine Pottery, Toronto, 1989 Inscripłiile Daciei Romane, vol. III/3, D. M. Pippidi, Ion I. Rusu (ed.), Bucureşti, 1984

\section{LIST OF ILLUSTRATIONS}

PI. I. General position of Balomiru de Câmp archaeological site on the map of Romania: 1. General view (Google Maps); 2. Distribution of finds in the Şibot area (open source caption from Google Earth)

Pl. II. General plan of Balomiru de Câmp archaeological site overlapped on a satellite photograph (Google Earth)

PI. III. Balomiru de Câmp-Pârâul Sărății. General plan of the research.

PI. IV. 1. Trenches S 010 and S 015 - panoramic view; 2-3. Overview of the site

PI. V. The roman age building: 1 . North side view; 2 . West side view

PI. VI. 1. Complex no. 8 - kiln cross-section; 2. Complex no. 6-kiln cross-section; 3. Complex no. 7 - crosssection

PL. VII. 1. Complex no. 13 - cross-section; 2. Complex no. 16 - plan; 3. Complex no. 1 -cross-section

PI. VIII. Main cross-section of the Section S 009 - north-east

Pl. IX. Plan of the roman building

PL. X. 1. Complex no. 1 - plan and cross-section; 2. Complex no. 10 - plan and cross-section

PI. XI. 1. Complex no. - cross-section; 2. Complex no. 4 - cross-section; 3. Complex no. 12 -cross-section

PI. XII. Complex no. 6 - plan and cross-section

PI. XIII. 1. Complex no. 7 - plan and cross-section; 2. Complex no. 11 - plan and cross-section

PI. XIV. 1. Complex no. 13 - plan and cross-section; 2. Complex no. 8-plan and cross-section

PI. XV. Roman pottery

PI. XVI. Medieval pottery. Clay cauldrons

PI. XVII. Medieval pottery: 15-16. Bowls; 17-36. Pots

PI. XVIII. Medieval pottery: 37-45. Pots; 46-48. Pot-covers

PI. XIX. Roman tiles finds

Pl. XX. Iron finds: 53. Spear-head; 54. Arrow-head; 55. Spur; 56-57. Knives; 59-63. Nails 



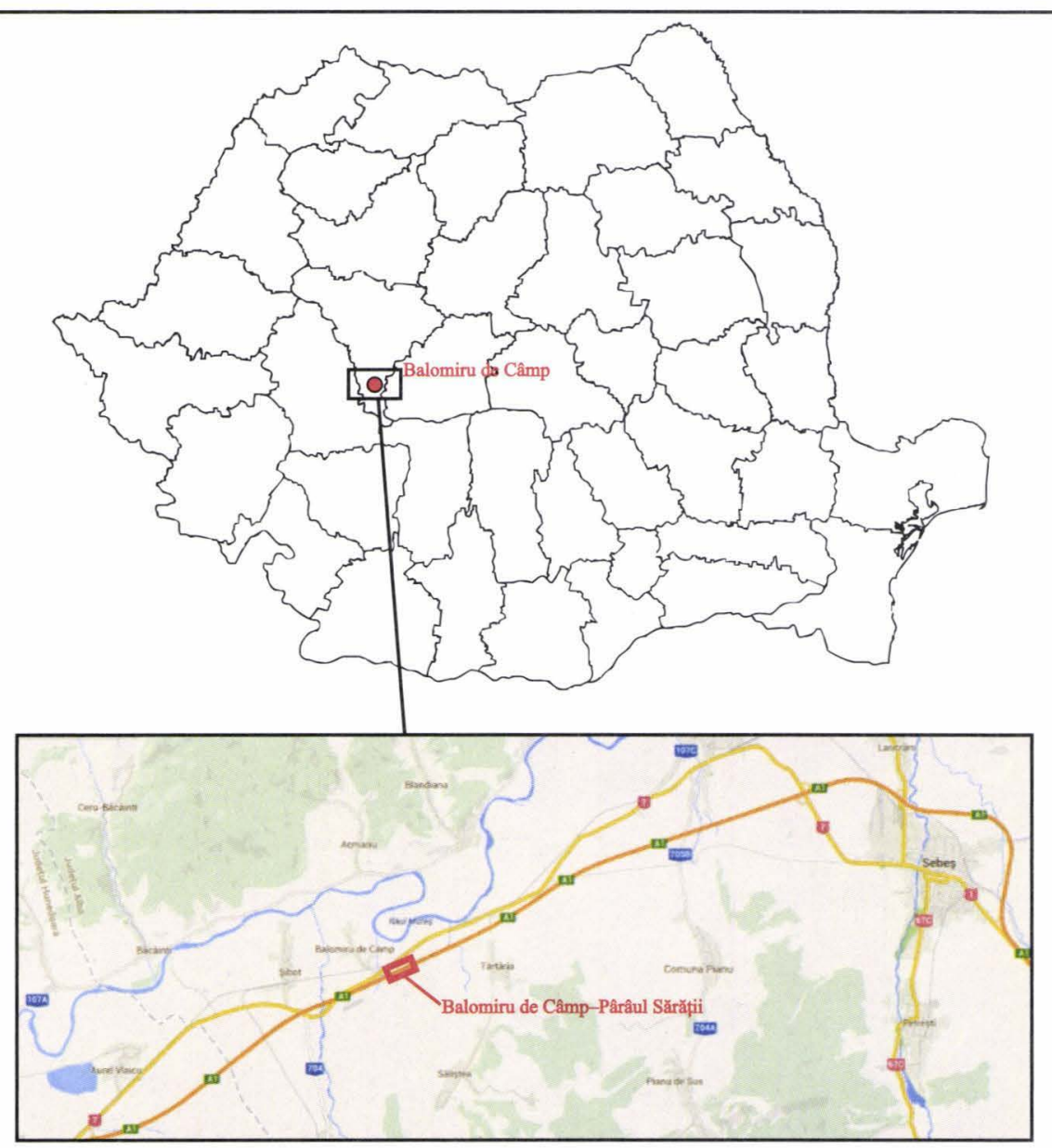

1.

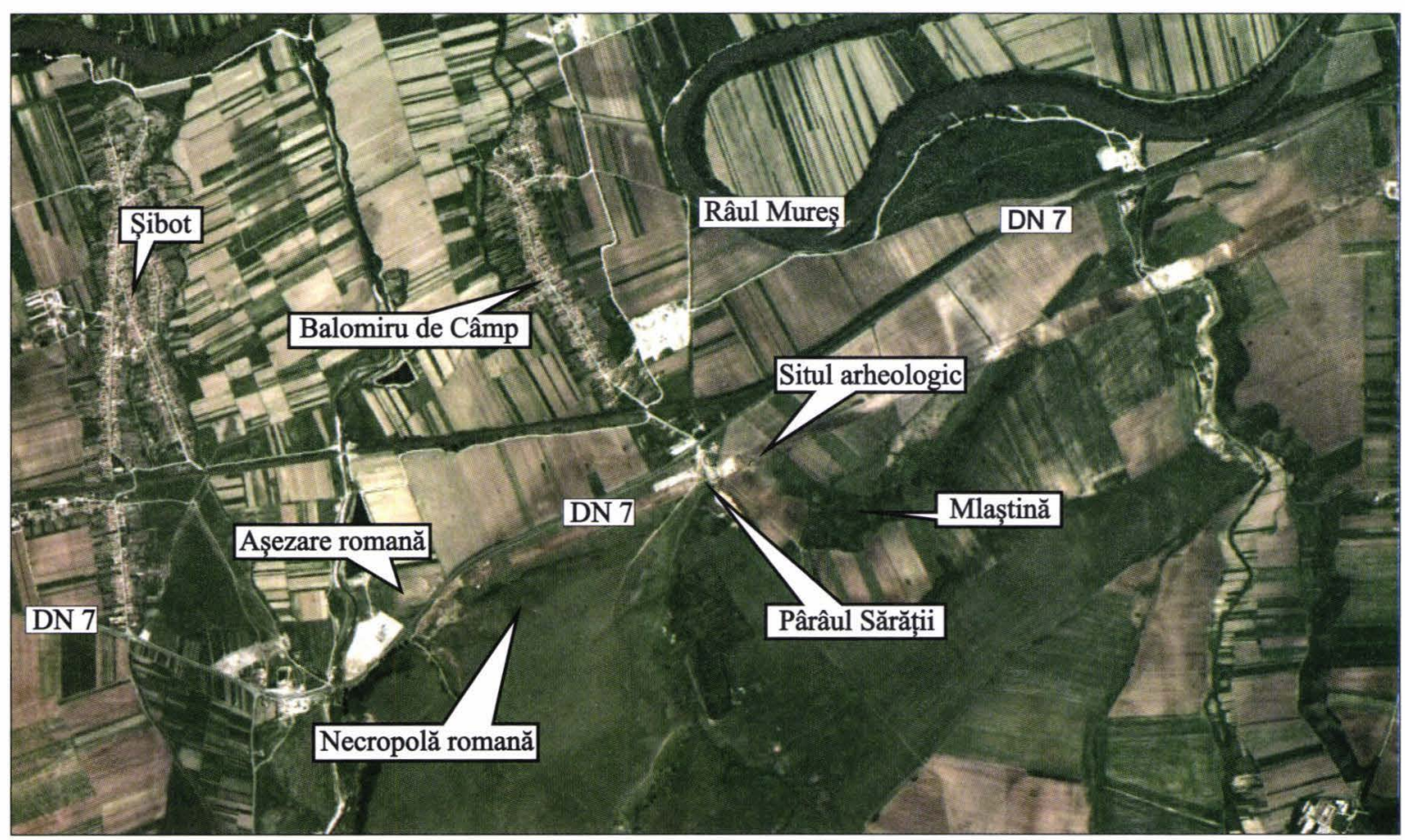

2.

Localizarea pe harta României a sitului arheologic de la Balomiru de Câmp: 1. Vedere generală (Google Maps); 2. Detaliu (hărți opensource preluate de la Google Earth) 


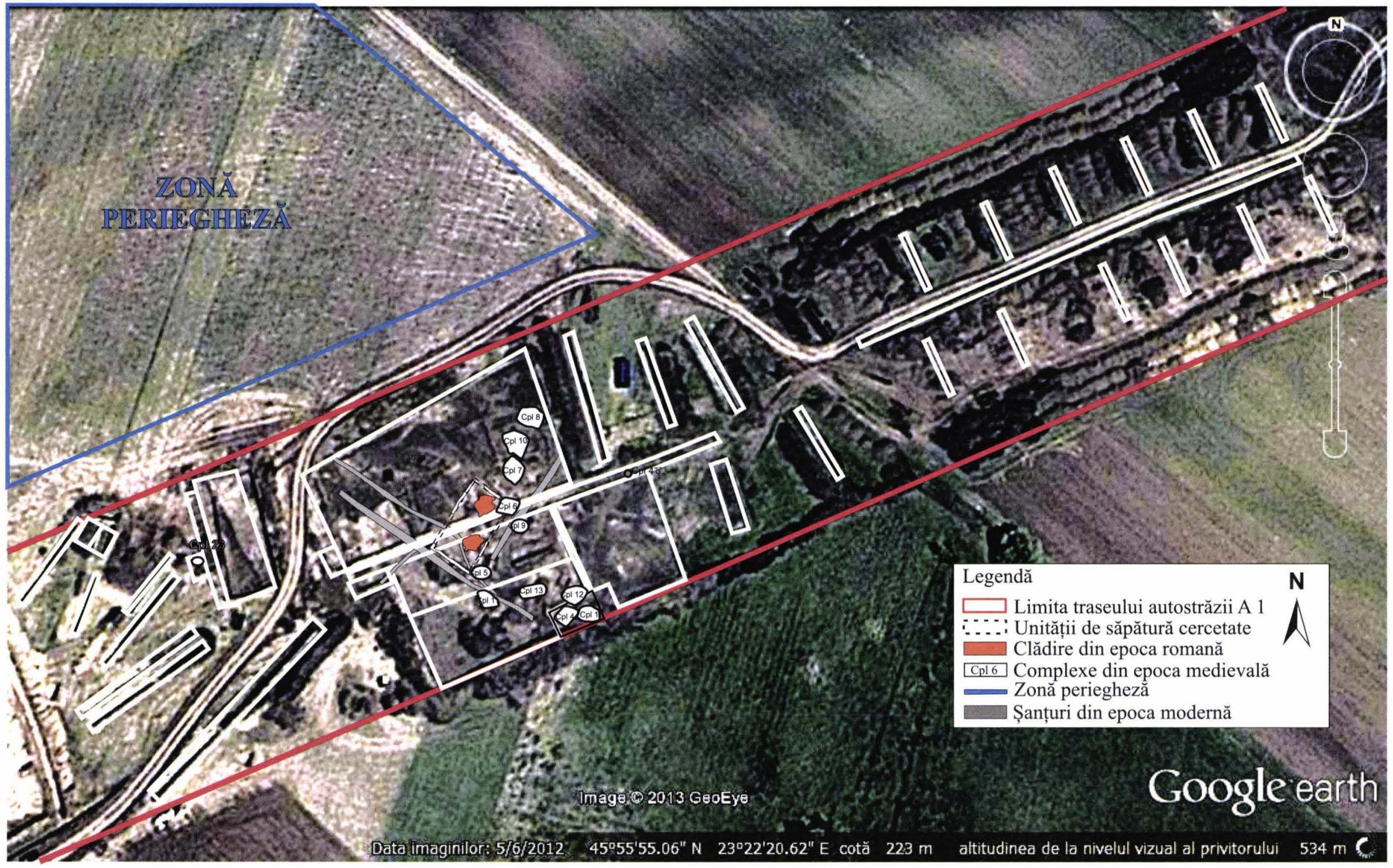

Planul general al cercetării arheologice de la Balomiru de Câmp suprapus pe o fotografie satelitară (foto Google Earth) 


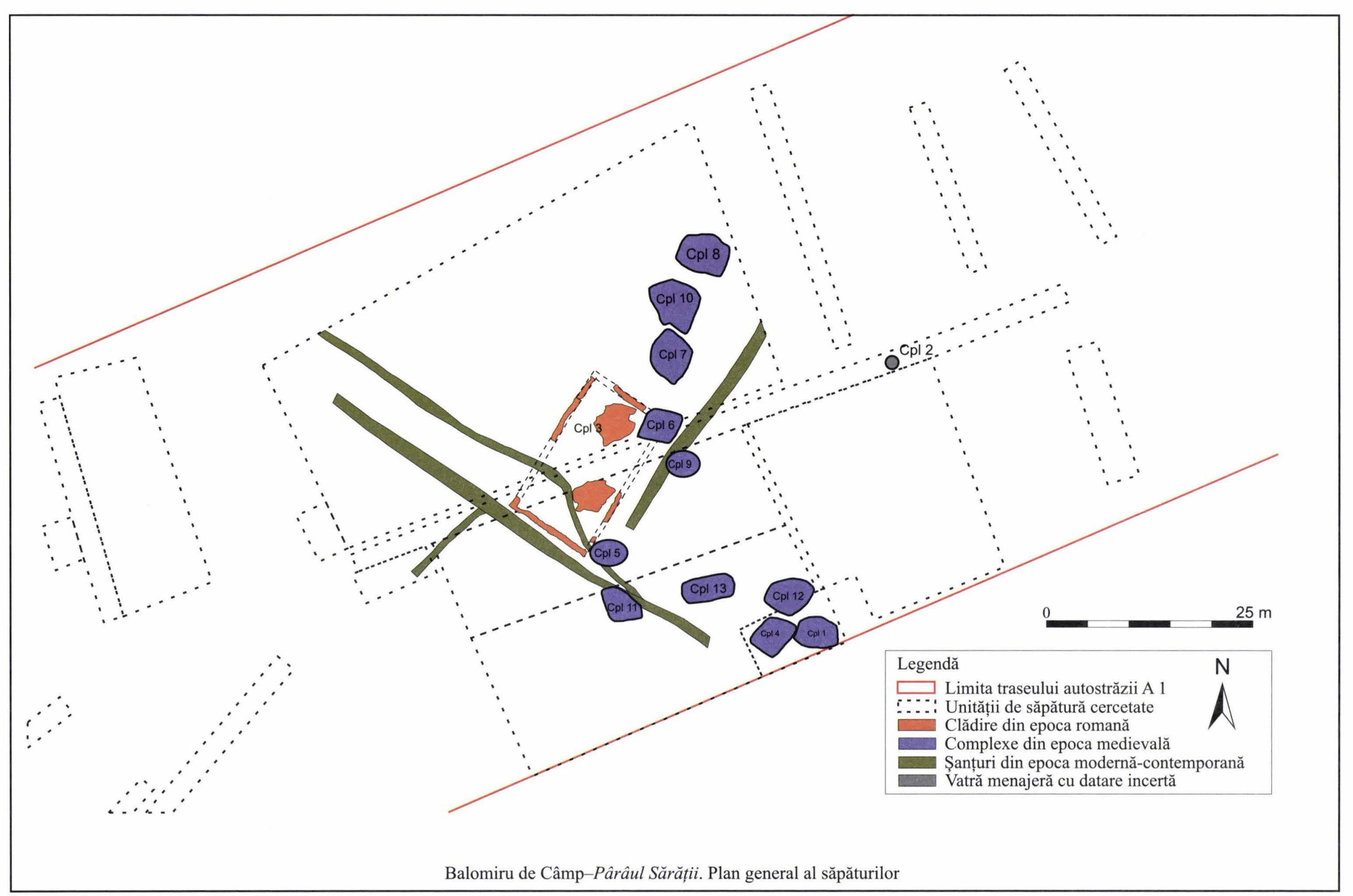




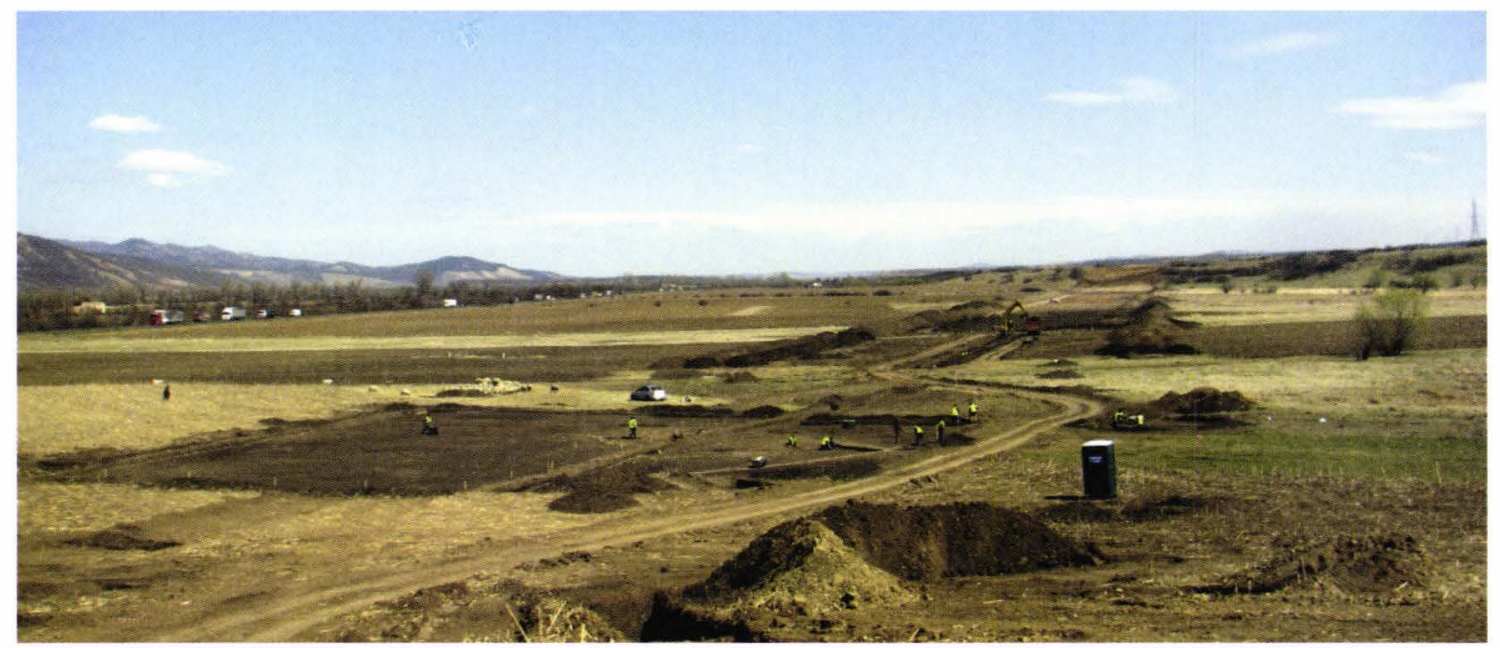

1.
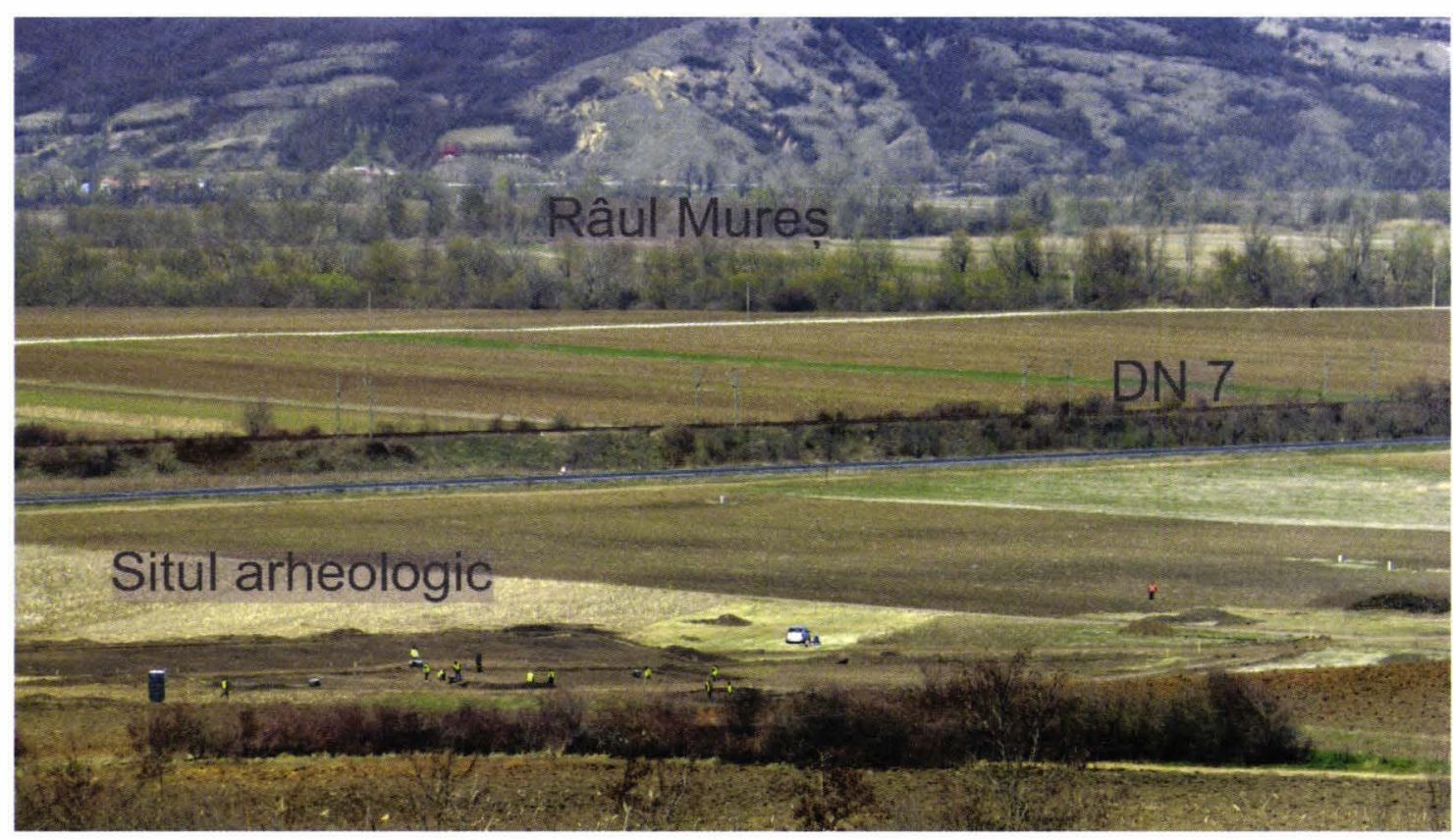

2.

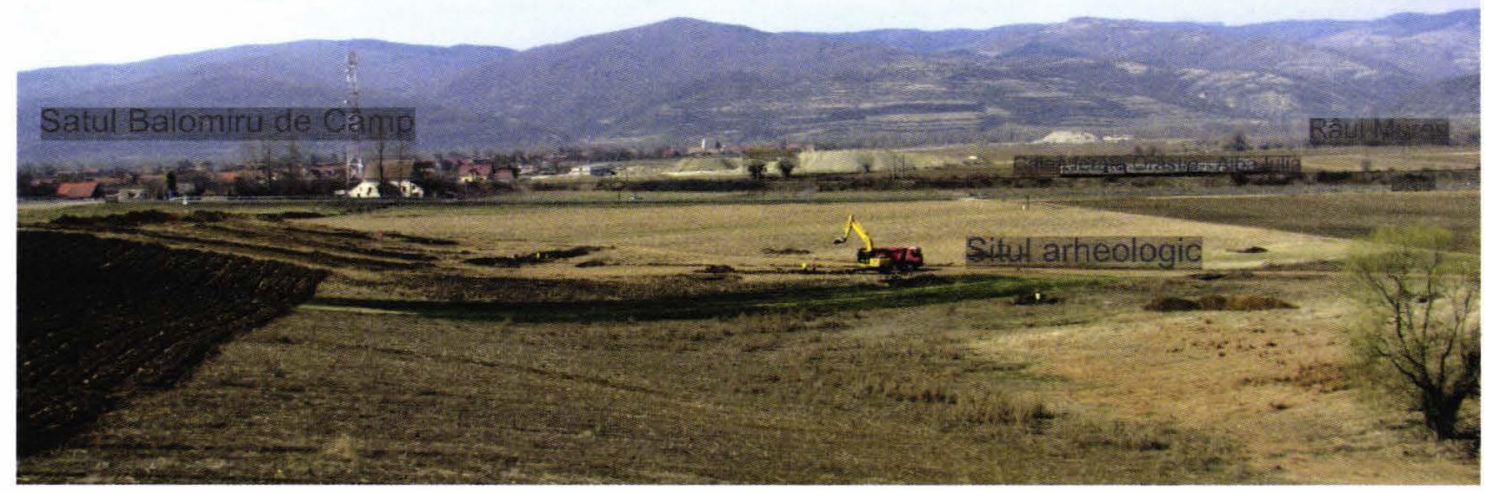

3.

1. S 010 și S 015 - vedere panoramică; 2-3. Vederi de ansamblu ale sitului 


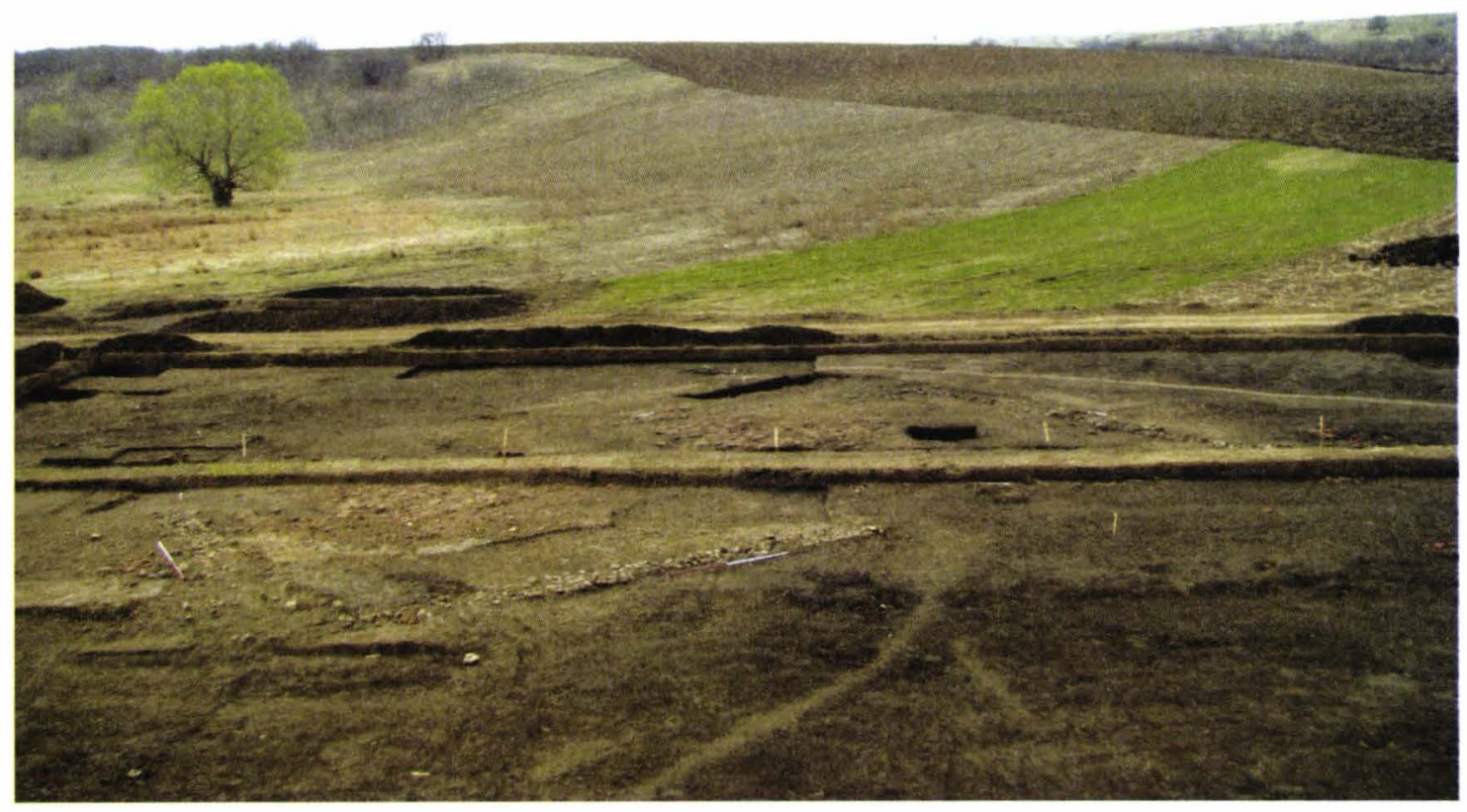

1.

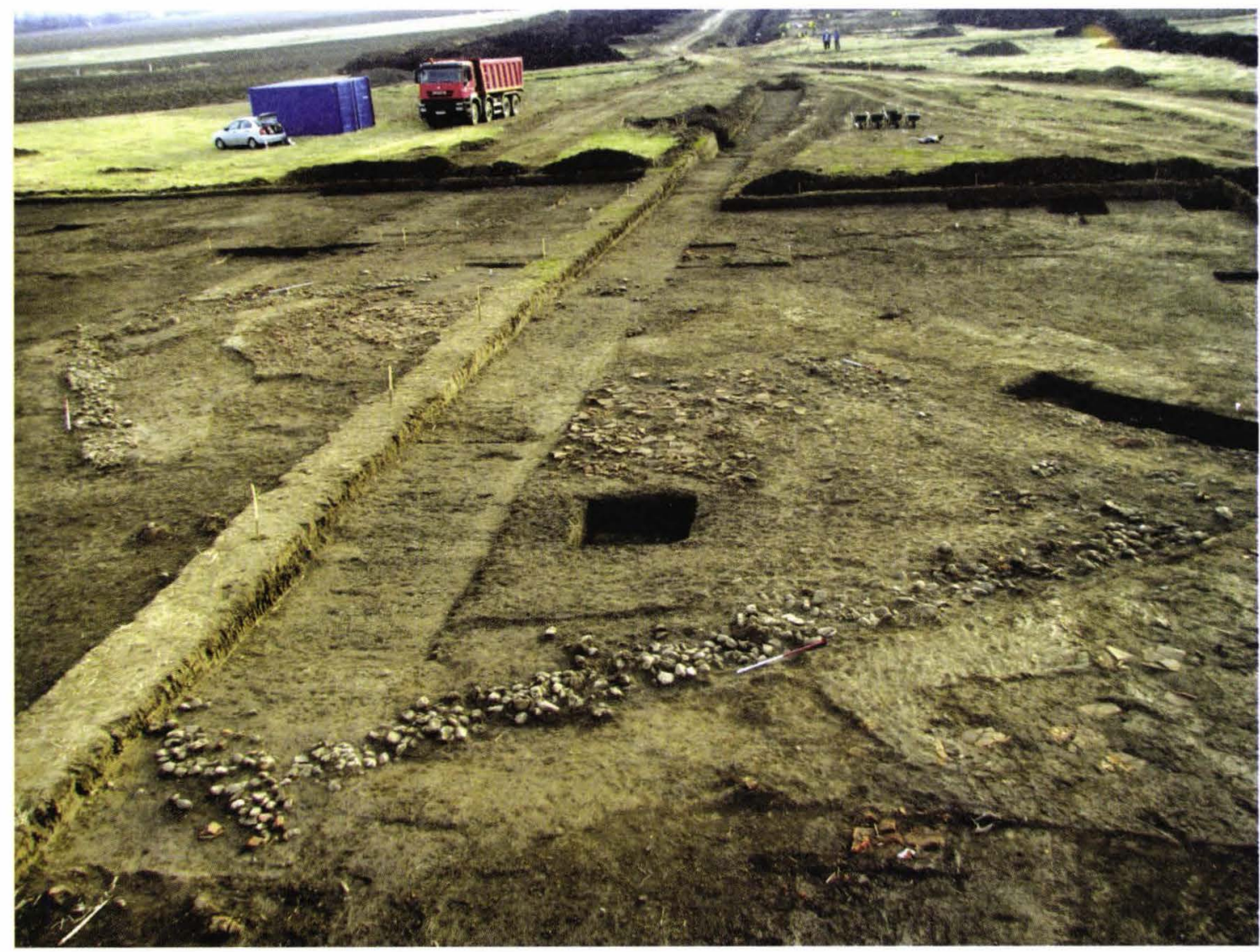

2.

1. Cpl 4 - vedere dinspre N; 2. Cpl 3 - vedere dinspre V 


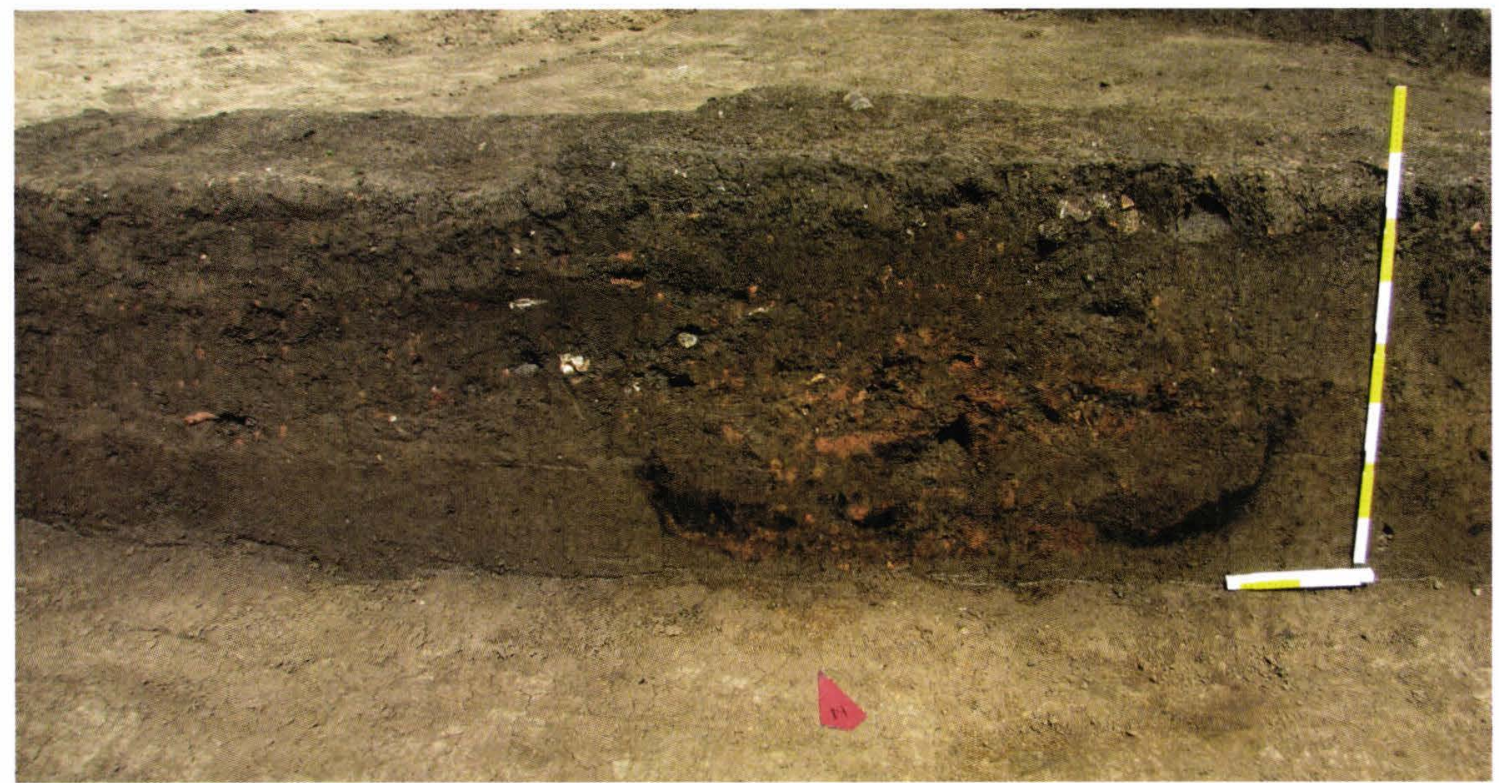

1.

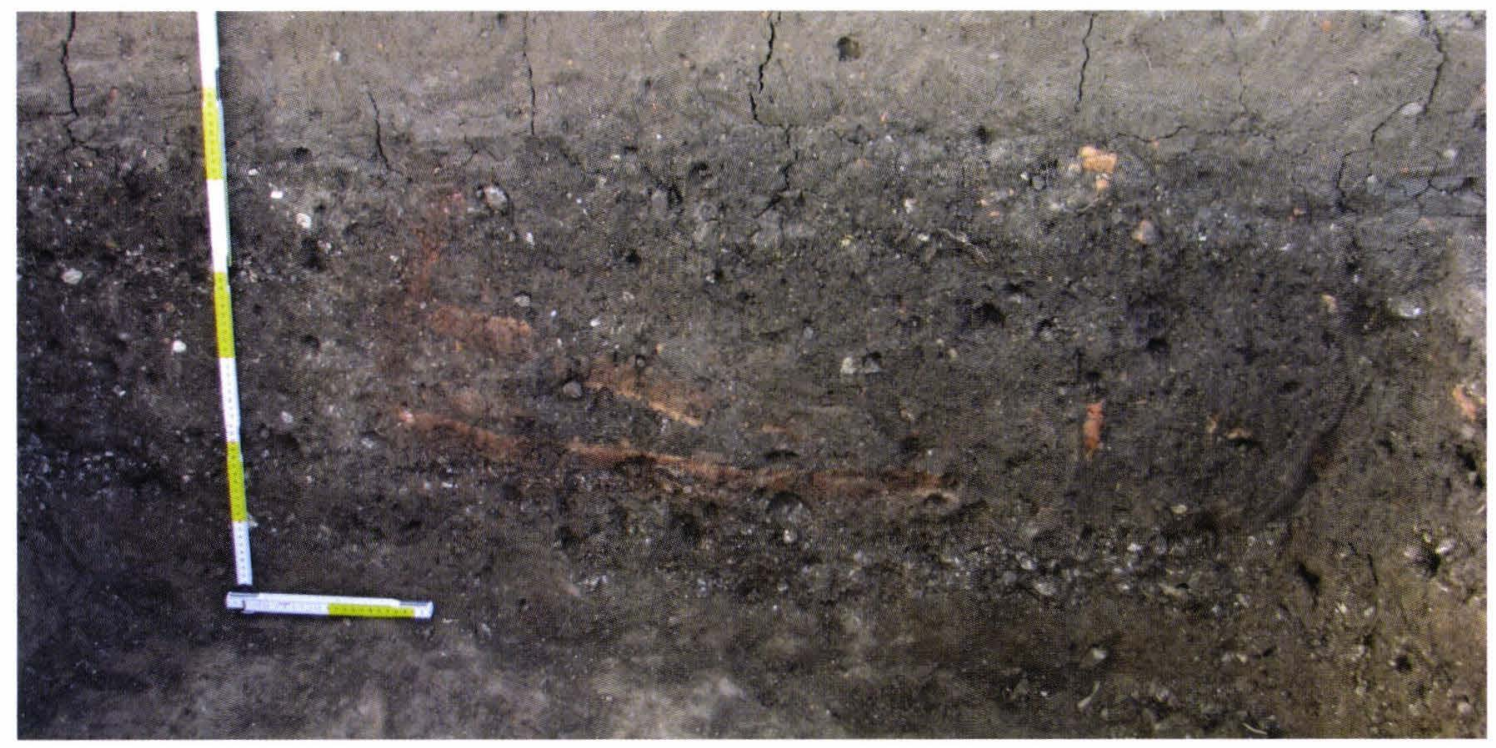

2.

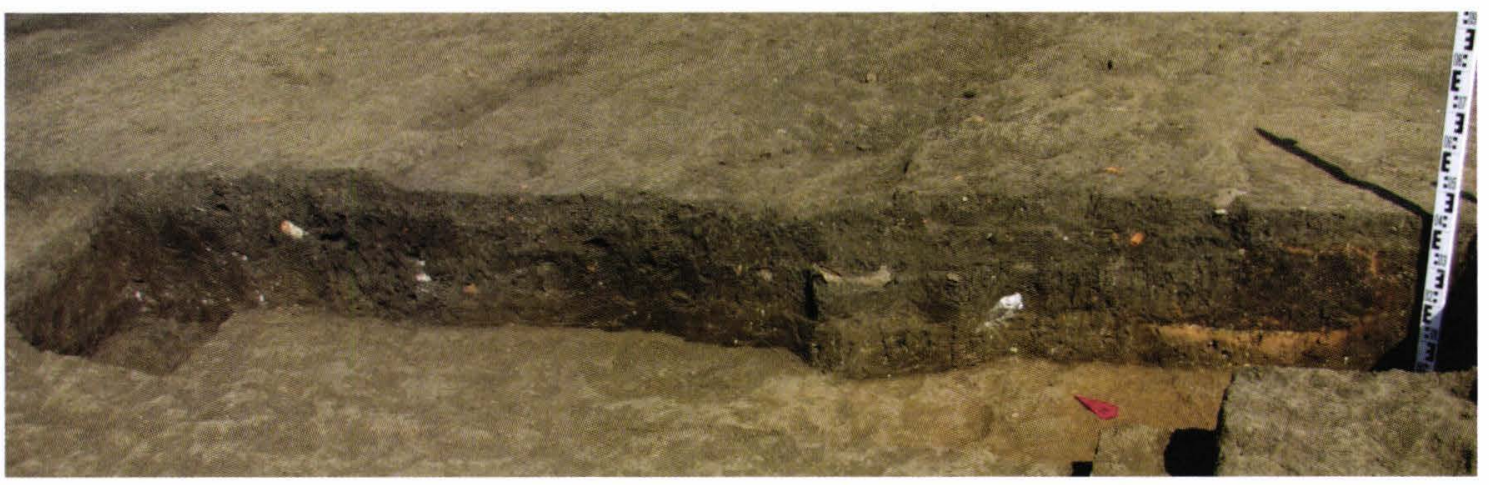

3.

1. Cpl 9 - profil vatră; 2. Cpl 6-profil vatră; 3. $\mathrm{Cpl} 7$-profil 


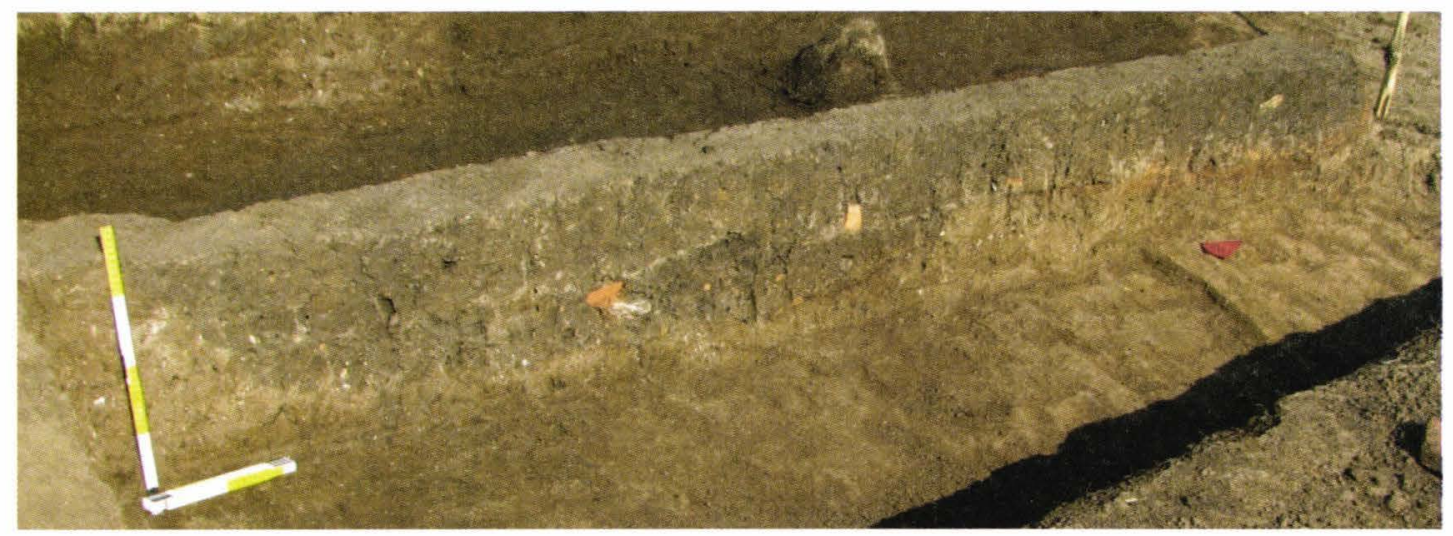

1.

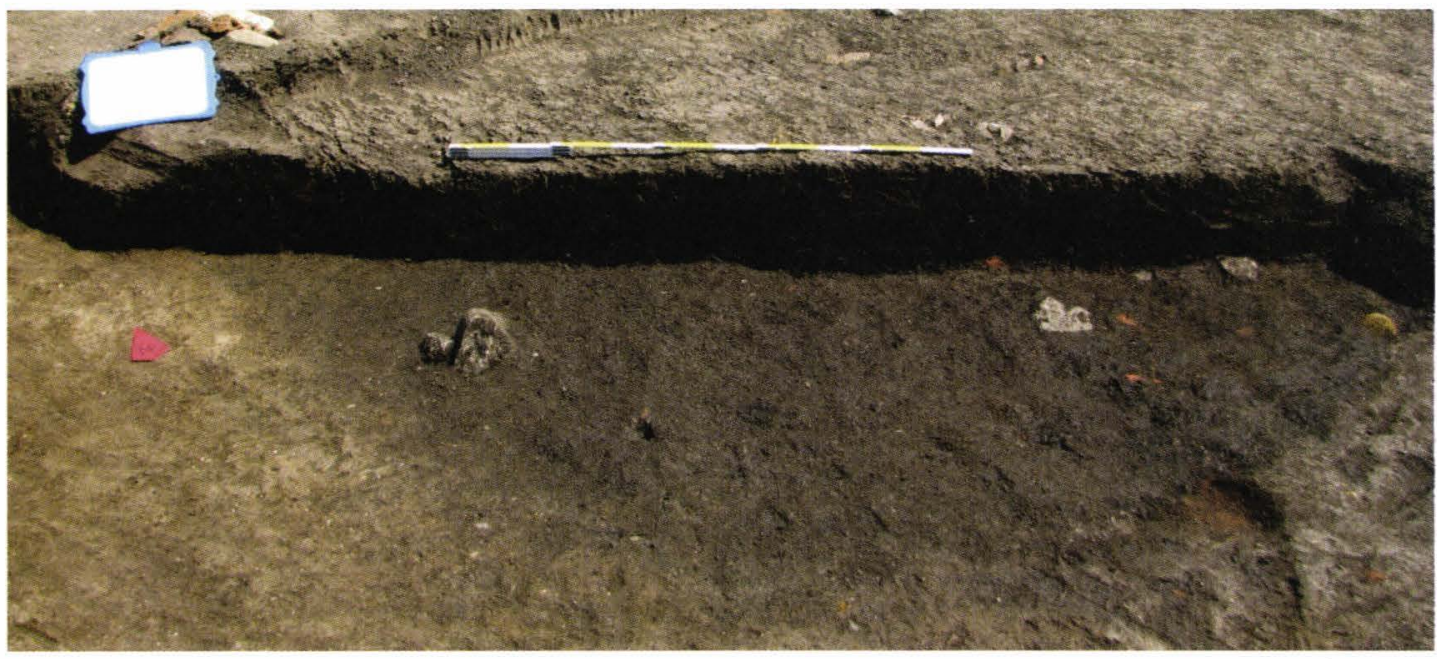

2.

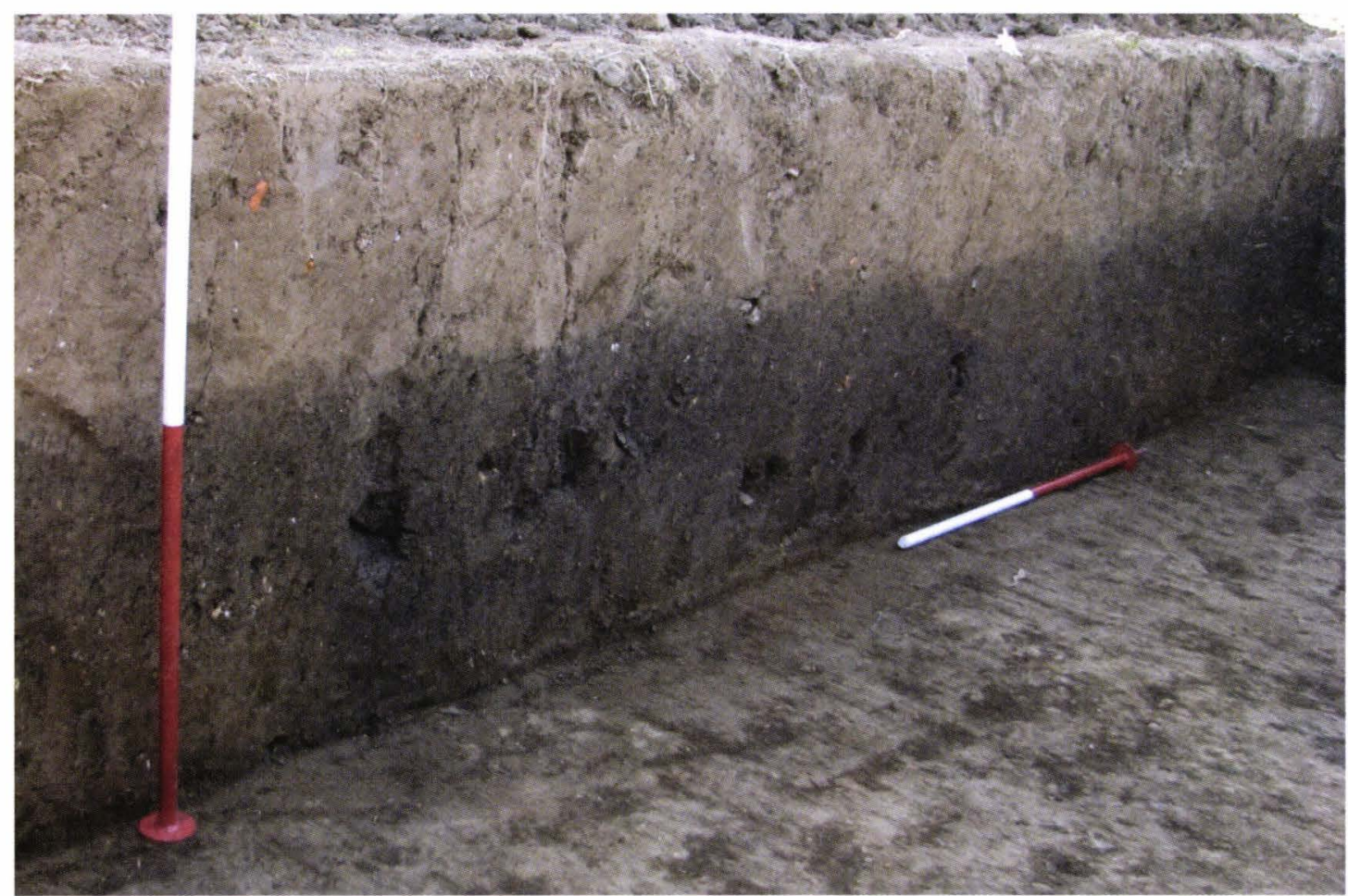

3.

1. Cpl 13 -profil; 2. Cpl 16 -plan; 3. Cpl 1 -profil 


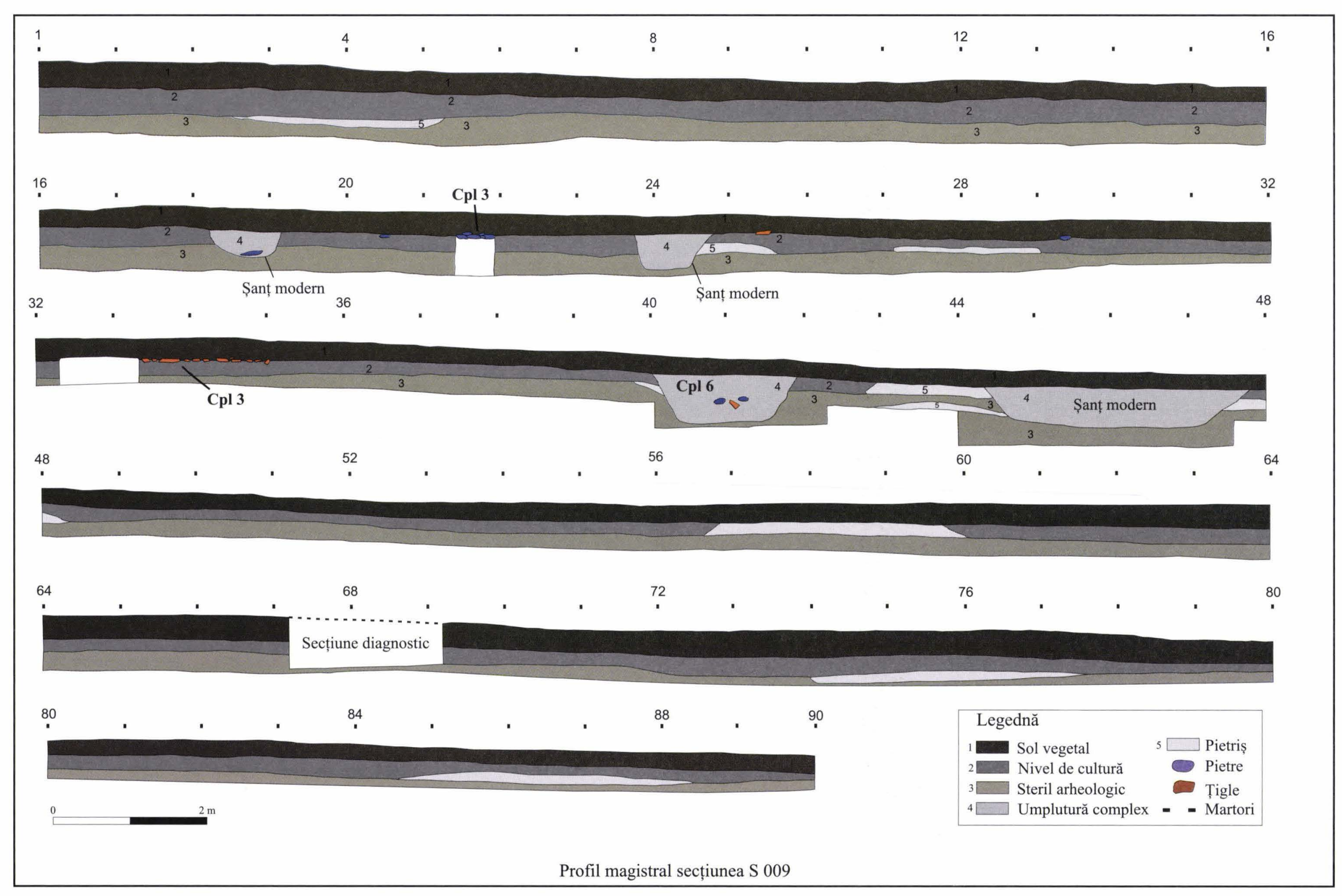




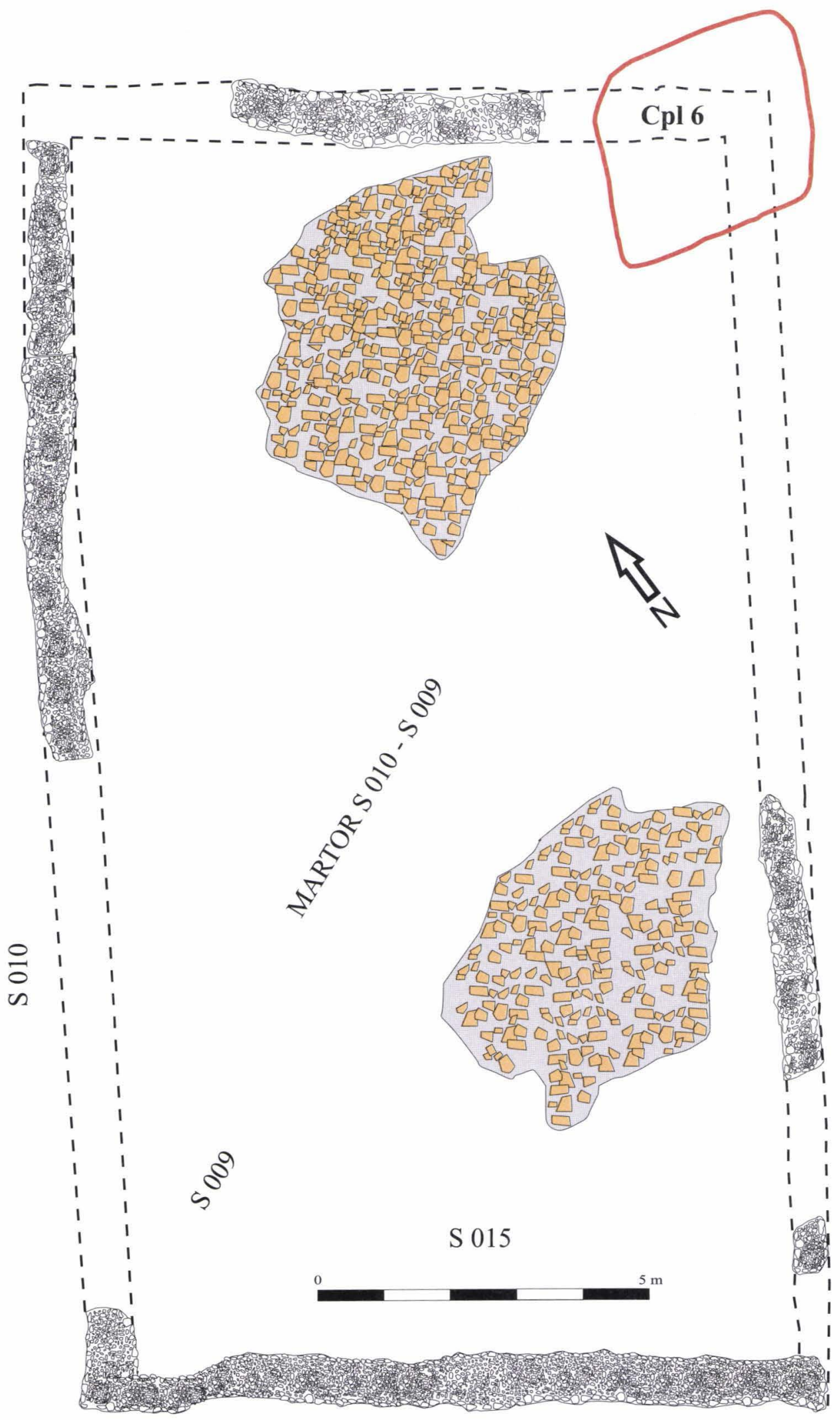

Legenda

Zid din piatră legată cu pământ $\quad \square$ Locuință medievală - Cpl 6

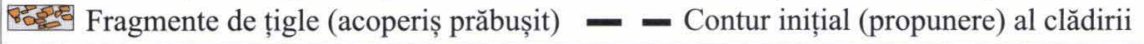

Planul clădirii din epoca romană 


\section{Legenda}

\section{Strat vegetal}

Sediment brun-închis, cu material ceramic

Umplutura locuinței

Steril arheologic

Cuptor menajer

Peliculă de pietriș bogată în calcar

Pietre

Țiglă romană

- Axa de secționare

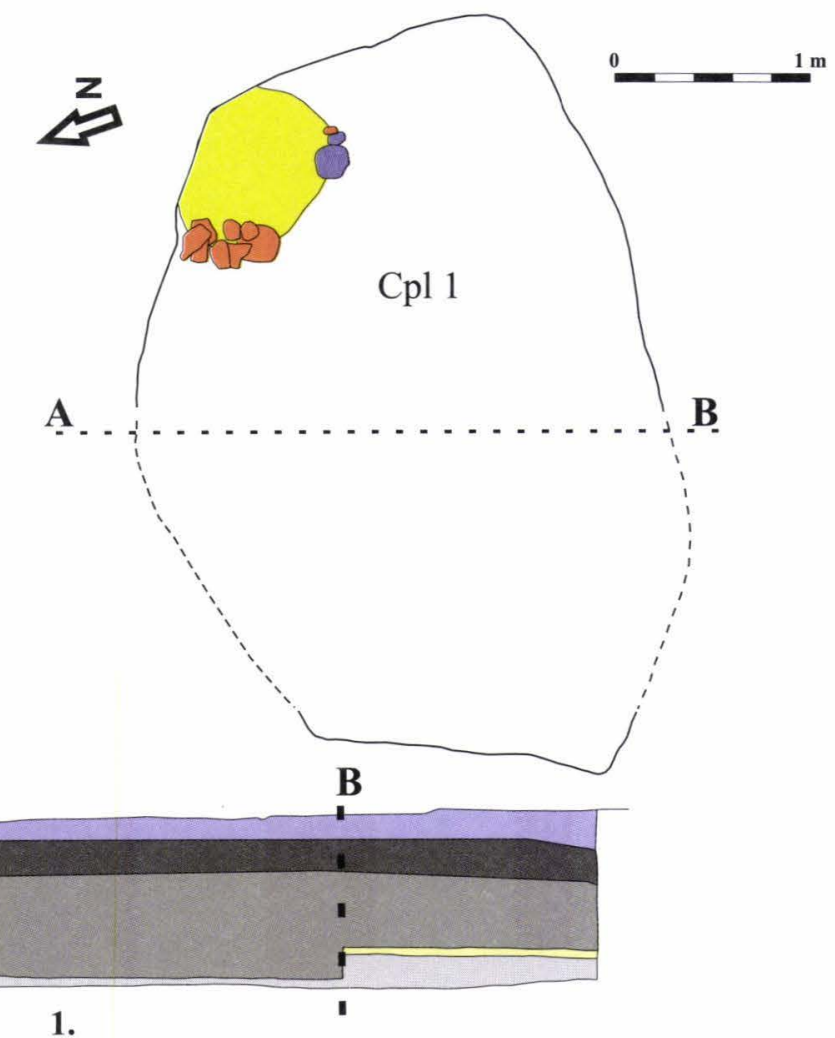

Legenda

Umplutura locuinței

Steril arheologic

Pietre

Tiglă romană

- - Axa de secționare

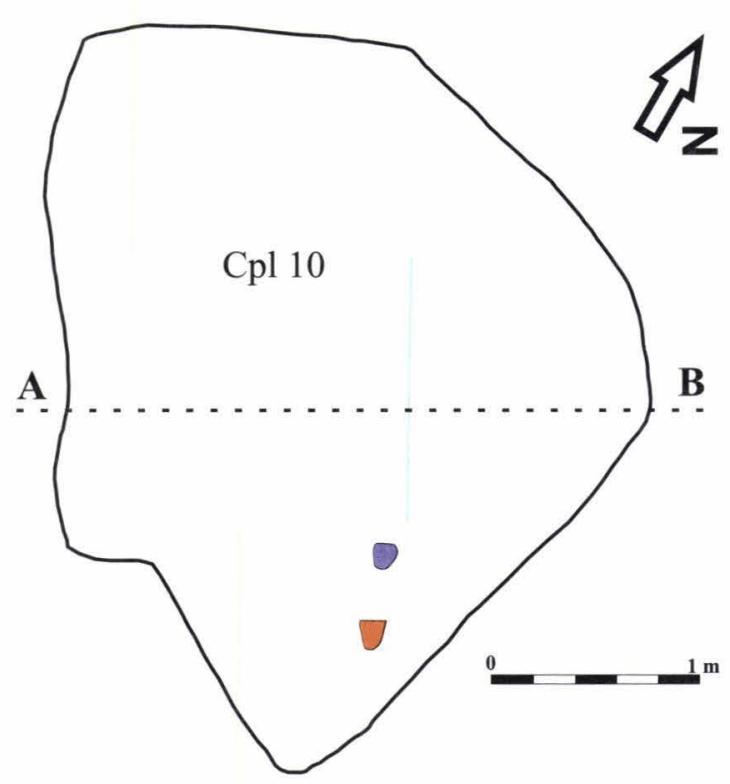

A

B

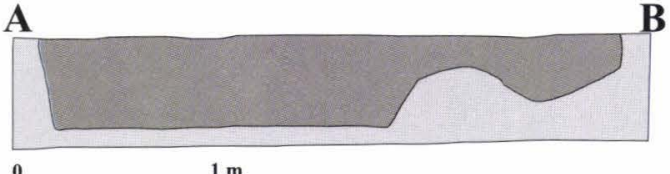

2. 
Sediment brun-închis, bogat în material ceramic Umplutură șanț modern Umplutura Cpl 9 Steril arheologic Nivel de arsură bogat în cărbuni și cenușă Pietre

- Cărămidă romană

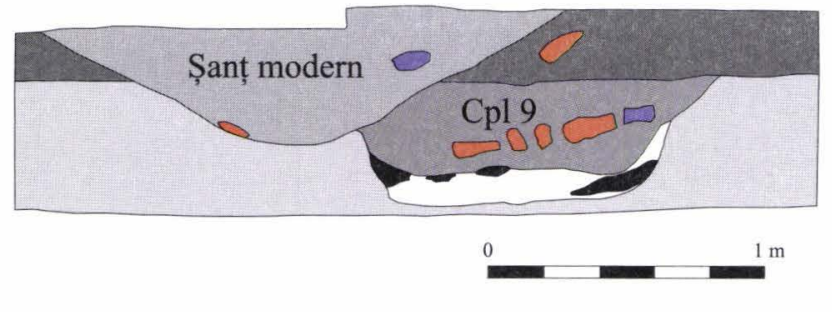

1.

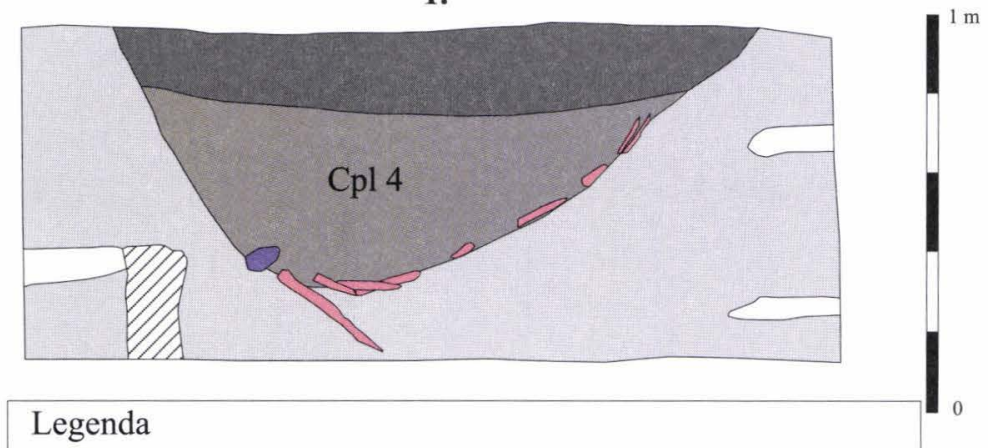

Sediment brun-închis amesteacat cu fragmente ceramice

Sediment brun-negru amesteacat cu fragmente ceramice UZA Galerie de rozătoare

Lentile de pietriș calcaros

Steril arheologic

Pietre

Cărămidă romană (fragment dolium)

2.

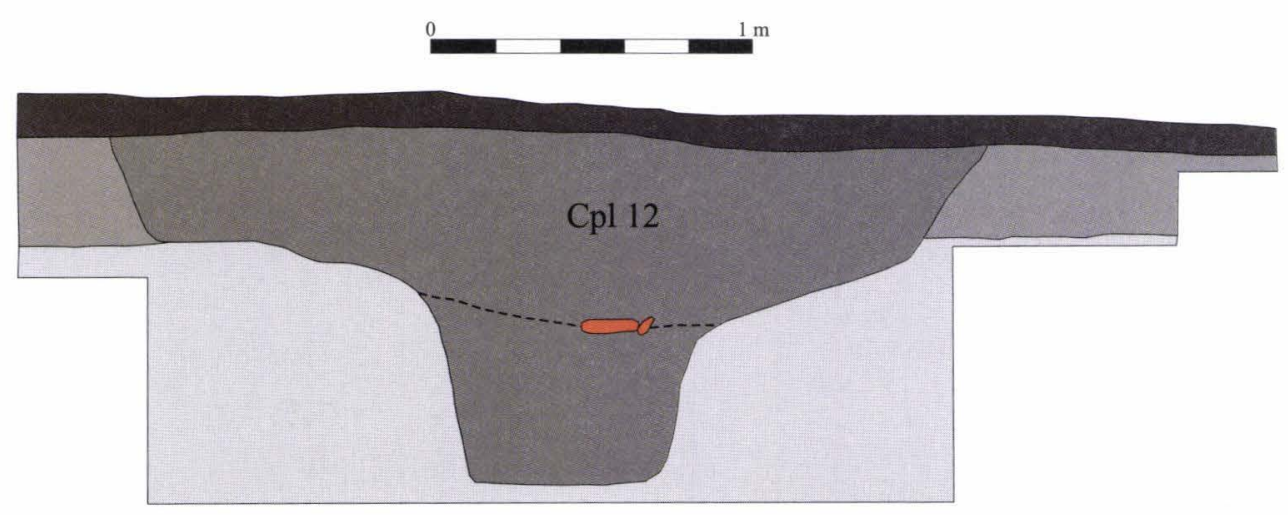

Legenda

Sediment brun-închis, nivel de inundație

Sediment brun-deschi, bogat în pigment ceramic și cărbune

Sediment brun-negricos, bogat în pietre de dimensiuni mici și pigment ceramic Steril arheologic

Cărămidă romană 


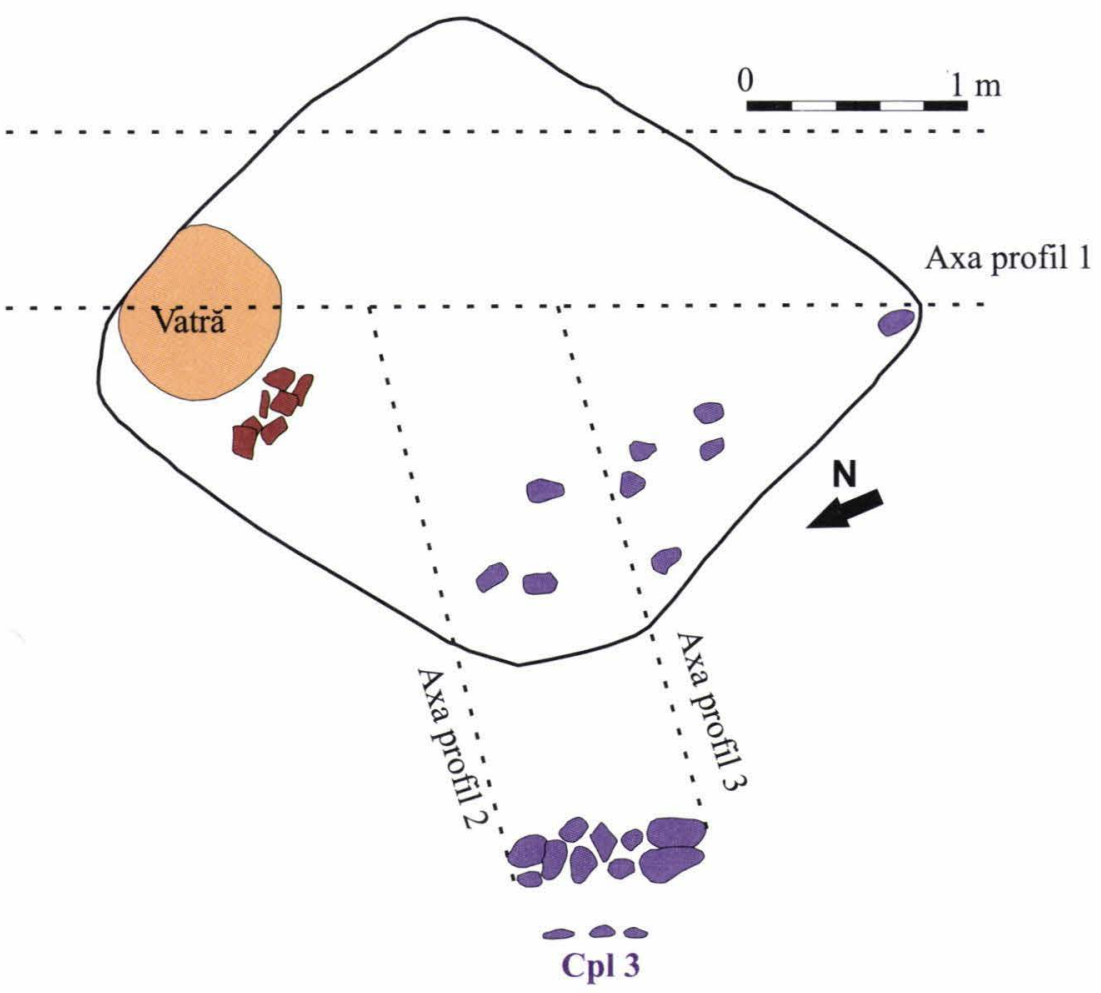

Profil 1

NE

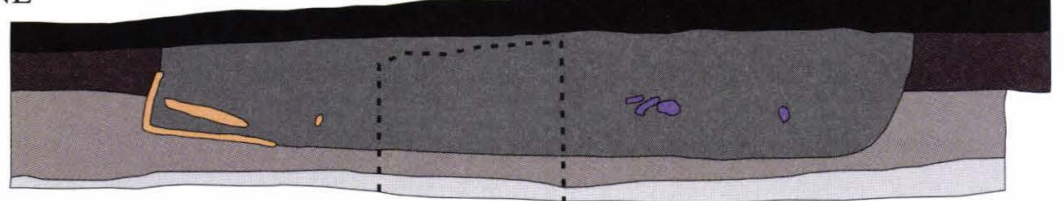

$0 \quad-\quad 1 \mathrm{~m}$
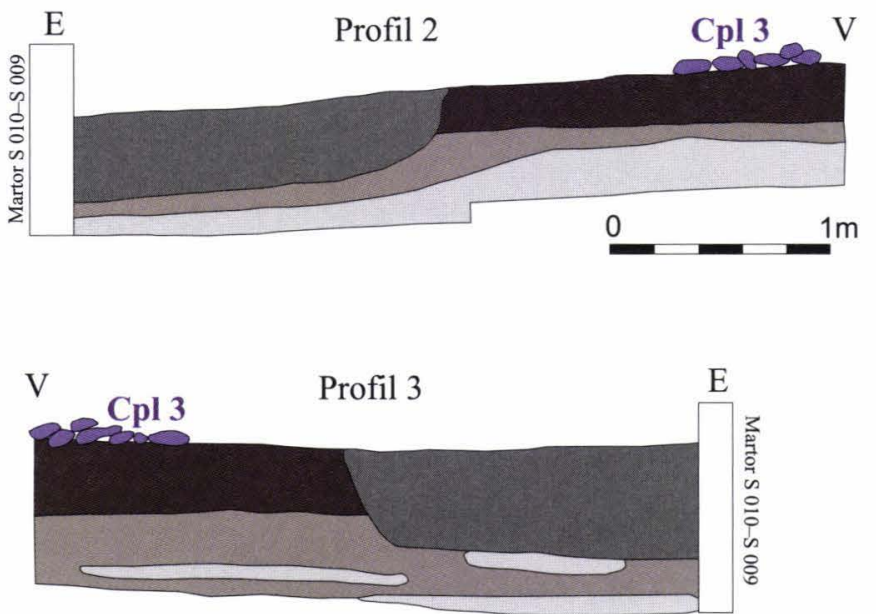

Legenda

Strat vegetal

Strat cu material roman

Steril arheologic

Umplutura locuinței

Pietriș

$\leftrightharpoons$ Cuptor menajer

$1-1 m$

- Martori - axe de desen

Cpl 6 - plan și profile 
Legenda

Nivel de inundație

Umplutura locuinței

Steril arheologic

$\Longleftarrow$ Oase

$\Longleftarrow$ Cuptor menajer

Pietre

Cărbune

- - Axa de secționare

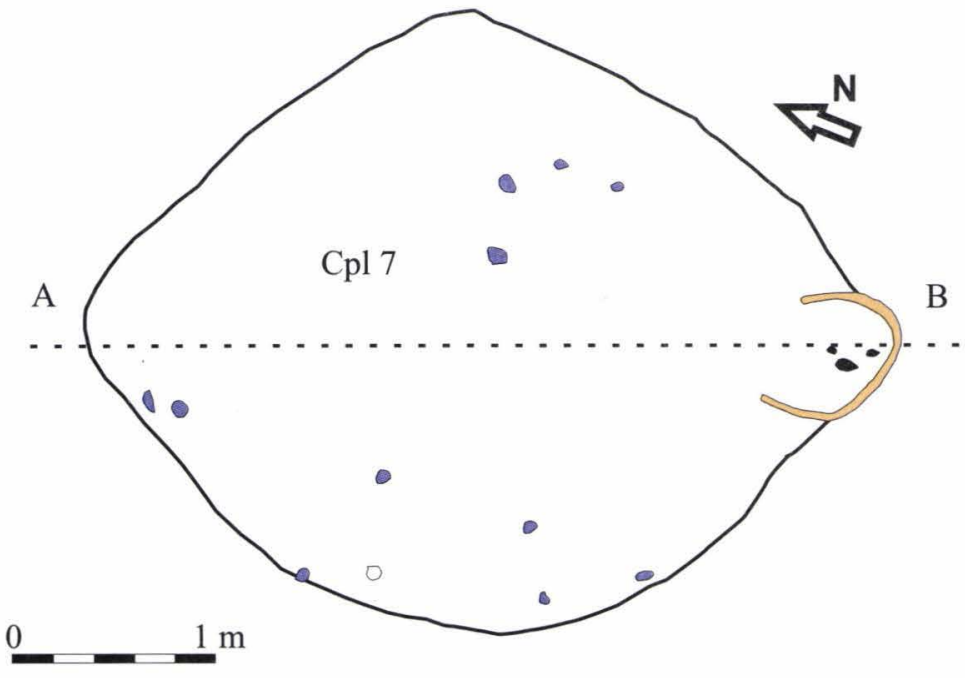

B

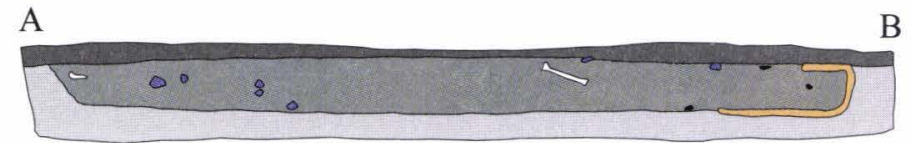

1.

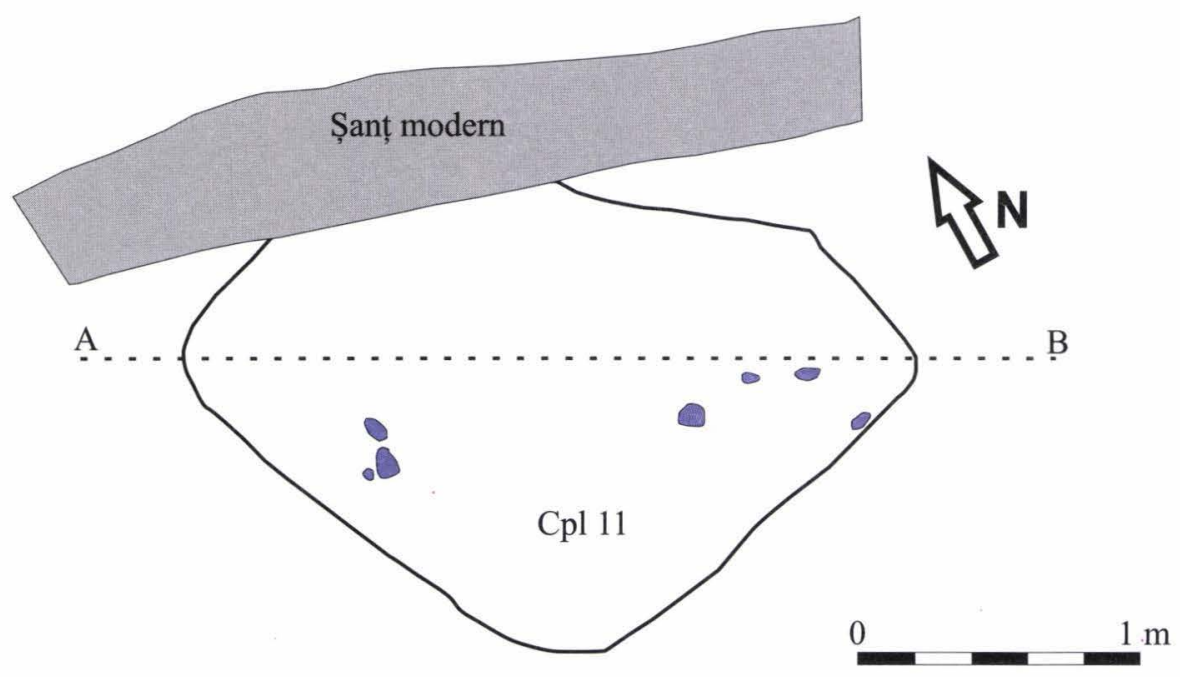

Legenda

Nivel de inundație

A

B

Umplutura locuinței

Steril arheologic

Pietre

$\therefore$ Cărbune

- . - Axa de secționare

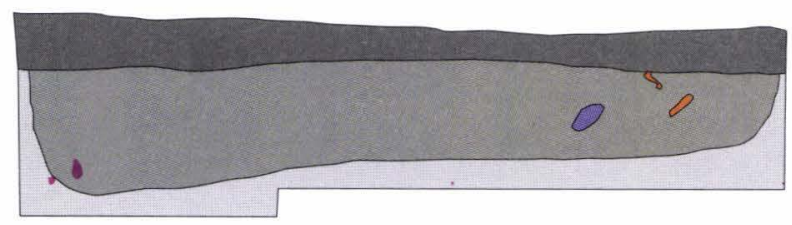

2.

1. Cpl 7 -plan și profil; 2. Cpl 11 - plan și profil 


\begin{tabular}{|l|}
\hline Legenda \\
Umplutura cuptorului \\
Umplutura gropii \\
Steril arheologic \\
Pereții cuptorului \\
Pământ ars \\
Pietre \\
- Cărbune \\
\hline - Axa de secționare
\end{tabular}
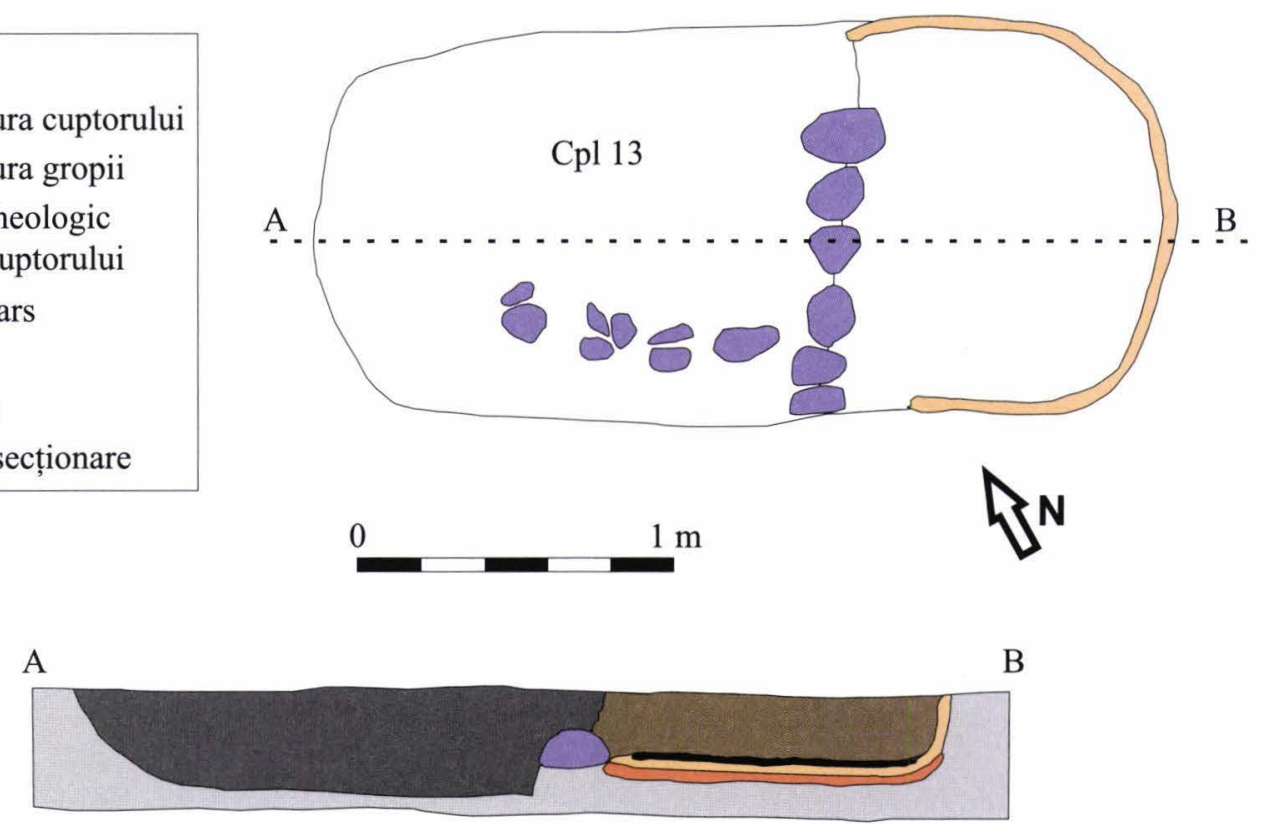

B

1.

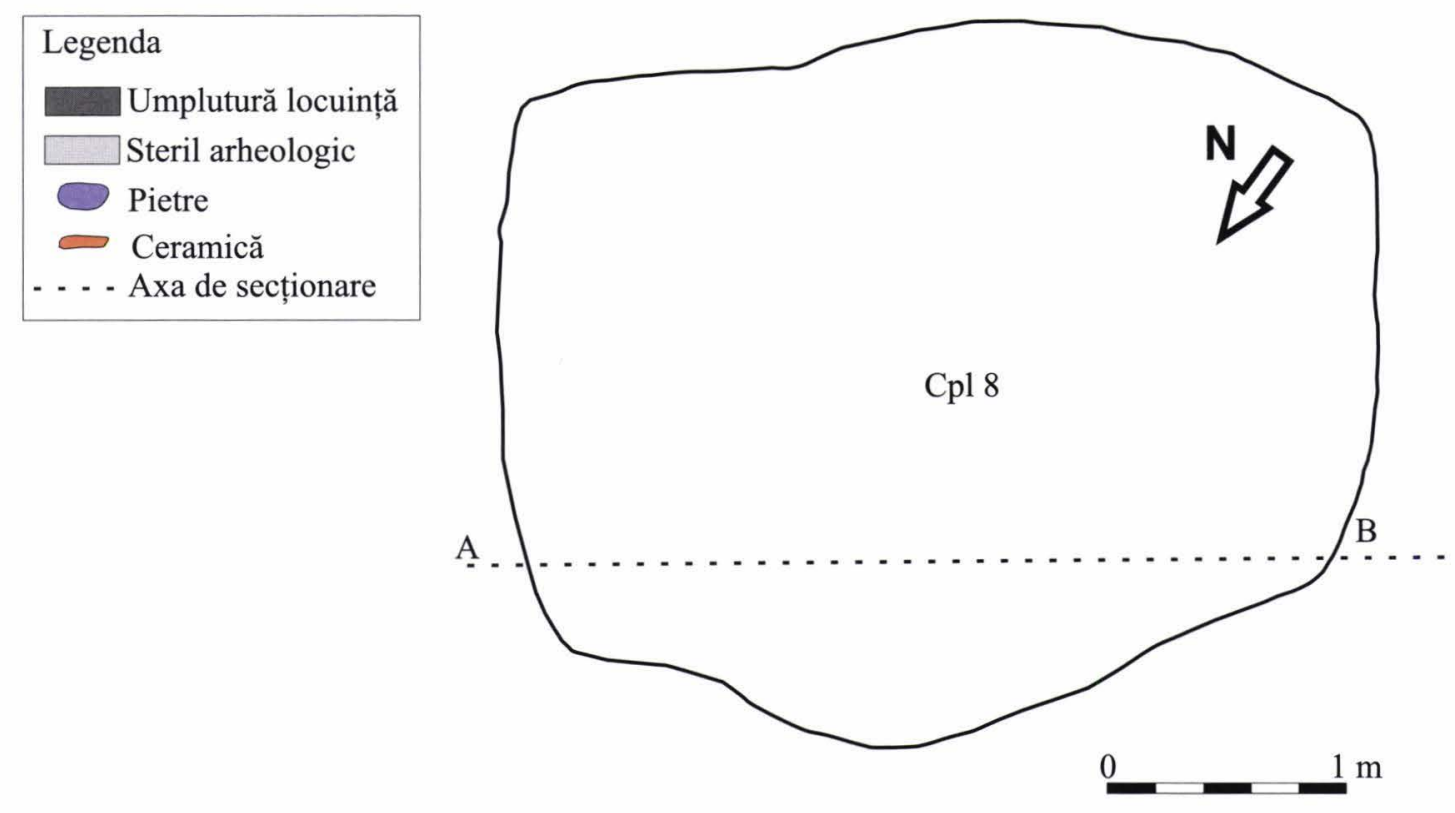

A

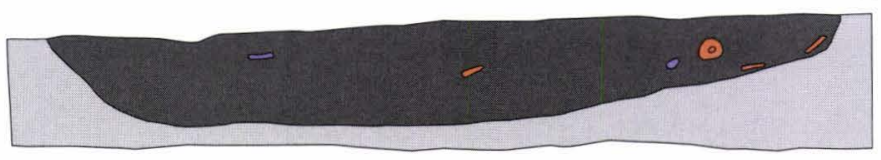

2.

1. Cpl 13 - plan și profil; 2. Cpl 8 - plan și profil 

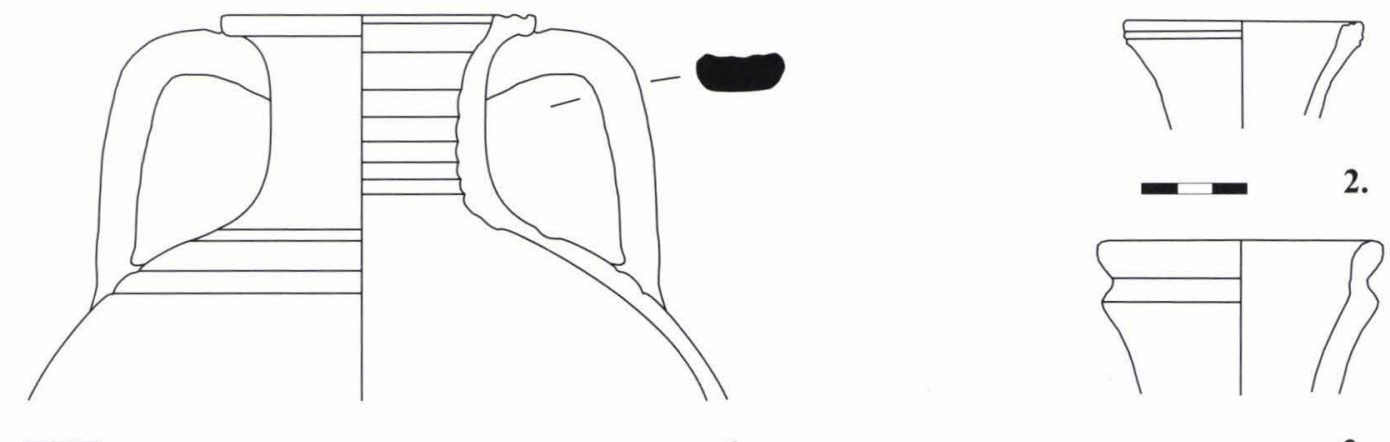

1.

3.
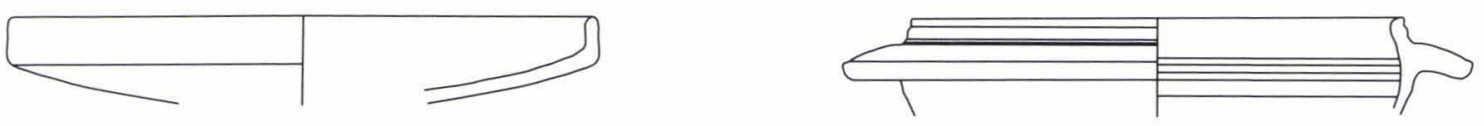

4.
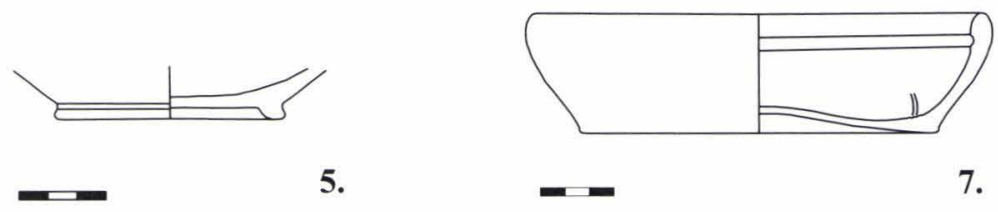

5.

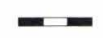

7.
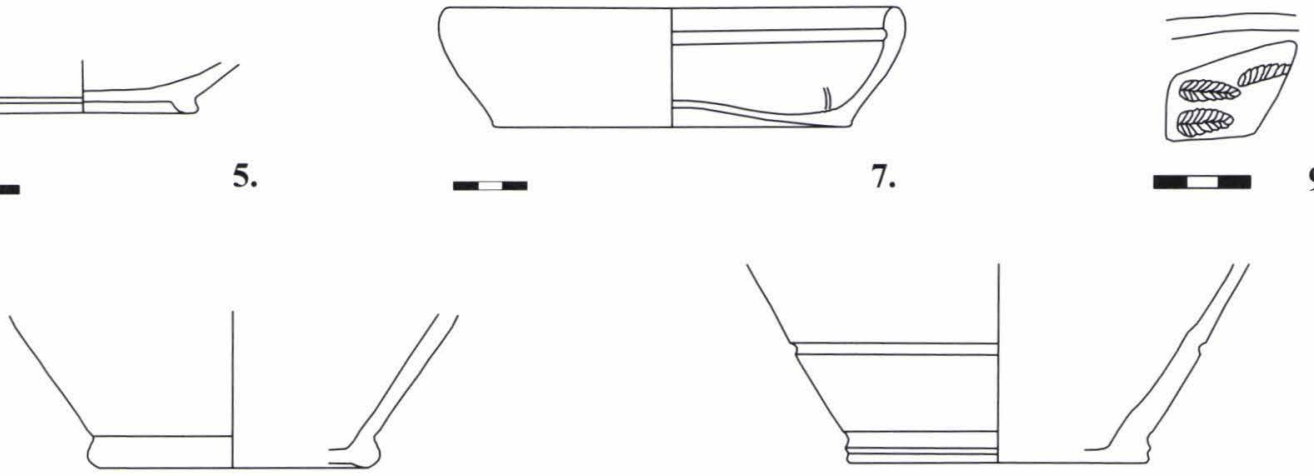

-

9.

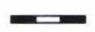

10.

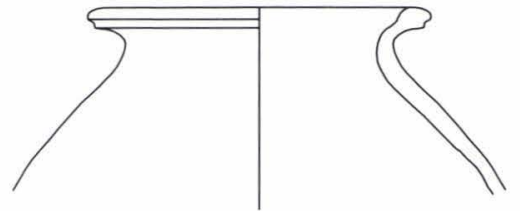

11.
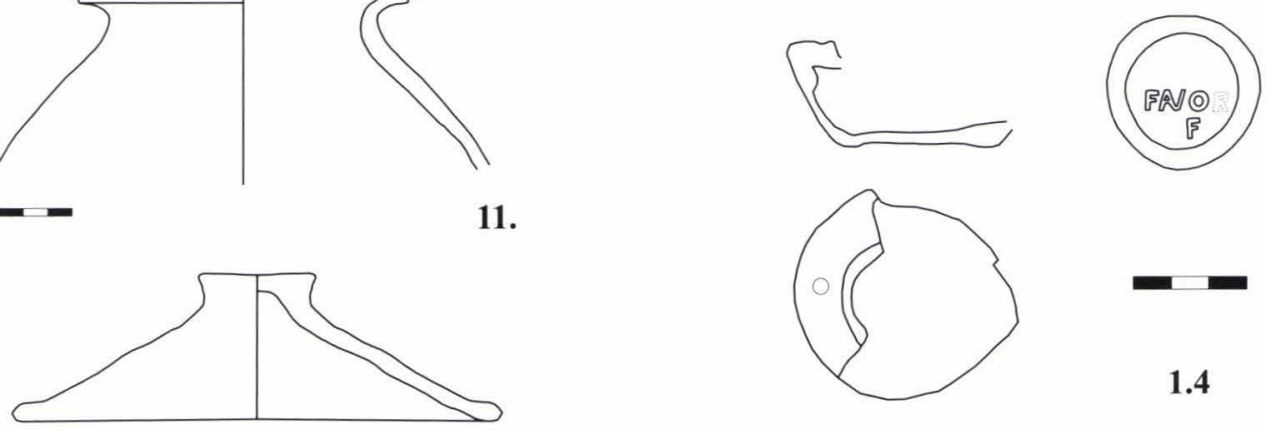

$-$

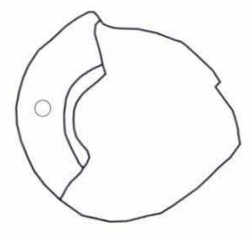

1.4

12.
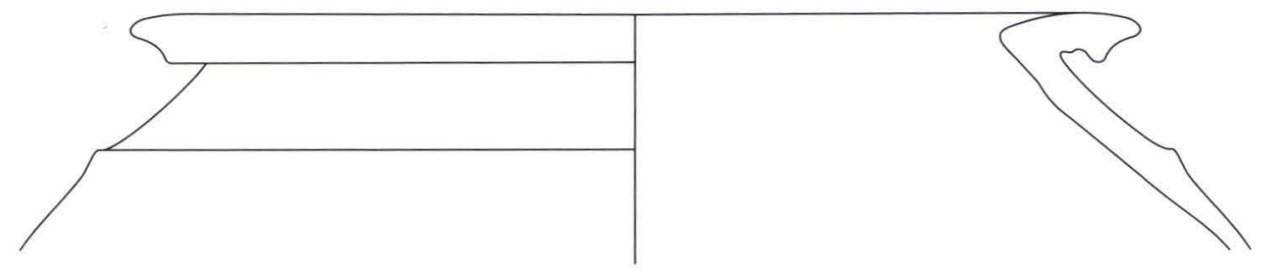

13.

Ceramică romană

Pl. XV 


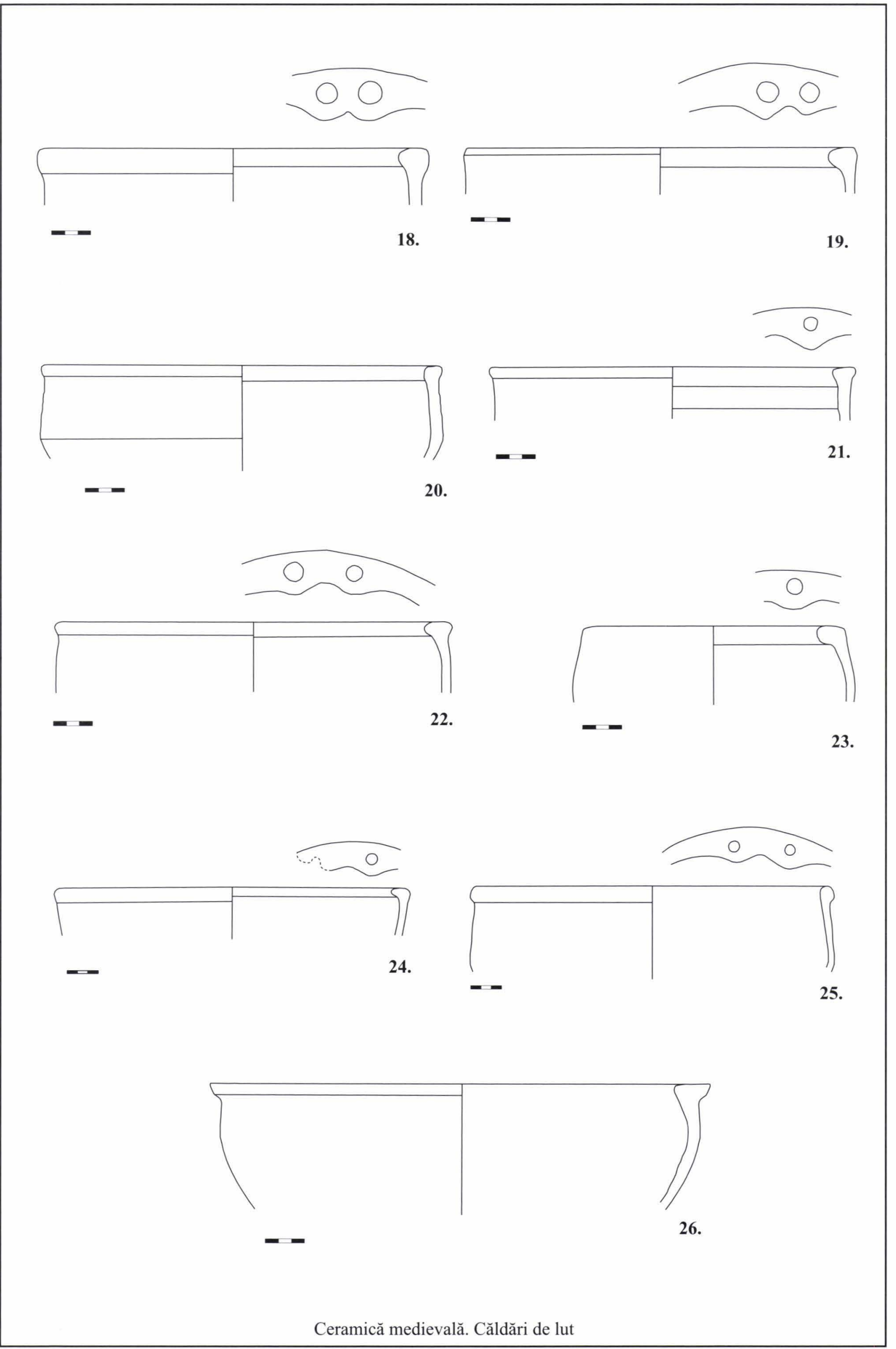

PI. XVI 


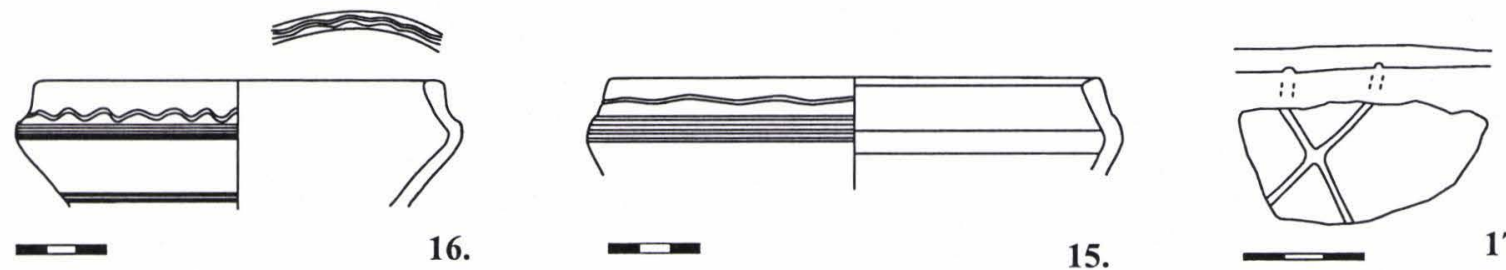

17.

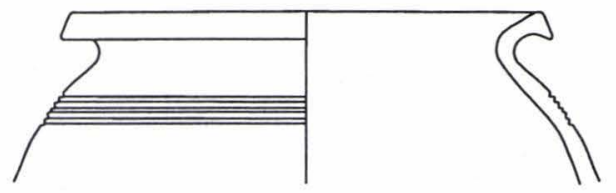

27.
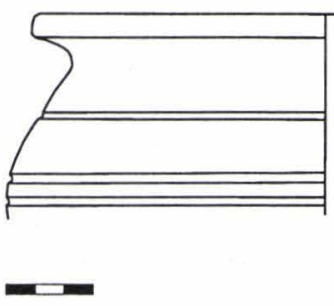

29.
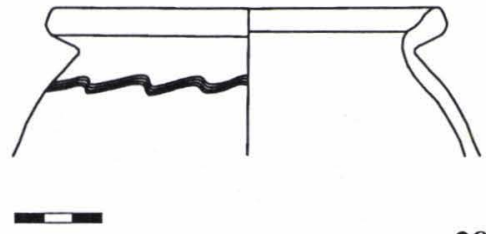

28.

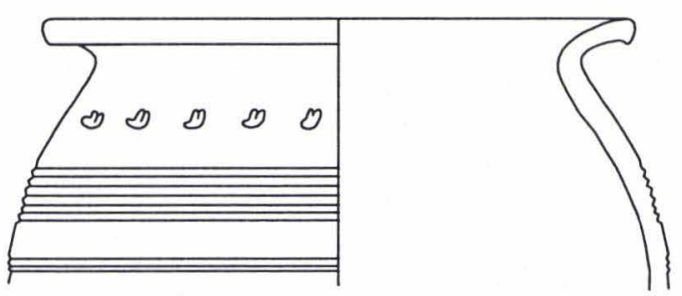

$-2$

30.

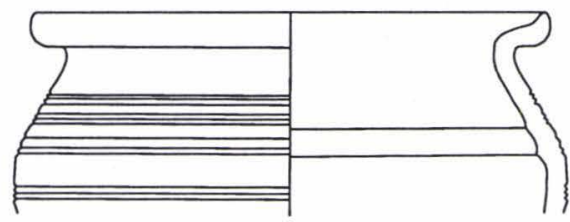

31.

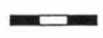

32.
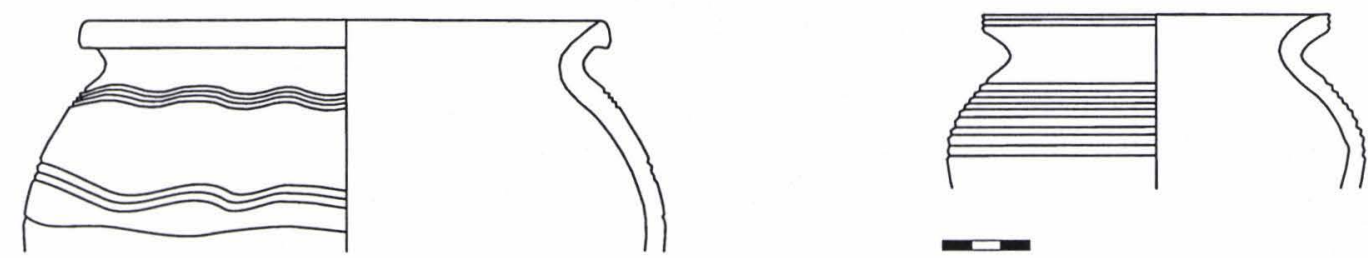

33.

34.
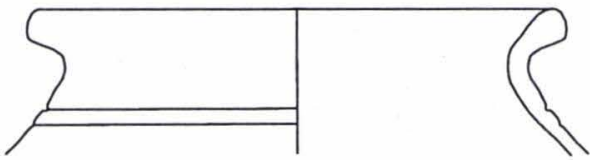

35. 

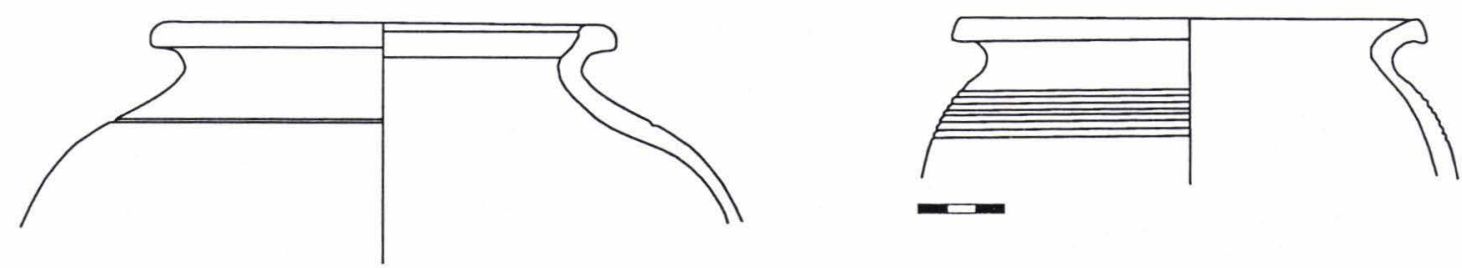

37.

38.
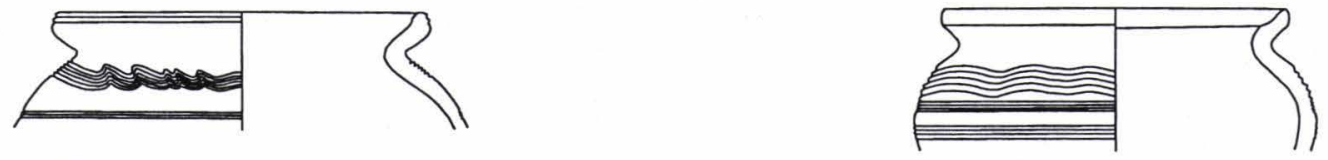

39.
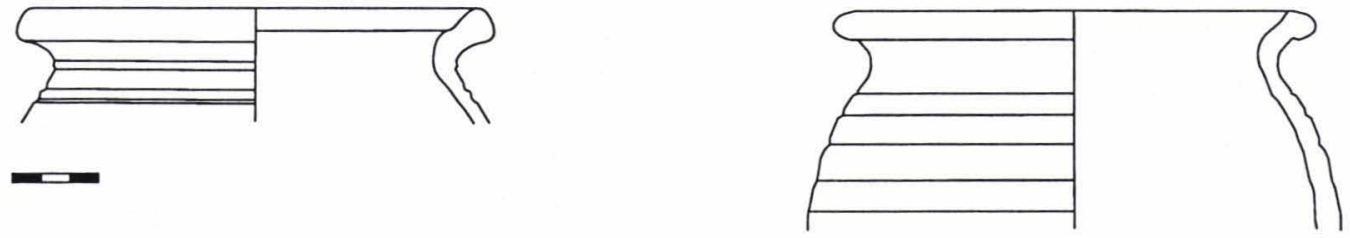

42.

43.
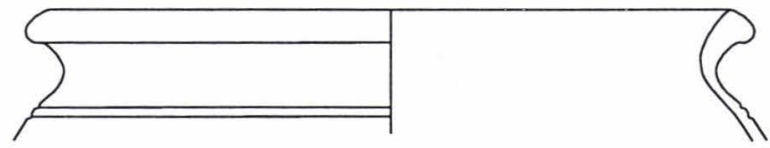

41.
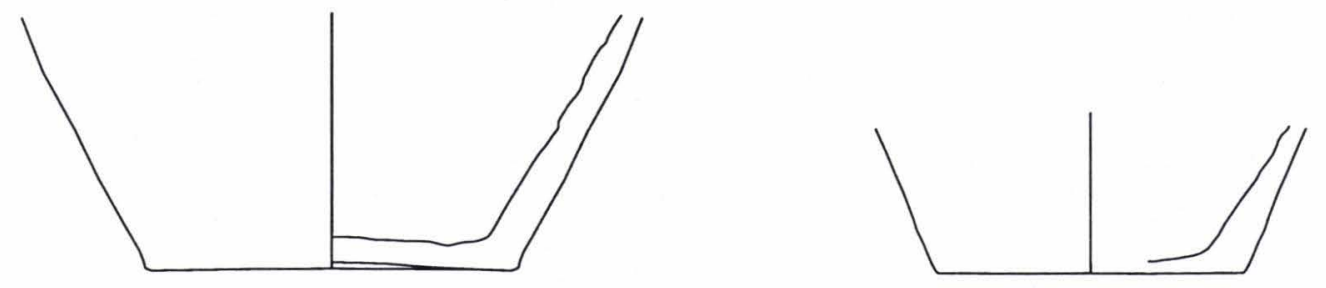

-

44.

45.
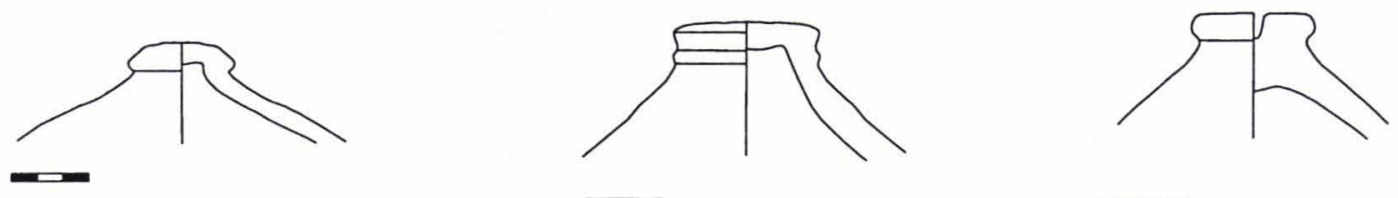

46.

47.

48.

Ceramică medievală: 37-45. Oale; 46-48. Capace 


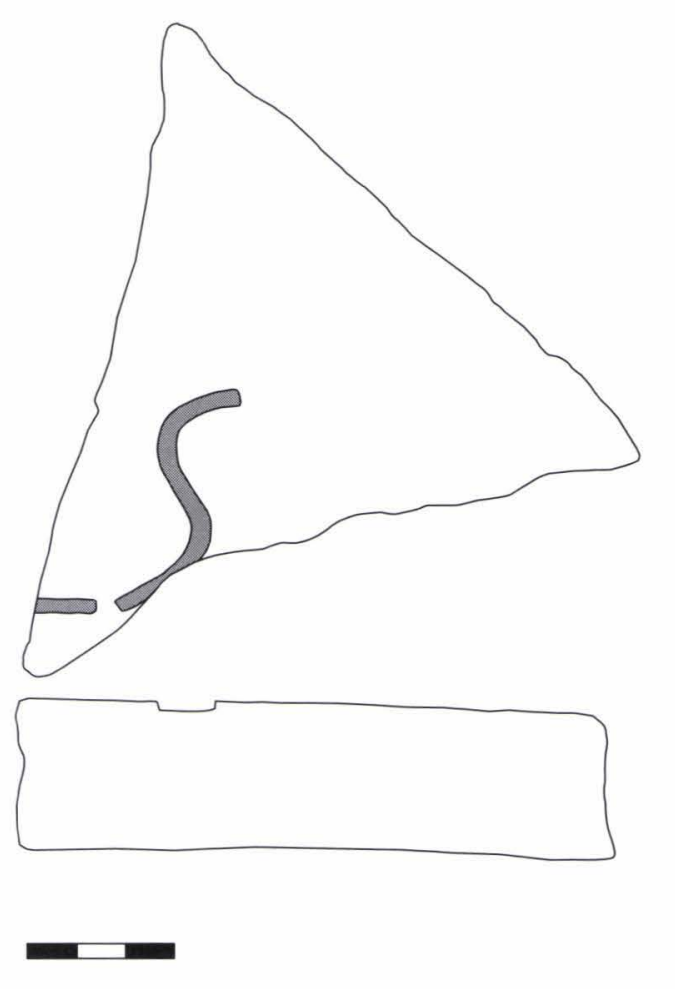

49.

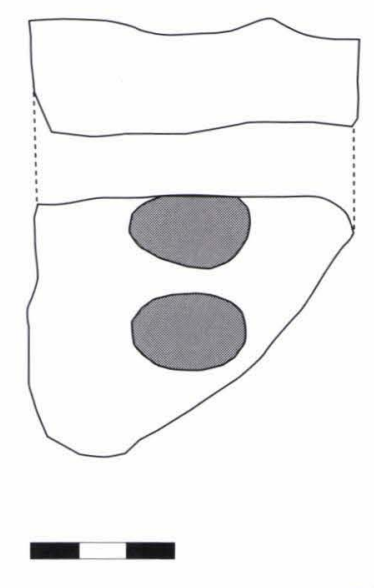

51.
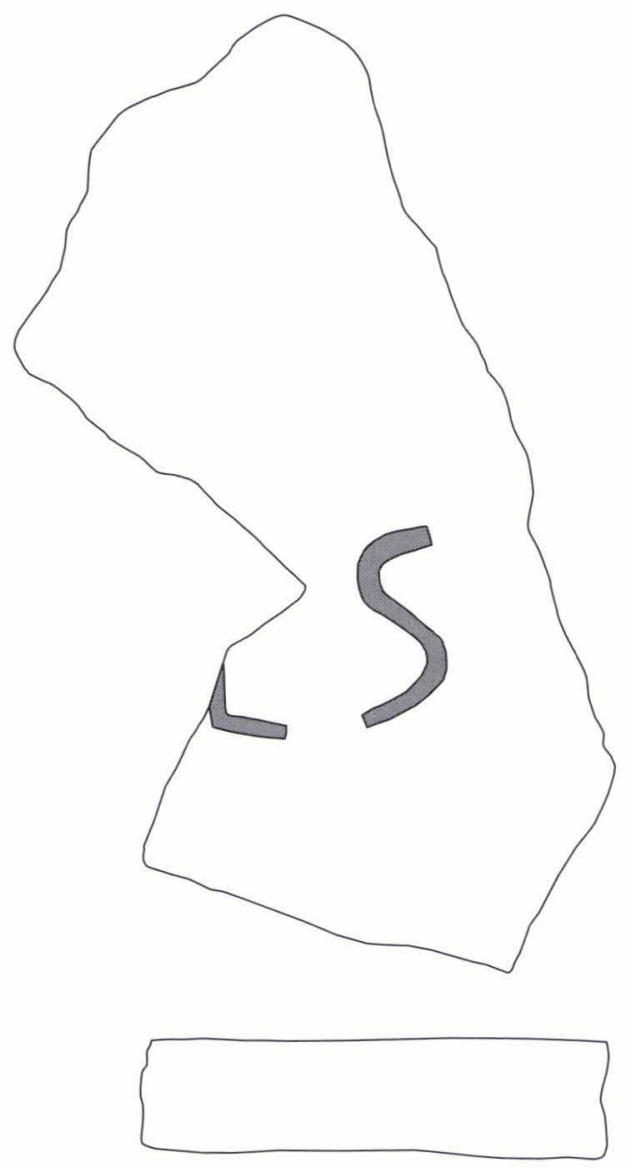

50.

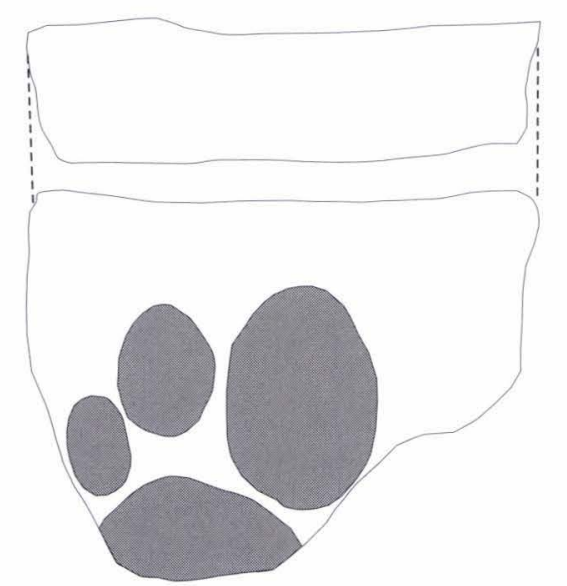

52.

PI. XIX 


$$
\begin{aligned}
& 1 \\
& 1 \\
& 1111
\end{aligned}
$$

